\title{
O ENSINO DE ENGENHARIA COMO UMA ATIVIDADE DE SERVIÇOS: A EXIGÊNCIA DE ATUAÇÃO EM NOVOS PATAMARES DE QUALIDADE ACADÊMICA
}

\author{
Ana Teresa Colenci
}

\begin{abstract}
Dissertação apresentada à Escola de Engenharia de São Carlos da Universidade de São Paulo, como parte dos requisitos para obtenção do título de Mestre em Engenharia de Produção.
\end{abstract}

Orientador: Prof. Dr. Renato Vairo Belhot

SÃO CARLOS

2000 
Aos meus pais e irmãos

por todo apoio e compreensão

neste árduo período 


\section{Agradecimentos}

Ao Prof. Dr. Alfredo Colenci Júnior, por todo estímulo e confiança e pelo exemplo oferecido.

Ao Prof. Associado Renato Vairo Belhot, amigo e orientador dessa dissertação, pelo destacado apoio e orientação no desenvolvimento do trabalho.

Aos professores da Área de Engenharia de Produção da EESC-USP, principalmente ao Prof. Dr. Edmundo Escrivão Filho e Prof. Dr. José Benedito Sacomano, pela ajuda fornecida na busca do conhecimento e inestimável apoio.

À amiga Nídia Pavan Kuri, pela orientação dada no processo de investigação.

Aos estimados José Luiz Chiaretto, Luiz Fernando Ferreira, Silvana e demais funcionários da Área de Engenharia de Produção da EESC-USP pelo apoio técnico.

Aos colegas e amigos Fábio, Mário, Ana Paula dos Reis, Ana Paula Marcheti e Nelma, pela amizade, apoio e pela oportunidade de convívio.

Ao Serviço de Biblioteca da EESC-USP, à amiga Teresinha das Graças Coletta e a Eleninha pela ajuda prontamente prestada na revisão das referências bibliográficas.

À Coordenadoria de Aperfeiçoamento Pessoal de Nível Superior - CAPES, pela bolsa de estudo concedida.

À Força Maior. 


\section{SUMÁRIO}

LISTA DE FIGURAS vii

LISTA DE TABELAS viii

RESUMO

$\begin{array}{ll}\text { ABSTRACT } & \mathbf{x}\end{array}$

1. INTRODUÇÃO

1.1. Formulação do problema 4

1.2. Objetivo do trabalho 6

1.3. Justificativa 6

1.4. Estruturação do trabalho 9

2. O ENSINO DE ENGENHARIA 11

2.1. Definições de engenharia 11

$\begin{array}{ll}\text { 2.2. O perfil do engenheiro } & 13\end{array}$

2.3. Histórico 15

2.4. Definições de engenheiro 18

2.5. O ensino de engenharia no Brasil 19

2.6. Situação atual $\quad 23$

2.7. Principais abordagens 26

2.8. $\mathrm{O}$ ensino de engenharia à imagem da manufatura: estratégias de desenvolvimento e critérios utilizados 35

2.9. Mudança de foco. O ensinar e o aprender 38 


\section{NOVAS EXIGÊNCIAS DE ATUAÇÃO ACADÊMICA NO CENÁRIO GLOBALIZADO

3.1. A mudança nas organizações e as organizações de aprendizagem 44

3.2. O momento atual 48

3.3. As novas habilidades $\quad 52$

3.3.1. O aprender a aprender 52

3.3.1.1. A importância da pesquisa 53

3.3.2. Flexibilidade $\quad 54$

3.3.3. Trabalho em grupo

3.4. Novas propostas de trabalho 59

3.4.1. Simulação e jogos 59

3.4.2. Aprendizagem baseada em problemas 60

3.4.3. Aprendizagem por descoberta 61

3.4.4. Aprendizagem Cooperativa e Ativa 62

4. A ÓTICA DE SERVIÇOS

4.1. O que é um serviço? $\quad 64$

4.2. Características dos serviços $\quad 68$

$\begin{array}{ll}\text { 4.3. Qualidade em serviços } & 71\end{array}$

4.3.1. Avaliação da qualidade em serviço 73

4.3.2. Momentos da verdade $\quad 75$

4.4. Modelos da qualidade em serviços $\quad 79$

4.4.1. O modelo de Gummesson $\quad 80$

4.4.2. O modelo de Gronroos 82

4.4.3.O modelo de Gummesson \& Gronroos 83 
4.4.4. O modelo da qualidade em serviços de Parasuraman, Zeithalm \& Berry 84

4.5. As dimensões da qualidade em serviços e os níveis de tolerância do consumidor

5. UMA ESTRUTURA DE REFERÊNCIA PARA INVESTIGAR A QUALIDADE NO ENSINO DE ENGENHARIA SOB A ÓTICA DE SERVIÇOS

5.1. A qualidade do ensino de engenharia

5.2. O ensino de engenharia sob a ótica de serviços

5.2.1. O projeto pedagógico

98

5.3. A estrutura de referência proposta

98

5.3.1. Adaptação do modelo nos diferentes níveis

6. CONSIDERAÇÕES FINAIS

6.1. Perspectivas Futuras

REFERÊNCIAS

122

BIBLIOGRAFIA COMPLEMENTAR 


\section{LISTA DE FIGURAS}

Figura 1. A Formação do Engenheiro Voltada para Demandas Futuras e Temporais 7

Figura 2. Gap Educacional

Figura 3. Comparação Evolutiva Entre Processos de Produção e Processos Educacionais

Figura 4. A Visão Tradicional do Processo Educacional à Semelhança do Processo de Produção

Figura 5. Grupo de Aprendizagem 58

Figura 6. Contínuo Entre Produtos e Serviços

Figura 7. Avaliação da Qualidade em Serviços

Figura 8. Ciclo de Serviços Para um Supermercado

Figura 9. Modelo de Gummessom

Figura 10. Modelo da Qualidade de Serviço de Groonroos

Figura 11. Modelo da Qualidade em Serviços de Groonros-Gummesson

Figura 12. Modelo da Qualidade em Serviço de Parasuraman, Zeithalm e Berry

Figura 13. Níveis de Expectativas dos Serviços

Figura 14. Diferentes níveis de relações de prestação de serviços na educação.

Figura 15. Adaptação do Modelo da Qualidade em Serviço para o nível estratégico

Figura 16. Adaptação do Modelo da Qualidade em Serviço para o nível tático 106

Figura 17. Adaptação do Modelo da Qualidade em Serviço para o nível operacional 


\section{LISTA DE TABELAS}

Tabela 1. Diferentes Enfoques do Processo Educacional

Tabela 2. Aspectos da Analogia Entre Ensino Superior e Processo de Produção em Massa

Tabela 3. A Educação Como uma das Manifestações de Serviço 


\section{RESUMO}

COLENCI, A. T. (2000). O ensino de engenharia como uma atividade de serviços: a exigência de atuação em novos patamares de qualidade acadêmica. São Carlos, 2000; 131p. Dissertação (Mestrado) - Escola de Engenharia de São Carlos. Universidade de São Paulo

Atualmente, com a globalização da economia e a alta competitividade imposta por mudanças sociais, reforça-se de maneira inigualável a necessidade de se equacionar a questão da capacitação humana no que se refere à qualificação profissional frente às novas exigências. Essa necessidade é imposta pelos desafios diante de uma atuação competente estabelecida por novos padrões de qualidade e produtividade como única forma de atuação competitiva. Novos padrões de desempenho do trabalho, apoiados em critérios de multidisciplinaridade do conhecimento e multifuncionalidade de competências passam a ser exigidos não só dos produtos e serviços mas dos profissionais de engenharia, enquanto agentes de transformação tanto sociais como mercadológicas. Neste trabalho, abordam-se aspectos relativos à situação do ensino de engenharia e às novas exigências de atuação no cenário globalizado com o objetivo de propor uma estrutura de referência que permita avaliar a qualidade do ensino de engenharia em seus vários aspectos.

Palavras-chave: ensino de engenharia, serviços, qualidade 


\begin{abstract}
COLENCI, A. T. (2000). The teaching of engineering as a service activity: the necessity of performance in new ranks of academic quality. São Carlos, 2000; 131p. Dissertação (Mestrado) - Escola de Engenharia de São Carlos. Universidade de São Paulo.

Nowadays, due to economy globalization and the high competitivity impose by social changes, the necessity of solving the question of human capacity concerning professional qualification facing the new exigencies is reinforced. Such necessity is imposed by the challenges of a competent performance established by new quality and productivity patterns as the only way of competitive performance. New patterns of performance at work based on criteria of multidisciplinarity of competences start to be required not only from products and services, but also from engineering professionals, while agents of social and market transformations. The present paper deals with the aspects concerning the engineering teaching situation and the new exigencies of performance in the globalized background in order to propose a reference structure witch allows evaluating the quality of engineering teaching in its several aspects.
\end{abstract}

Keywords: engineering education, service, quality 


\section{CAPÍTULO 1}

\section{INTRODUÇÃO}

A cada momento a sociedade mundial vem sofrendo sensíveis mudanças nos ambientes político, econômico e social por força do movimento hegemônico dos países desenvolvidos. No início do século falava-se em Revolução Industrial, caracterizada pelo desenvolvimento de novas indústrias e com o passar do tempo, o foco das atenções passou a ser o processo de inovação tecnológica, como um dos alavancadores do crescimento das empresas industriais.

Atualmente, uma nova realidade está sendo dinamicamente vivenciada. Com o setor secundário praticamente já delineado e com o início de uma nova onda baseada na informação e no conhecimento, emerge uma sociedade com a economia caracteristicamente apoiada no setor terciário, no qual as organizações com foco em serviços ganham maior relevância.

Assim, o processo de inovação tecnológica reforça sua importância de participação no panorama político-econômico e social, merecendo um tratamento endógeno no ambiente das organizações - quando incorporado no comportamento das equipes e no tratamento dos processos organizacionais e, com igual importância, um tratamento exógeno - quando incorporado estrategicamente nos produtos, de 
modo a garantir sua diferenciação e através dela, uma confortável situação monopolista às organizações industriais ou de serviços.

Paralelamente a este cenário em profunda mudança, cabe à universidade posicionar-se diante deste processo e frente às reais necessidades de seus clientes internos e externos, beneficiários da pesquisa e da prestação de serviços. Em particular, a preocupação e as ações em direção à melhoria da qualidade do ensino de engenharia vêm crescendo de forma significativa, o que tem ensejado inúmeros especialistas a buscar novas estratégias para o processo educacional. Um dos aspectos que leva à busca por um novo modelo para o processo de ensino e de aprendizagem é o marcante descompasso existente entre ensino praticado e o estágio atual de desenvolvimento tecnológico caracteriza a real demanda do mercado por profissionais qualificados. Desses profissionais espera-se que possam ter uma atuação competente, ao nível do estado da arte do conhecimento existente e que possam enfrentar e resolver os problemas atuais e futuros da sociedade. Sob este ponto de vista, pode-se constatar, sem grande dificuldade, que a universidade vem apresentando lacunas em sua estrutura de gestão acadêmica e no seu modelo educacional, que devem ser corrigidas depois de amadurecida discussão.

Numa sociedade em acelerado processo de mudança, conforme já salientava DRUCKER (1968), numa antevisão que se confirmou de maneira indiscutível, que aquele antigo modelo em que era preciso ir à escola para se ter acesso ao conhecimento, está sofrendo revisões profundas. O aluno de hoje não sente a dificuldade de acessar esse conhecimento, mas tem de compreendê-lo, assimilando-o até o estágio de domínio, para a seqüente difusão. O modelo transmissão-recepção já não é, em si, tão eficiente uma vez que não desenvolve as habilidades essenciais 
requeridas de um profissional, entre elas a própria aprendizagem contínua. Hoje em dia, segundo RIVAS (1998), a necessidade da aprendizagem contínua tem sido reforçada, até mesmo pela freqüência com que os profissionais têm mudado de atividade funcional ou mesmo, de profissão. Esse fato também pode ser reforçado, se for levado em consideração que o conhecimento desenvolvido nos últimos trinta anos superou praticamente, todo o conhecimento anteriormente desenvolvido pela humanidade (BELHOT 1997).

O modelo transmissão-recepção, torna-se obsoleto na medida em que faz apenas com que os alunos sejam receptáculos de conhecimento. Segundo DEMO (1999), não dá para se reproduzir cultura, o ser humano só aprende na condição de sujeito, fazendo sua própria história. A aprendizagem é atividade social e cultural e o professor tem papel importante neste aspecto, não como simples repasse do conhecimento como o faz no modelo transmissão-recepção mas como processo reconstrutivo. O papel do professor não é o de pensar pelo aluno e sim o de fazer o aluno pensar, pensando juntos e assim reconstruindo.

O desafio em termos de qualidade do ensino de engenharia está baseado em buscar um novo modelo que incorpore as mudanças tecnológicas e sociais e ofereça alternativas que valorizem o processo de ensino-aprendizagem.

Desta forma, o ensino de engenharia não vai estar atendendo somente às necessidades do mercado mas também da própria sociedade que, segundo MELLO (1998), espera dos profissionais: inteligência e conhecimento adaptados a um novo perfil profissional; qualificação profissional para o exercício da cidadania; capacidade de lidar com novos parâmetros de difusão de conhecimentos dados pela 
informática e meios de comunicação de massa e contribuição para recuperar/construir a dimensão social e ética do desenvolvimento econômico.

Há, neste caso, a emergente necessidade de se implementar a premissa baseada no aprender a aprender e conseqüentemente, de se buscar um outro modelo que permita a articulação do aprendizado sob o atual quadro de influências.

Esse novo modelo alternativo pode ter suas bases na educação vista como uma atividade de serviços e presume a mudança do enfoque estrutural e metodológico hoje centrado no ensino, para centrar-se na aprendizagem considerando questões relativas à caracterização dos clientes (beneficiários), aos papéis e posturas dos novos agentes e atores: a instituição e seu modelo de gestão acadêmica, o docente e seus alunos e, a indispensável avaliação de desempenho como fonte de retroalimentação do sistema no ensino de engenharia.

\subsection{FORMULAÇÃO DO PROBLEMA}

Desde algum tempo, a preocupação com o ensino, e especificamente com o ensino de engenharia, vem aumentando no meio acadêmico. Isso ocorre porque ao se formar e ingressar no mercado de trabalho, o profissional precisa ser treinado para compatibilizar a realidade em diferentes níveis de interpretação. As necessidades da sociedade também têm sofrido constantes mudanças, solicitando desses engenheiros, soluções criativas e diferentes das já conhecidas. Isso significa que "novas soluções” devem ser buscadas para os "novos problemas”. Essas afirmações podem ser reforçadas pelos numerosos artigos que vêm sendo anualmente publicados no 
Congresso Brasileiro de Ensino de Engenharia - COBENGE e nas revistas internacionais que tratam da educação em engenharia. Esses pesquisadores da questão do ensino, têm discutido suas preocupações e apresentado os resultados obtidos nas diferentes áreas da engenharia.

Segundo BELHOT (1997), nesta época de mudanças sociais, a tecnologia está exercendo um papel primordial no ensino. Entre as diversas questões que poderiam ser levantadas, uma parece crucial: o ciclo de vida. O ciclo de vida da tecnologia que por ser cada vez mais curto, cria dificuldades para o processo educacional, que passa a ter problemas para incorporá-las, pois elas ocorrem mais rapidamente que sua absorção pelo ambiente educacional. Além disso, a valorização dos recursos humanos tem propiciado o surgimento de novos conceitos que ajudam a vencer as dificuldades atuais. É o caso das múltiplas inteligências (GARDNER 1995), do aprendizado ativo e cooperativo, dos novos requisitos profissionais, como trabalho em equipe, criatividade, iniciativa e flexibilidade, que precisam ser incorporados à formação do engenheiro, para que ele aprenda a "lidar com o novo" e não mais reproduzir soluções conhecidas.

A considerar o ensino de engenharia, sob o modelo atual, que sofreu pequenas alterações ao longo do tempo, já se pode perceber um descompasso entre “o que se oferece” e “o que é solicitado” em termos de atuação profissional do engenheiro. Se essa situação se perpetuar, maior será o descompasso entre a formação e a atuação profissional do engenheiro e menor será a qualidade final obtida no processo de ensino-aprendizagem.

Sob este aspecto, surge a necessidade de se analisar o processo de ensino e de aprendizagem à luz dessa nova realidade, buscando um novo enfoque que seja capaz 
de identificar os problemas existentes, explicar as circunstâncias atuais e propor mudanças.

Dessa forma, o problema a ser investigado caracteriza-se pela busca das respostas às questões: Que instrumentos de análise seriam adequados para apontar as deficiências do atual modelo de ensino de engenharia e o que pode ser feito para melhorá-lo qualitativamente?

\subsection{OBJETIVO DO TRABALHO}

Este trabalho tem por objetivo propor uma estrutura de referência, a partir da ótica de serviços, que permita identificar os princípios e estratégias que dão sustentação ao atual modelo de ensino de engenharia e estabelecer mecanismos que possam incrementar a qualidade na educação em engenharia, face às restrições hoje impostas.

As circunstâncias que ensejaram a realização deste trabalho, a seguir, se estabelecem.

\subsection{JUSTIFICATIVA}

Segundo MELLO (1998), a educação hoje é uma prioridade visada em todo o mundo. Diferentes países, de acordo com suas características, desenvolvem reformas em seus sistemas educacionais, com a finalidade de torná-los mais eficientes e 
eqüitativos no preparo de uma nova cidadania, capaz de enfrentar a revolução tecnológica que está ocorrendo no processo produtivo e seus desdobramentos políticos, econômicos sociais e éticos.

Torna-se evidente que o conhecimento, a capacidade de processar e selecionar informações, a criatividade e a iniciativa são essenciais para o desenvolvimento e para a modernidade. Pode-se dizer que habilidades cognitivas e competências sociais de grau superior, tais como flexibilidade, autonomia, capacidade de adaptação a novas situações, são prioridades até em países de terceiro mundo como o Brasil, que apresenta deficiências em demandas mais básicas como o ensino básico (MELLO 1998).

Em termos educacionais, há a necessidade de se pensar em um novo perfil profissional qualificado para se ter qualidade e produtividade a fim de, conseqüentemente, alcançar a competitividade.

A Figura 1 aponta as necessidades de mudança do perfil profissional. “A escola que estiver preparando o estudante para memorizar informações está criando um candidato ao desemprego” DIMENSTEIN (1998).

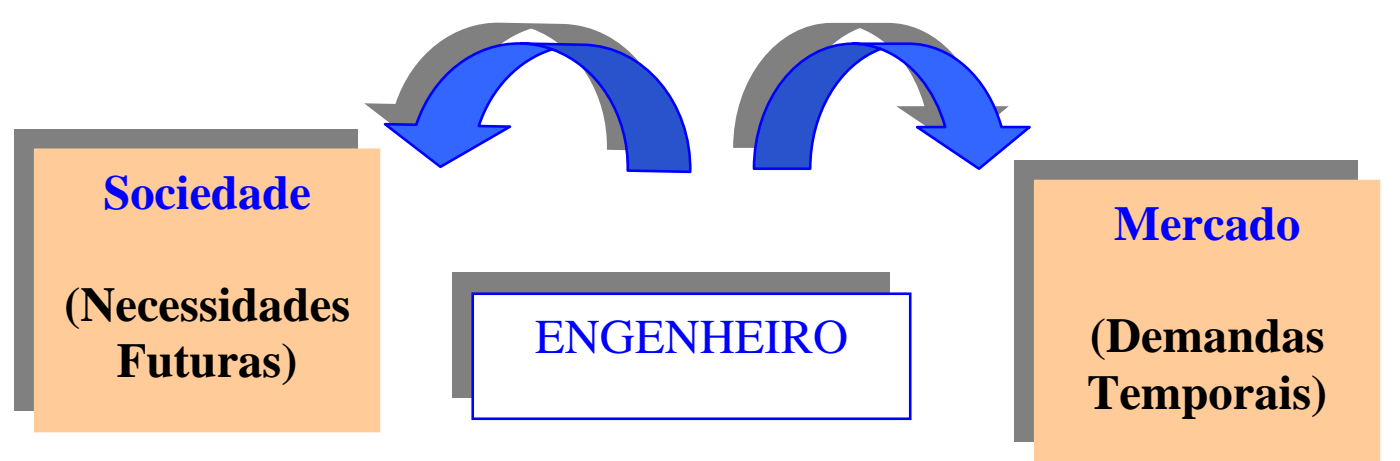

FIGURA 1. A formação do engenheiro voltada para demandas futuras e temporais. 
Conforme aponta a Figura 1, a formação do engenheiro consiste em preparálo para necessidades de curto e de longo prazo. Voltando-se para a sociedade, a formação do engenheiro deve estar ligada à sua própria cidadania, a formação do profissional como ser social, como parte integrante de uma comunidade, em contrapartida à formação do profissional para o mercado pois, devido ao grande avanço tecnológico, este se depara constantemente com problemas com os quais nunca lidou antes. A universidade tem, neste caso, o papel de formá-lo para trabalhar com problemas que ainda não ocorreram, para lidar com o novo. É nesse aspecto que a preocupação com a qualidade do ensino de engenharia vem ganhando maior importância.

Por meio de programas como o PAIUB - Programa de Avaliação Institucional das Universidades Brasileiras, (MEC-SESU, 1994), o Projeto CRE-Columbus e mais recentemente o Education Pilot Criteria, uma extensão do The Malcom Baldrige National Quality Award (BALDRIGE E AWARD, 1995) acham-se disponíveis diversos sistemas de avaliações institucionais, que criam projetos e programas para avaliar a qualidade de cursos de graduação em diversas universidades. Por meio destes programas, constata-se que há movimentos no sentido de melhorar a qualidade no ensino. Esses movimentos, no entanto, tornam-se parciais por não fazerem parte de uma sistematização de variáveis.

Na Engenharia, foco em estudo, um dos princípios fundamentais de sua atividade é a sistemática busca pela otimização de resultados. Entretanto, ao fixar-se a atenção para um dos pontos basilares que é o Ensino de Engenharia, pode-se perceber que o esforço feito para atingir os melhores resultados está longe de 
merecer um tratamento sistêmico e objetivamente coordenado. Esse fato, por si, é revelador e de grande importância, uma vez que através do ensino de engenharia, vão se nuclear e reproduzir conceitos, competências e habilidades, enfim elementos formadores da efetiva capacitação e da cultura tecno-organizacional.

Frente a essa mudança de perfil, enfoca-se a qualidade do ensino de engenharia que, por ser fator essencial e de suma importância para a formação do profissional, deve ser melhor estudada com a finalidade de se buscar melhores resultados.

Nesse sentido, com a compromissada busca por melhores resultados procurou-se dar um tratamento sistêmico ao ensino de engenharia e oferecer uma contribuição relevante já que se trata de um assunto pertinente e de suma importância para a formação do engenheiro.

\subsection{ESTRUTURAÇÃO DO TRABALHO}

A dissertação está dividida em seis capítulos. O conteúdo deles é dado a seguir.

O capítulo 1, que é este, faz a introdução do assunto, apresenta os objetivos e as justificativas para a realização do trabalho.

O capítulo 2, aponta as definições de engenharia, faz um breve histórico, apresenta a situação atual do ensino de engenharia e finaliza fazendo uma analogia do ensino de engenharia com a manufatura. 
O capítulo 3, discorre sobre as novas exigências de atuação acadêmica no cenário globalizado e frisa as novas tendências do ensino e novas habilidades requeridas do profissional, como o aprender a aprender, a flexibilidade de se adaptar a novas mudanças e a necessidade de trabalhar em equipe.

O capítulo 4, propicia um melhor entendimento da atividade de serviços, apresentando suas características, os tipos, avaliação, momentos da verdade critérios de avaliação, qualidade total e mesmo o marketing de serviços e apresenta os modelos de referência de qualidade em serviços, passando pelos principais aspectos apontados na literatura.

O capítulo 5, demonstra o ensino de engenharia sob a ótica de serviços e propõe uma estrutura de referência para avaliar a qualidade do ensino de engenharia tal qual se encontra.

O capítulo 6, por fim, aponta as considerações finais do trabalho e propõe a possibilidade de novas investigações. 


\section{CAPÍTULO 2}

\section{O ENSINO DE ENGENHARIA}

\subsection{Definições de engenharia}

Encontra-se na literatura, as mais diversas definições de engenharia. PLONSKI (1993) afirma que há três definições formais disponíveis sobre o conceito de engenharia, uma formal estrangeira, uma legal brasileira e uma preocupada com o vínculo tecnológico entre pesquisa, engenharia, fabricação e consumo.

Com relação à definição formal estrangeira, o "Engineers Council for Professional Development” dos EUA, caracteriza a engenharia como “a aplicação criativa de princípios científicos ao projeto de desenvolvimento de estruturas, máquinas, dispositivos ou processos de fabricação; ou à construção e/ou operação dos mesmos com perfeito conhecimento de seu projeto; ou à predição do seu comportamento sob condições determinadas de operação; todos os aspectos anteriores no que se refere: à função prevista, à economia da operação e à segurança das pessoas e bens envolvidos”.

A definição legal brasileira, está explícita na Lei $n^{0}$ 5.194/66, que regula as profissões de engenheiro, arquiteto e engenheiro agrônomo. Esta lei, estabelece, em 
seu artigo $7^{\circ}$, as atividades e atribuições destes profissionais. Entre elas estão “o planejamento ou projeto em geral de regiões, zonas, cidades, obras, estruturas, transportes, exploração de recursos naturais e desenvolvimento da produção industrial e agropecuária; fiscalização, direção e execução de obras e serviços técnicos; e, produção técnica especializada, industrial ou agropecuária”.

O terceiro conceito que é o que vincula tecnologia com pesquisa, engenharia, fabricação e consumo, define engenharia como “o elemento que transforma tecnologia, ciência, bens e homem em tecnologia. Usando expressões tradicionais, engenharia produz tecnologia por meio de homens que se utilizam de equipamento, materiais, ciência e tecnologia existentes. (...) da engenharia resulta tecnologia e conhecimento não registrado no homem” PLONSKI (1991).

Estas definições não se excluem, apenas cada uma enfatiza um ponto, perspectivas diferentes. A primeira enfatiza o conteúdo da atividade do engenheiro e da engenharia. A segunda, focaliza a função econômica e social da engenharia e a terceira situa a engenharia num modelo geral de interesse dos estudiosos das questões relacionadas à política científica e tecnológica voltadas para a engenharia.

SILVA (1997) encontrou trinta e cinco definições e apontou engenharia como “a arte profissional de organizar e dirigir o trabalho do homem aplicando conhecimento científico e utilizando, com parcimônia, os materiais e as energias da natureza para produzir economicamente bens e serviços de interesse e necessidade da Sociedade dentro dos parâmetros de segurança”.

Segundo o autor, uma definição formal, clara e objetiva contribui para que as referidas fronteiras sejam melhor identificadas, auxilia na definição de matérias 
pedagógicas essenciais para compor um currículo mínimo de referência para cursos de Engenharia, tornando mais claro o perfil do profissional que deve, acima de tudo, ser um agente transformador da Sociedade.

\subsection{O perfil do Engenheiro}

Sendo o Engenheiro o objeto deste estudo, cabe uma reflexão sobre a caracterização do seu perfil, de modo a ressaltar as potencialidades a serem demandadas ao longo de seu desempenho.

A definição clássica relaciona o Engenheiro como o indivíduo que procura colocar as forças da natureza e seus recursos a serviço do homem. Entretanto, modernamente, o engenheiro é visto como o indivíduo que busca continuamente ampliar seus conhecimentos, destrezas e aptidões técnicas, de comunicações e relações humanas, a fim de contribuir com o desenvolvimento global da sociedade, em harmonia com o meio ambiente, através da teorização, do desenvolvimento e produção de processos, estruturas e máquinas de valor prático e econômico.

COLENCI JR. (1996) apresenta uma importante contribuição ao estabelecer tais potencialidades. São elas:

- Capacidade de reconhecer problemas e solucioná-los;

- Ampla base científica e um profundo conhecimento de especialização;

- Domínio da matemática e das ciências físicas e biológicas;

- Capacidade de comunicar suas idéias e defender seus projetos; 
- Alto sentido ético, social e responsabilidade profissional;

- Mentalidade aberta e atitude positiva diante da vida;

- Autodidatismo;

- Ampla cultura e curiosidade por novos conhecimentos;

- Domínio de linguagens computacionais;

- Domínio de língua estrangeira;

- Bases de gerência e bom relacionamento humano.

Pode-se estabelecer de maneira simplificadora que o engenheiro é o "produto ideal e complexo” da organização de ensino a quem podem ser atribuídos: imagem (embalagem e rotulação) e conteúdo (comportamento, competência, presença social) e dessa forma, ser passível de um tratamento holístico.

Como se pode notar, as preocupações se estendem além do aspecto cognitivo, abrangendo os aspectos comportamentais e atitudinais. A preocupação pela formação do engenheiro deve-se estender muito além do "know how" (como fazer) e do "know why" (por que fazer) para oferecer o "skill” (habilidade) e o "feeling" (sensibilidade) no domínio e aplicação do conhecimento. Pode-se dizer que o Engenheiro terá sua competência reconhecida e será remunerado por isso, na medida em que, com habilidade e sensibilidade puder transformar conhecimento em soluções úteis para a empresa. 


\subsection{Histórico}

Desde os primórdios, há uma busca incessante por novas técnicas e tecnologias. Segundo BAZZO \& PEREIRA (1997), as técnicas primitivas tiveram origem com a descoberta da alavanca, no domínio do fogo, no polimento das pedras e no cozimento dos alimentos, conhecido também como período Paleolítico. No período seguinte, o Neolítico, há cerca de 6 mil anos, as modificações culturais ocorreram devido à introdução da agricultura, da domesticação de animais, da modelagem cerâmica e da fabricação de vinho e cerveja. Passando-se ainda pelas idades da pedra lascada, da pedra polida e dos metais, chega-se à tecnologia como é hoje entendida.

Segundo TELLES (1984), pode-se dizer que a engenharia científica só teve início quando se começou a chegar a um consenso de que tudo aquilo que se fazia em bases empíricas e intuitivas era, na realidade, regido por leis físicas e matemáticas, as quais era necessário descobrir e estudar. Leonardo Da Vinci e Galileu, nos séculos XV e XVII, podem ser considerados os precursores da engenharia científica. Da Vinci fez a primeira tentativa de aplicar a estática para a determinação de forças atuando em uma estrutura simples, ou seja, a primeira aplicação da matemática à engenharia estrutural. Esses estudos nunca foram publicados e permaneceram ignorados por séculos. Galileu publicou, em 1638, o famoso livro As Duas Novas Ciências, que trata da resistência de vigas e de colunas, sendo assim o primeiro livro, em todo o mundo no campo da resistência dos materiais. 
Ainda segundo o autor, deste tempo em diante, a engenharia foi se estruturando e no século XVIII foi possível chegar-se a um conjunto sistemático e ordenado de doutrinas que constituíam a primeira base teórica da engenharia.

A engenharia moderna nasceu dentro dos exércitos. A descoberta da pólvora e depois o processo de artilharia obrigaram a uma completa modificação nas obras de fortificação que, principalmente a partir do século XVII, passaram a exigir profissionais habilitados para o seu planejamento e execução.

A necessidade de realizar obras, que fossem ao mesmo tempo sólidas e econômicas e, também estradas, pontes, portos para fins militares forçou o surgimento dos oficiais-engenheiros e a criação de corpos especializados de engenharia nos exércitos.

TELLES (1984) afirma que, pelos padrões atuais, a maioria destes oficiais não poderia ser considerada engenheiro uma vez que nessa época poucos eram os cursos onde se ensinasse algum assunto relacionado à engenharia, mas no BrasilColônia eram esses oficiais os únicos que tinham algum conhecimento de engenharia e passaram a construir não apenas fortificações mas também palácios, igrejas, conventos, aquedutos etc.

Ainda segundo TELLES (1984), em 1795, funda-se em Paris, por iniciativa de Gaspard Monge e de Fourcroy, a famosa École Polytechnique, que se tornou o modelo de escolas posteriores. Essa escola tinha o curso elaborado em três anos, onde professores de alto nível ensinavam as matérias básicas da engenharia, sendo os alunos depois encaminhados a outras escolas especializadas: Ponts et Chausseés, École des Mines etc. 
O nascimento da engenharia moderna, ou da engenharia propriamente dita, coincidiu também com a Revolução Industrial e o Iluminismo, ocorridos no século XVIII. A Revolução Industrial, com o aparecimento da máquina a vapor, e de uma série de outras máquinas, forçou o desenvolvimento tecnológico e o estudo e pesquisa das ciências físicas e matemáticas, tendo em vista as suas aplicações práticas, isto é, da própria engenharia. O movimento do Iluminismo libertou o espírito humano dos estreitos limites da educação formal e valorizou a observação da natureza, a experimentação, o estudo das ciências físicas e naturais e suas aplicações, tendendo a terminar com o desprezo e a situação de inferioridade a que eram relegadas as chamadas artes mecânicas, desde a Idade Média. Esses dois movimentos promoveram a mudança completa da mentalidade científica, que passaram de mera especulação a investigações profundas passando a ter sentido nas aplicações práticas.

SACADURA (1999), atribui os moldes da profissão do engenheiro às três grandes revoluções industriais.

A Primeira Revolução Industrial foi a que começou na Inglaterra no final do séc. XVIII, com o desenvolvimento da máquina a vapor, à qual se deve o início da industrialização. Foi nesta época que se esboçou o papel social e econômico da engenharia, com a vontade de reduzir, pelo uso da máquina, o da força humana e o custo da mão de obra.

A Segunda Revolução Industrial, foi a que atingiu uma área do mundo mais extensa que a primeira, incluindo países mais avançados, como EUA. Começou com o uso do petróleo e do gás como fontes de energia, por volta de 1880. Tiveram destaque no desenvolvimento de técnicas modernas de produção industrial. Taylor lança nesta época os fundamentos da organização e do gerenciamento da produção 
industrial que se tornariam brevemente ferramentas básicas da profissão do engenheiro do século XX, com suas habilidades de gerente e administrador. Também através desta revolução, pode-se perceber a introdução de um relacionamento entre pesquisa científica e indústria.

A Terceira Revolução Industrial começou na segunda metade do século XX (a qual ainda prospera) com a introdução de aplicações da física quântica, da informática e da eletrônica, que permitiram as chamadas, novas tecnologias de comunicação que impulsionaram a globalização da economia em nível mundial.

Ainda segundo SACADURA (1999), durante todo o século XX, os engenheiros sempre foram privilegiados pela expansão tecnológica. Deste modo, a profissão do engenheiro recebeu considerável impulso tanto na carreira como no aparecimento de novas especialidades de engenharia, novas competências exigidas pelo mercado de trabalho e novas funções exigidas. Essa evolução foi, de maneira geral, acompanhada da intensificação do papel econômico e social do engenheiro.

TELLES (1984) afirma que no Brasil e em Portugal estes efeitos só se fizeram sentir depois de um longo tempo devido à dificuldade de comunicação.

\subsection{Definições de Engenheiro}

Com relação ao termo engenheiro, o título dado aos primeiros engenheiros militares era de oficial de engenheiros, e não oficial-engenheiro ou simplesmente engenheiro, o que dava a entender que todos os subalternos e soldados eram considerados engenheiros porque também se dedicavam a fazer obras. Da mesma 
forma, era usada a expressão batalhões de engenheiros, denominação mantida no Brasil até o início do século atual, segundo TELLES (1984).

Além disso, este mesmo autor salienta que o termo engenheiro já era usado desde o século XVII, tanto em português como em algumas outras línguas, com o sentido de quem é capaz de fazer fortificações e engenhos bélicos. A função do engenheiro era também confundida com a do arquiteto e a do construtor. Não havia uma diferenciação na terminologia das profissões.

Em inglês o termo engineer, tem também o sentido de maquinista, ou de mecânico.

Segundo SACADURA (1999), os conceitos de "engenheiro" ou "engenho" teriam suas origens na Europa da Renascença. Seriam derivados da palavra latina ingenium, que significava gênio, talento criativo, potencial inventivo. Com essa definição, a engenharia entrou desde o início no círculo restrito das artes que, segundo a tradição humanística daquela época, implicavam em eloqüência, poesia e mais tarde, arquitetura.

\subsection{O ensino de engenharia no Brasil}

BAZZO \& PEREIRA (1997), afirmam ser difícil estabelecer o início da atividade de engenharia no Brasil, mas que começou efetivamente com as primeiras casas dos colonizadores e com a construção de muros e fortins. O desenvolvimento da engenharia manteve-se atrasado por muito tempo pelo fato da economia estar 
baseada na escravidão, o que implicava na proibição da instalação de indústrias no Brasil.

TELLES (1984) afirma que o primeiro documento oficial conhecido, referente à formação de engenheiros é a carta régia de 15/01/1699, de D. Pedro II de Portugal ao governador do Rio de Janeiro, determinando a criação de uma aula de fortificação, "para que assim possa nessa mesma conquista haver engenheiros". Notese que paisanos podiam seguir aquela aula, que preparava, conjuntamente, engenheiros militares (ou fortificadores) e artilheiros. O ensino era certamente precário e não se conhecem programa e duração dos estudos.

Foi em 1810 a fundação da Academia Real Militar, de onde descende a famosa Escola Polytechnica do Rio de Janeiro considerada como o início do ensino de engenharia no Brasil.

Os antecedentes mais antigos da engenharia brasileira são de Portugal. Em Lisboa, já havia desde o século XVI, a aula de Esfera, na Escola de Santo Antão, onde se ensinava matemáticas aplicadas às fortificações (engenharia) e à navegação. Esse curso pode ser considerado o antecedente mais remoto do ensino de engenharia em Portugal e no Brasil, conforme TELLES (1984).

No Brasil, a referência mais antiga é a contratação por volta de 1649, do holandês Miguel Timermans, “engenheiro de fogo”, que aqui esteve de 1648 a 1650, encarregado de formar discípulos aptos para os trabalhos de fortificações, segundo TELLES (1984), e mais, apresenta uma importante cronologia:

Em 1694, registrou-se o envio para o Brasil do capitão-engenheiro Gregório Gomes Henriques para ensinar os artilheiros do Rio de Janeiro. 
Em 1699, foi criada uma Aula de Fortificação no Rio de Janeiro e, em 1710, uma Aula de Fortificação e Artilharia em Salvador.

Em 1719, havia no Recife uma aula de Fortificação. E em 1767, a aula do Rio de Janeiro sofre transformações e passa a se denominar Aula do Regimento de Artilharia do Rio de Janeiro. Em 1792, a aula do Rio de Janeiro é radicalmente remodelada pelo governador deste Estado, D. José Luís de Castro, $2^{\circ}$ conde de Resende, que instituiu a Real Academia de Artilharia, Fortificação e Desenho. O curso também aberto a particulares, era de seis anos, o último dos quais obrigatório para “os que quiserem seguir a profissão de engenheiro” e se lecionava engenharia civil (que a época se denominava arquitetura civil) e hidráulica, abrangendo arquitetura civil, materiais de construção, estradas, pontes, portos e canais.

Essa escola teve início anterior ao da primeira escola de Engenharia dos Estados Unidos - a Academia Militar West Point, de 1802.

Em 4 de dezembro de 1810, foi criada a Academia Real Militar, que veio substituir a Real Academia de Artilharia, Fortificação e Desenho. Embora fosse um estabelecimento militar, além do ensino profissional de artilharia e engenharia militar (fortificação, ataque e defesa das praças), manteve-se a citada cadeira de engenharia civil e acrescentaram-se as de ensino de ciências matemáticas, de ciência de observação, quais a Física, Química, Mineralogia, Metalurgia e História Natural.

Além destas disciplinas, ainda ministrava-se, num curso ampliado para sete anos, cálculo infinitesimal, geometria descritiva, astronomia, geodesia, geografia. Esta ampliação foi muito importante para o ensino das ciências e para a posterior pós-graduação. 
Em 1832, as academias, Militar e de Guardas-Marinha fundiram-se na Academia Militar e de Marinha, quando foram criados os títulos de engenheiro geógrafo (quatro anos de curso matemático e prática do observatório) e de engenheiro de pontes e calçadas (três anos de curso matemático e dois anos da cadeira de engenharia civil criada em 1792).

Apesar destas duas academias separarem-se em 1833, o curso de pontes e calçadas subsistiu até 1839 na Academia Militar, que passou a chamar-se Escola Militar, oferecendo cursos de infantaria, cavalaria, artilharia e engenharia.

Se em 1810 a Academia Real Militar não admitia alunos civis, foi somente em 1842 que alunos civis e militares ficaram em pé de igualdade, prenunciando o curso de engenharia civil que seria criado em 1858.

Diante deste histórico nota-se que o Ensino de Engenharia iniciou-se em bases militares e somente em 1858 é que alunos não-militares puderam freqüentar as mesmas aulas.

Em 25 de abril de 1874, foi criada a Escola Politécnica do Rio de Janeiro.

Segundo BAZZO \& PEREIRA (1997), até 1946 já existiam quinze instituições de ensino de engenharia no Brasil. Estas instituições, a partir de nova demanda gradualmente foram se expandindo, crescendo e recebendo cada vez mais alunos aumentando conseqüentemente o número de escolas, de professores e de pessoas ligadas ao ensino até se chegar nos dias atuais.

SACADURA (1999), aponta que essa busca cronológica feita da profissão dos engenheiros, permitiu identificar, além de grande diversidade de características e situações observadas, alguns elementos comuns. A engenharia é uma área 
profissional criativa: envolve competências científicas, tecnológicas, econômicas, de animação e gestão de organizações. A ela se encontra estreitamente associado um papel de chefia de atividades humanas; com alto grau de responsabilidade econômica e social. Esses fatores ressaltam a ligação entre ciência-tecnologia-sociedade.

\subsection{Situação atual}

Atualmente, existe um número bastante elevado de escolas de engenharia renomadas e conhecidas, sendo no país mais de trezentas. Desde o seu surgimento, as escolas procuram atender um mercado em crescimento e em constante evolução.

Antigamente o engenheiro recém formado ingressava no mercado de trabalho sem maiores problemas tanto no que se refere à disponibilidade de postos de trabalho, quanto às habilidades exigidas. A tecnologia emergente exigia engenheiros para a sua absorção e implantação. A questão da qualidade do ensino estava longe de ser colocada. Não havia necessidade de se pensar nessa questão.

Esta situação, porém, foi se modificando por várias razões: escassez de emprego no mercado de trabalho, excesso de conhecimento acumulado pela humanidade, modelos educacionais que não conseguem fazer com que os novos conhecimentos sejam absorvidos integralmente por seus alunos, e tecnologias para a sua difusão, entre outros. Esses fatores combinados levaram a uma situação incomum: um maior distanciamento entre o conhecimento disponível e os métodos e técnicas disponíveis e aplicados para lidar com ele (vide Figura 2). 


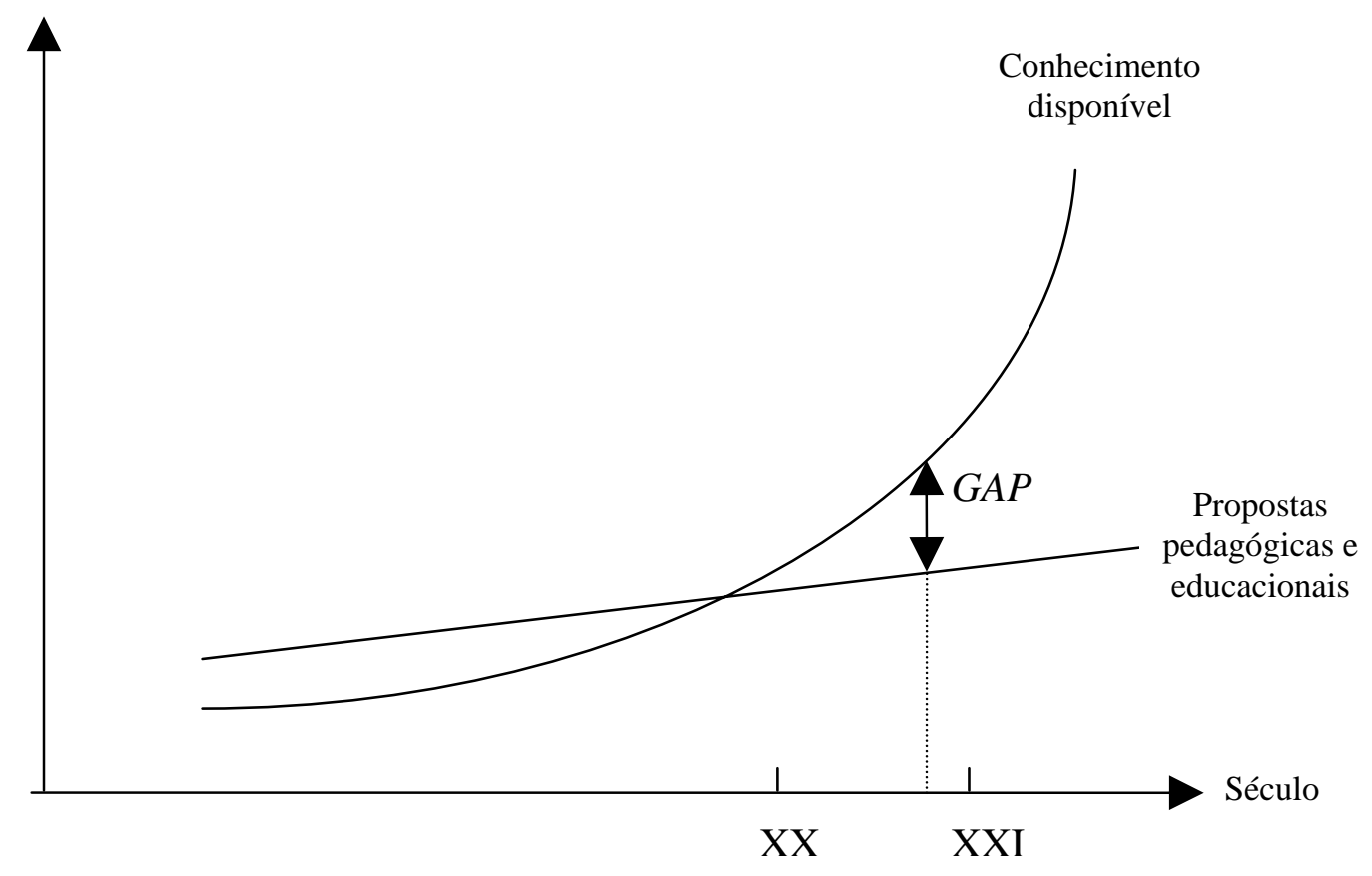

FIGURA 2. Gap Educacional (BELHOT, 1997: 67)

Uma primeira avaliação exploratória mostra que em muitos casos, a universidade não acompanha as mudanças do mercado de trabalho, principalmente no mercado brasileiro, onde se verifica um alto nível de dependência tecnológica. Nos países sede, onde se situam as matrizes das empresas transacionais a integração universidade-empresa é um fator preponderante para o processo de inovação, dando origem ao novo conhecimento que passa a estabelecer a hegemonia econômica principalmente. A empresa estabelecida no mercado brasileiro por força do modelo de industrialização não recorre, via de regra, à universidade brasileira, mas à matriz internacional e esta, a universidade em seu país de origem. Algumas vezes, tem sido possível constatar que a empresa no Brasil, recorre diretamente, a universidade situada nos países de origem. COLENCI JR (1992) faz importante constatação neste sentido. 
Além de não acompanhar as mudanças tecnológicas, a universidade também não dá suporte para a sociedade através das habilidades como o know how, know why, skill e feeling. Os professores, de uma maneira geral, seguem o esquema giz e lousa e os alunos fazem anotações e estudam para as provas. É o modelo tradicional da educação existente para formar mão de obra e não um profissional multifuncional capaz de pensar e agir com flexibilidade e iniciativa. $\mathrm{O}$ aluno ao receber o conhecimento pronto, não se preocupa em procurar novas soluções para os problemas existentes, ou mesmo identificar novos problemas e quando ingressa no mercado de trabalho vai lidar justamente com novas situações. Já os professores, até por falta de matérias pedagógicas em sua formação, não utilizam metodologias de ensino que desenvolvam no aluno novas formas de agir e pensar, apesar de farto material disponível. Geralmente dão aula da forma como aprenderam em sua época de estudante.

Por seu lado, as grandes organizações desenvolvem programas de treinamento que se estendem por até dois anos, mantendo os novos profissionais na desconfortável situação de "trainées” como tentativa de fazer com que esses alunos criem habilidades que deveriam ser desenvolvidas pelas universidades, o que é uma prova do distanciamento reinante, segundo COLENCI (1998), do ponto de vista da aquisição de técnicas e não da formação.

$\mathrm{Na}$ tentativa de se conseguir elementos para melhor analisar o processo educativo, serão descritas, a seguir, as principais abordagens do processo de ensinoaprendizagem. 


\subsection{Principais abordagens}

Várias abordagens são empregadas no ensino de engenharia, e o professor utiliza-se de uma ou mais destas abordagens, consciente ou inconscientemente. A mistura dos modelos se faz com aspectos das abordagens tradicional, comportamental e humanista, no entanto, além destas, existe na pedagogia brasileira também a abordagem sócio-cultural e abordagem cognitivista. Estas cinco abordagens foram assim sistematizadas por MIZUKAMI (1996).

\section{Abordagem Tradicional}

A abordagem tradicional, é a concepção mais antiga da educação e passou a ser a base de referência para outras abordagens.

Nesta abordagem o conhecimento é centrado no professor. Volta-se ao que é externo ao aluno, como os programas e as disciplinas. O aluno só executa o que é prescrito por autoridades, independente de sua vontade.

O homem é visto como uma “tabula rasa” como um receptor passivo inserido no mundo, que irá conhecê-lo através de informações formais que lhe são transmitidas. A inteligência tem papel importante pois é através dela que o aluno irá armazenar e memorizar as informações transmitidas.

Ainda segundo MIZUKAMI (1996), a educação é entendida como processo de instrução e as decisões são verticalizadas pois tudo é feito em função do mestre e de seu comando. A aprendizagem é considerada como tendo um fim em si mesma e os conteúdos e informações podem ser adquiridos e os modelos imitados. Ignora as 
diferenças individuais e trabalhos em grupo, enfatiza o verbalismo do mestre e a memorização dos alunos.

As tarefas são padronizadas e não existe interação entre os alunos. A metodologia usada constitui-se de aulas expositivas e demonstração pelo professor, segundo KURI (1990).

O professor já traz o conteúdo pronto e o aluno limita-se a escutá-lo passivamente. O trabalho intelectual do aluno se inicia após a aula. A avaliação é realizada visando a exatidão da reprodução de conteúdos, tem um fim em si mesma e as notas obtidas funcionam no mundo social como nível cultural e intelectual.

O ensino tradicional prioriza a disciplina intelectual e conhecimentos abstratos. Os programas são minuciosos e rígidos, os exames são seletivos e o diploma é a consagração final do ciclo de estudos. O conhecimento é estático, passando de geração a geração, e a escola é o local de apropriação do conhecimento por meio da transmissão de conteúdos.

A avaliação é um processo uniforme pois espera-se que todos os alunos ofereçam o mesmo padrão de respostas uniformes.

\section{Abordagem Comportamental}

Segundo MIZUKAMI (1986), esta abordagem caracteriza-se por estar centrada no conhecimento. Tanto para os comportamentalistas behavioristas como para os instrumentalistas e positivistas lógicos, a experiência é a base do conhecimento. O uso da tecnologia educacional libera o professor de uma série de tarefas, principalmente a de ensinar através de aulas expositivas, que são substituídas 
por materiais auto-instrutivos e recursos audiovisuais que garantem aos alunos, considerados recipientes de informação, a auto-aprendizagem dos conteúdos.

De acordo com SCHULTZ (1992), a psicologia tal como vê o comportamentalista, é um ramo puramente objetivo e experimental da ciência natural, seu objetivo teórico O comportamento humano é modelado ou reforçado, através de treinamento segundo objetivos pré-fixados. As ações precisam acontecer para que sejam reforçadas, segundo KELLER (1983).

O homem é visto como conseqüência das forças e influências do meio ambiente, o mundo já é constituído e o homem é apenas um produto do meio. A experiência planejada é considerada a base do conhecimento. A educação está intimamente ligada à transmissão cultural.

O ensino-aprendizagem consiste num arranjo e planejamento de contingência de reforço sob os quais os estudantes aprendem e é responsabilidade do professor assegurar a aquisição do comportamento. Os comportamentos desejáveis do aluno são controlados e mantidos por condicionantes e reforçadores arbitrários, como elogios, notas, prêmios, reconhecimento dos mestres e colegas, prestígio pessoal, etc; e reforçadores mais remotos, como o diploma, as vantagens da futura profissão, possibilidades de ascensão social, etc. A garantia da aprendizagem é a programação.

Na relação professor-aluno, cabe aos educandos o controle do processo de aprendizagem, um controle científico da educação. O professor é considerado um planejador e um analista de contingências. É um “engenheiro comportamental”. A avaliação parte do pressuposto de que o aluno progride em seu ritmo próprio, em pequenos passos, sem cometer erros, a avaliação consiste em se constatar se o aluno 
atingiu os objetivos propostos. Na maioria das vezes a avaliação inicia o próprio processo, através de uma pré-testagem dos pré-requisitos, a partir dos quais serão planejadas e executadas as etapas seguintes.

Nesta abordagem o homem é um produto do meio reativo a ele. O ensino é tratado em função de uma tecnologia que, além da aplicação de conhecimentos científicos, a prática pedagógica envolve a tecnologia educacional, ficando claro que tudo deve ser meticulosamente programado.

\section{Abordagem Humanista}

Esta abordagem é centrada no sujeito. O conhecimento advém das experiências do próprio aluno e o professor é considerado o facilitador do processo. Esta abordagem no Brasil apresenta dois enfoques predominantes: a de A. Neill, classificada como espontaneísta, propõe que o aluno desenvolva-se sem intervenções; e a de Carl Rogers, cuja proposta é identificada como representativa da psicologia humanista que enfatiza as relações interpessoais e ao crescimento que delas resulta.

Uma importante contribuição de Carl Rogers é a abordagem conhecida como terapia na pessoa ou terapia centrada no cliente. Rogers propôs que cada pessoa possui uma tendência inata para atualizar as capacidades e potenciais do eu. Ele atribui a responsabilidade da mudança de personalidade à pessoa ou cliente e não ao terapeuta. São as próprias pessoas que alteram consciente e racionalmente seus pensamentos e comportamentos, conforme SCHULTZ (1992). 
MIZUKAMI (1986), interpretando esta abordagem, salienta que o homem é considerado como um indivíduo em processo contínuo de descoberta de seu próprio ser, ligando-se a outras pessoas do grupo. A experiência pessoal e subjetiva é o fundamento sobre o qual o conhecimento é constituído. É atribuído ao sujeito o papel central na elaboração e criação do conhecimento. Ao experienciar, vivenciar, o homem conhece.

A responsabilidade da educação é do próprio estudante. A educação tem como finalidade primeira à criação de condições que facilitem a aprendizagem. Suas características são: a auto-descoberta e a auto-determinação. O ensino-aprendizagem ocorre como decorrência das proposições rogerianas sobre o homem e o mundo, o ensino está centralizado na pessoa, o que implica em técnicas de dirigir sem dirigir.

A finalidade do método não diretivo é que a pessoa possa estruturar-se e agir levada pela sua própria experiência. O professor não ensina, cria condições para que o aluno aprenda. O aluno constrói o conteúdo. A competência do professor está na forma de relacionamento com o aluno. O aluno aprende fazendo (pesquisa, descoberta, solução de problemas, trabalho em grupo).

Com relação à avaliação, parte do pressuposto de que as pessoas aprendem o que desejam aprender. Considera-se nesta abordagem, que prêmios, notas e exames desviam o desenvolvimento da personalidade. Tudo o que o aluno precisa aprender são as ferramentas básicas para se aprender o restante (aprender a aprender). A autoavaliação é bastante enfatizada, pois só o indivíduo pode conhecer realmente sua experiência e assumir responsabilidades por formas de controle de sua aprendizagem. (MIZUKAMI, 1986). 
Os conteúdos vindos de fora passam a assumir importância secundária e privilegia-se a interação estabelecida entre as pessoas envolvidas numa situação de ensino-aprendizagem. O diretivismo no ensino caracterizado pelas abordagens anteriores, é aqui substituído pelo não-diretivismo, às relações verticais pelas horizontais e as avaliações com padrões prefixados pela auto-avaliação.

\section{Abordagem Sócio-Cultural}

Seu principal precursor é Paulo Freire. Essa abordagem enfatiza os aspectos sócio-político-culturais mais significativos no contexto brasileiro. Trata-se de uma abordagem interacionista, embora seja o sujeito o elaborador e criador do conhecimento.

Na abordagem de Freire, segundo MIZUKAMI (1983), o homem é o sujeito da educação e apesar desta grande ênfase no sujeito, evidencia-se uma tendência interacionista, já que a interação homem-mundo, sujeito-objeto é imprescindível para que o ser humano se desenvolva e se torne sujeito. O homem é que cria sua cultura na medida em que reflete criticamente sobre o seu contexto, e dá respostas aos desafios.

Cultura para Freire é: “... todo resultado da atividade humana, do esforço criador e recriador do homem, de seu trabalho por transformar e estabelecer relações dialogais com outros homens.” (FREIRE, 1974). Neste caso, cultura constitui-se na aquisição crítica e criadora da experiência humana e não o simples armazenamento de informações também conhecido como “ensino bancário” (FREIRE, 1975). A conscientização para Freire também é uma palavra forte. Implica na desmistificação 
da realidade do oprimido em relação ao opressor. Daí a necessidade do trabalho humanizante ser um trabalho de desmistificação, consistindo a conscientização numa tomada de consciência mais crítica. Somente com a libertação é que se vai tornar possível a humanização que supõe a eliminação da opressão desumanizadora.

\section{Abordagem Cognitivista}

Segundo MIZUKAMI (1986), cognitivistas são psicólogos que investigam processos centrais do indivíduo, dificilmente observáveis, como organização do conhecimento, estilos de pensamento, estilos cognitivos, comportamentos relativos à tomada de decisões. Implica estudar cientificamente a aprendizagem como sendo mais um produto do ambiente interno das pessoas que de fatores externos aos alunos. Dão ênfase aos processos cognitivos e à investigação científica separados dos problemas sociais contemporâneos. As emoções são consideradas em suas articulações com o conhecimento.

Este tipo de abordagem é predominantemente interacionista e seu principal representante é o suíço Jean Piaget, que segundo SCHULTZ (1992), produziu importantes obras acerca do desenvolvimento cognitivo e teve grande importância na época.

Segundo MIZUKAMI (1986), o conhecimento nesta abordagem é a interação entre o sujeito e o objeto. O indivíduo é considerado um sistema aberto, em reestruturações sucessivas, em busca de um estágio final nunca alcançado. Os estágios formam-se um após o outro e a estruturação mental vai se acumulando. 
O conhecimento é considerado como uma construção contínua. A passagem de um estado de conhecimento para outro é sempre caracterizada por formação de novas estruturas que não existiam anteriormente no indivíduo. A educação resume-se em provocar situações de desequilíbrio para o aluno, adequado ao seu desenvolvimento, de forma que seja possível a construção progressiva das noções e operações, ao mesmo tempo em que vive tanto intelectual como afetivamente, cada etapa de seu desenvolvimento.

O objetivo da educação é fazer com que o aluno aprenda por si mesmo, a conquistar a verdade. A educação é condição necessária ao desenvolvimento natural do ser humano e sua primeira tarefa deveria ser a de desenvolver o raciocínio, devendo, ainda, provocar no aluno a busca de soluções e estimular novas estratégias de compreensão da realidade. O desenvolvimento da observação é muito importante e a liberdade de ação dos indivíduos é de fundamental importância para seu desenvolvimento motor, mental e verbal. Aprender significa assimilar o objeto a esquemas mentais.

Ainda segundo MIZUKAMI (1986), o ensino de acordo com esta teoria, é baseado no ensaio e erro, na pesquisa e na investigação, na solução de problemas por parte do aluno e não na aprendizagem de fórmulas, nomenclaturas, definições etc. O ponto fundamental do ensino é o processo e não o produto. A aprendizagem verdadeira só se realiza quando o aluno elabora seu conhecimento. É necessário considerar o "aprender a aprender”. Cabe ao professor criar situações, propiciando condições em que se possam estabelecer reciprocidade intelectual e cooperação, ao mesmo tempo moral e racional, fazer desafios, evitar rotinas, fixação de respostas e hábitos. Cabe ao aluno um papel ativo em suas atividades básicas, as quais deverão 
consistir em observar, experimentar, comparar, relacionar, analisar, justapor, compor, encaixar, levantar hipóteses e argumentar. Como metodologia educacional, o trabalho em grupo assume papel fundamental.

Na avaliação, uma das formas de avaliar o rendimento escolar é através de reproduções livres, com expressões próprias, relacionamentos, explicações práticas. Não há pressão no sentido de desenvolvimento acadêmico e desempenhos padronizados.

Para Piaget, segundo MIZUKAMI (1986), a aprendizagem como fixação de respostas padronizadas conforme ocorre na abordagem comportamental é a mais arcaica que existe e não considera o não-diretivismo da proposta rogeriana apenas como respeito dado ao aluno quanto a sua própria atividade.

Busca-se como uma especificidade desta abordagem, adaptada à formação profissional, um tratamento centrado na aprendizagem, com radical mudança no papel do “professor”.

É interessante frisar o comportamento docente uma vez que podem estar ocorrendo situações pré-tayloristas, dado o grau de improvisação ou descompromisso com os objetivos dos cursos, existindo um descompasso nos esforços despendidos. Se não há planejamento e preparação, tem lugar a improvisação, o que não é aceitável no caso. O docente, quanto ao seu comportamento e ao nível das abordagens metodológicas propostas, desempenha um papel fundamental numa educação funcional para o ambiente e para o desenvolvimento.

Essas abordagens estão intimamente atreladas à prática docente mas é preciso entender em que nível se encontra o ensino de engenharia. Para essa discussão, foi 
feita uma analogia entre o processo de produção e o processo educacional, descritos a seguir.

\subsection{Onsino de Engenharia à Imagem da Manufatura: Estratégias de Desenvolvimento e Critérios Utilizados}

Para entender o atual estágio da educação em engenharia e perscrutar a necessidade de mudança de paradigmas pode-se lançar mão do modelo evolutivo desenvolvido por BELHOT (1997), apresentado na Figura 3.

Sabe-se que o setor secundário da economia está passando por profundas mudanças nos processos de gestão da produção, que podem ser caracterizadas como mudanças de paradigmas, evoluindo-se da produção em massa para a produção enxuta. Comparativamente, pode-se notar que o processo educacional, no caso, o ensino de engenharia, também se apresenta em fase de transição, com inúmeras características de similaridade.

Num primeiro momento da história, como se estuda na Engenharia de Produção, havia a produção artesanal, em que, o conhecimento da manufatura e a própria produção se fundiam em uma só pessoa, no próprio artesão que com suas ferramentas e método próprio produzia determinado produto (BELHOT, 1997). As habilidades exigidas eram as habilidades do trabalho, aprendidas no ambiente da tarefa manual. Na educação também se pode observar essa fase artesanal, que foi a fase em que o mestre, na época chamado de tutor ou mentor, ensinava uma só criança 
por vez e dedicava-se a ela durante toda a sua vida até que esta alcançasse um nível elevado de aprendizado.
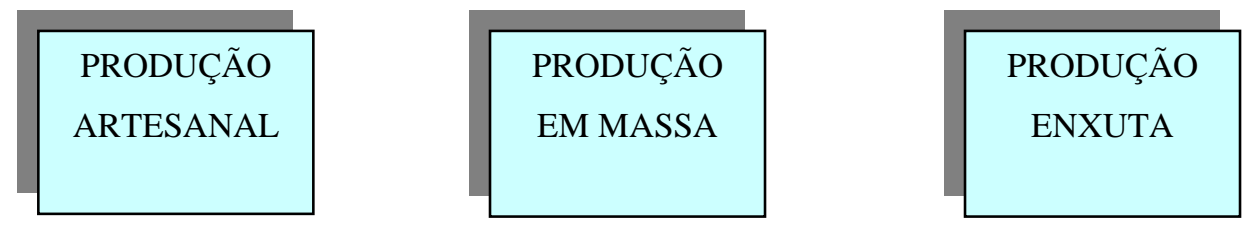

\section{PROCESSO DE PRODUCÃ̃}

(tempo)

PROCESSO EDUCACIONAL
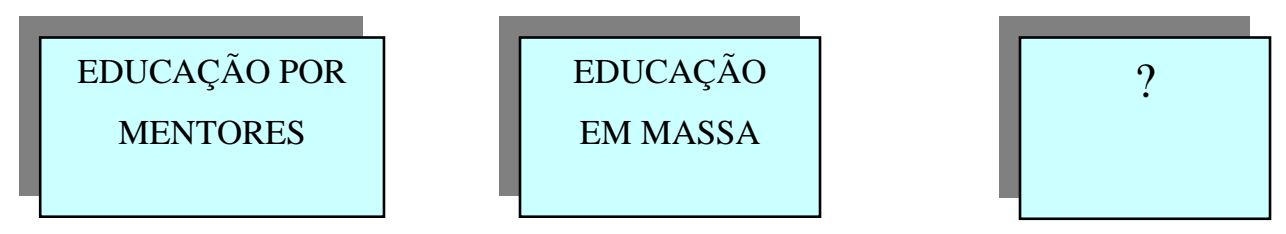

FIGURA 3. Comparação evolutiva entre processos de produção e processos educacionais (adaptada de Belhot, 1997)

Evolutivamente ocorreu, na indústria, conforme salienta CHIAVENATO (1993), a produção em massa, que sob a Teoria Científica, teve otimizado os esforços da produção, com base em conceitos e princípios que prevalecem até hoje. A divisão 
técnica ou horizontal do trabalho, a separação entre planejamento e execução, a comunicação unívoca, o controle rígido, a padronização, o aumento da escala de produção balizam até hoje grande parte da atividade industrial (ESCRIVÃO, 1998). Para otimizar resultados separa-se o conhecimento e a decisão, da tarefa de execução, gravando-se a mão de obra com forte alienação e elitizando-se a gerência. As indústrias que atuam sob esta onda denominada por TOFLER (1978), a Segunda Onda, priorizam a intensificação do uso dos recursos e estabelecem indicadores de desempenho para a produtividade. Na educação, ocorre algo semelhante, procurando estabelecer-se medidores de desempenho únicos, a partir de uma atuação centrada no mentor do ensino: professor, desconsiderando-se as características heterogêneas dos alunos e do meio. Este professor pode ser considerado como sendo a própria gerência, que tende a tratar todos os seus alunos da mesma forma. Por meio de atitudes estruturadas, o ambiente de ensino se apresenta gerenciado por ordens e regras. Dá-se o sinal de entrada e a "grande massa” adentra a sala de aula e tende a atuar segundo processos previamente estabelecidos até ser transformada e sair como produto final que é colocado à disposição do mercado. Se não servir, é peça rejeitada e se sobrar, é estoque.

Nos dias de hoje, as indústrias buscam uma atuação dirigida ao atendimento das necessidades dos clientes, oferecendo produtos diferenciados e individualizados (customização), gerados em processos flexíveis, de modo a garantir o pleno atendimento com qualidade, baixo custo e no tempo certo - inovatividade e flexibilidade, o que pode ser entendido como Produção Enxuta.

Seguindo esta mesma orientação, é preciso analisar a educação através de um novo enfoque que busque a melhoria da aprendizagem do aluno, de modo a capacitá- 
lo efetivamente para as demandas individualizadas estabelecidas pelo mercado e de modo a formar um profissional divergente, analítico, construtivista, que adquira na sua formação o know how, o know why, o skill e o feeling, gerando respostas criativas no processo, num ritmo variável com comportamento flexível e igualitário, sendo capaz de trabalhar em equipe e ter iniciativa e liderança.

\subsection{Mudança de foco: $O$ Ensinar e o Aprender}

Os estudos dedicados às questões educacionais na área de engenharia já demonstram que não é mais suficiente olhar a educação apenas sob a ótica do ensino em massa, onde o critério dominante é tão somente a utilização eficiente dos recursos (professores, sala de aula e outros recursos materiais e de informações). Urge priorizar a aprendizagem, voltar a atenção para os clientes, para suas necessidades e buscar novos paradigmas que satisfaçam essas demandas a partir das potencialidades em curso. Para que isso aconteça, deve-se deslocar o foco do "ensinar” para o “aprender”, isto é, a atividade básica deve estar voltada para o estudante.

A Tabela (1) aponta diferença do enfoque centrado no ensino e o enfoque centrado na aprendizagem. (COLENCI JR 1998). 
TABELA 1 - Diferentes enfoques do processo educacional.

\begin{tabular}{|c|c|c|}
\hline COMPONENTE & $\begin{array}{c}\text { ENFOQUE CENTRADO } \\
\text { NO ENSINO }\end{array}$ & $\begin{array}{c}\text { ENFOQUE CENTRADO NA } \\
\text { APRENDIZAGEM }\end{array}$ \\
\hline Foco & Docente & Estudante \\
\hline Docente & Provedor de Conhecimentos & Facilitador da Aprendizagem \\
\hline Estímulo & Informação Abstrata, não pertinente & $\begin{array}{l}\text { Situação de Aprendizagem Real, } \\
\text { Pertinente }\end{array}$ \\
\hline Processo Mental & Convergente, Memorizador & $\begin{array}{ll}\text { Divergente, } & \text { Analítico, } \\
\text { Construtivista } & \\
\end{array}$ \\
\hline Objetivos & $\begin{array}{l}\text { Informacional, Discursivo; } \\
\text { Resposta Correta. Aprender por si. }\end{array}$ & 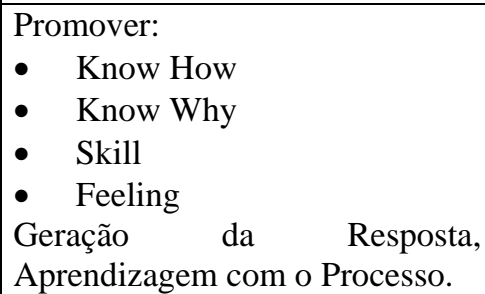 \\
\hline Ritmo & Uniforme & Variável \\
\hline Comportamento & Rígido: Autoritário & Flexível; Igualitário \\
\hline Efeitos & $\begin{array}{|lrr|}\text { Promove o } & \text { Individualismo; } & \text { Cria } \\
\text { Dependência } & & \\
\end{array}$ & $\begin{array}{l}\text { Fomenta o Trabalho em Equipe; } \\
\text { Favorece a Iniciativa; Prestigia a } \\
\text { Liderança }\end{array}$ \\
\hline
\end{tabular}

Esta teoria, do enfoque centrado na aprendizagem, já descrita por Carl Rogers em 1924, toma o aluno como centro do processo educativo mediante um estilo de aula tão diferente quanto atrativo e estimulante, que suprime a aula expositiva e estimula a aprendizagem e o desenvolvimento de novas habilidades do aluno. Seria o chamado paradigma da educação personalizada onde o aluno passa a não ser mais tratado como matéria prima e sim como um cliente personalíssimo (PUENTE, 1978).

Para se entender esse novo requisito, uma das maneiras é compreender a educação como uma atividade de serviços, e não mais como uma transformadora de insumos em produtos conforme aponta a Figura 4. O aluno assim como a matéria prima passa por uma transformação e torna-se um produto (recém-formado) que irá atender as exigências do mercado e da sociedade. 


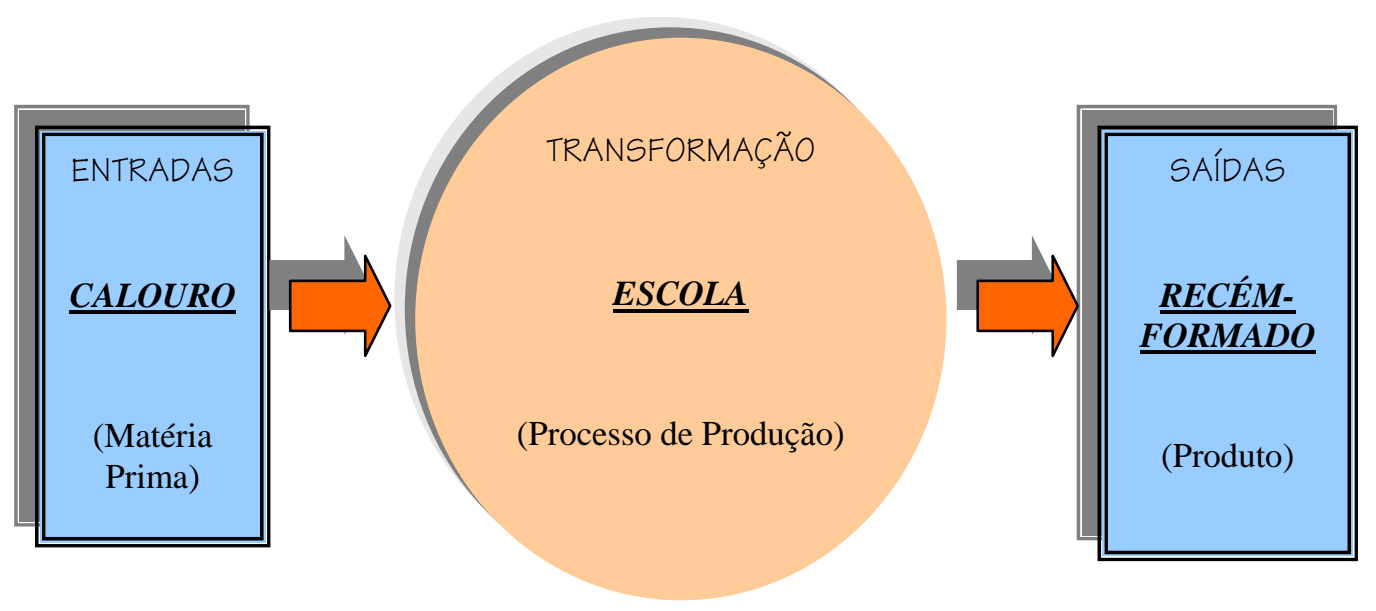

FIGURA 4. A visão tradicional do processo educacional à semelhança do processo de produção.

Da mesma forma, a Tabela 2 faz idêntica analogia do processo de produção com a educação tal qual se encontra atualmente. REBELATTO (1999), afirma que nesta analogia simplista os graduados competem por um trabalho assim como os produtos competem por um lugar nas prateleiras do mercado. O aluno formado é o produto final cujo cliente é o empregador. Os alunos formados correspondem às vendas realizadas, os desempregados corresponderiam num primeiro momento aos estoques, e permanecendo nesta condição, aos saldos.

REBELATTO (1999), ainda afirma que se tem uma sugestão de medida de desempenho das instituições que desenvolvem os cursos de formação profissional. O que parece ocorrer é a universidade ser avaliada pelo número de estudantes que recebe o diploma, e não por quantos conseguem efetivamente emprego no mercado de trabalho para garantir sobrevivência. 
TABELA 2. Aspectos da analogia entre ensino superior e processo de produção em massa. (adaptado de REBELATTO 1999).

\begin{tabular}{ll}
\hline Ensino Superior Usualmente Realizado & Processo Produção Em Massa \\
\hline Escola de Segundo grau & Fornecedor \\
Calouro & Matéria-prima \\
Aluno & Produto em processamento \\
Curso & Processo produtivo \\
Formado & Produto final \\
Empregador & Cliente \\
Formandos empregados & Vendas \\
Formandos desempregados & Estoque ou saldo \\
Salário inicial & Preço do produto
\end{tabular}

É neste ponto que surge a necessidade de se pensar a qualidade do processo ensino-aprendizagem por que ao serem prestados, estes serviços estarão atendendo as necessidades de alguém, o cliente.

Somente agora está havendo uma reunião do conhecimento necessário para se prover mudanças na educação, pois o ensino é uma das únicas ocupações importantes do homem para a qual ainda não foram aperfeiçoados instrumentos que tornem uma pessoa média capaz de ser competente e ter um bom desempenho. 
Pode-se afirmar que no ensino de engenharia o bom professor já nasce feito, pois se confia nas aptidões inatas, daqueles que de alguma forma sabem ensinar. Assim, a busca por melhores resultados passa necessariamente pelo acesso a instrumentos adequados e pela organização apropriada do trabalho, dos potenciais “bons docentes”. Neste ponto ressalta-se a importância da interface entre a educação ou pedagogia e as outras áreas do conhecimento, principalmente engenharia onde cresce a preocupação com a melhoria da qualidade do ensino.

Além disso, segundo BARREIRO (1996) muitos dos professores contratados pelas universidades exercem a docência por obrigação contratual. Não gostam de ser chamados de bons professores porque isso, conforme o senso comum, tornou-se sinônimo de que eles não são bons pesquisadores. Neste caso, interpõe-se um distanciamento entre pesquisa e docência.

Cabe aqui reconhecer conforme salienta DRUCKER (1968) que a pesquisa gera informações e não conhecimento, e que a capacidade de organização para a aplicação das informações aos resultados finais é o processo de desenvolvimento do “conhecimento”. Mais que isso, busca-se o profissional capaz de reunir conhecimentos e habilidades de muitas disciplinas integrando-os na aplicação efetiva para solucionar problemas futuros. Isso não poderá ser feito sem a presença de um pesquisador que seja efetivamente um bom professor.

Como pode ser observado, há realmente uma mudança de perfil profissional ocasionada por mudanças sociais e econômicas. Com isso, começa-se a pensar no novo papel de todo profissional, entre eles o profissional-professor, na importância da metodologia científica, na didática e também na postura da própria universidade que deve atender as necessidades de um mercado em constante evolução ocasionada 
por novas tecnologias. Acima de tudo, a universidade deve atender as necessidades da sociedade tornando o estudante um profissional e um cidadão. 


\section{CAPÍTULO 2}

NOVAS EXIGÊNCIAS DE ATUAÇÃO ACADÊMICA NO CENÁRIO GLOBALIZADO

\subsection{A mudança nas organizações e as organizações de aprendizagem}

À medida que o panorama político, econômico e social vai se modificando, modificam-se também as organizações e conseqüentemente os papéis desempenhados por seus agentes. Concomitantemente, os agentes podem provocar mudanças na sociedade.

Atualmente, sob uma nova mudança de paradigma iniciada em meados de 1990, uma nova forma de analisar a organização e a gerência vem surgindo. Nas organizações de aprendizagem estudadas por Peter Senge, o conhecimento e a aprendizagem são os fatores essenciais para o sucesso e cabe ao líder desta organização fazer com que todos passem da condição de meros trabalhadores para trabalhadores aprendizes.

SENGE (1990), traz uma relevante contribuição neste sentido. Enfatiza a importância da aprendizagem dentro das organizações como sendo a única forma a partir da qual as pessoas ampliam continuamente a sua capacidade de criar em direção aos resultados que realmente desejam, onde surgem novos e elevados padrões de raciocínio, a aspiração coletiva é libertada e as pessoas expandem o 
aprender em grupo. Para o autor, as organizações só aprendem através de indivíduos que aprendem. O aprendizado individual não garante o aprendizado organizacional, mas sem ele não há como ocorrer esse tipo de aprendizagem na organização. Ele propõe a implementação de cinco disciplinas que são programas permanentes de estudo e prática que elevam o aprendizado organizacional e continuam sempre as mesmas, porque o que importa é adquirir as capacidades fundamentais para a organização, e são elas: Domínio Pessoal, Modelos Mentais, Objetivo Comum, Aprendizado em Grupo e Pensamento Sistêmico, que serão melhor abordadas.

\section{Domínio Pessoal}

Domínio Pessoal, significa aprender a expandir as capacidades pessoais para obter resultados desejados e criar um ambiente empresarial que estimule todos os participantes a alcançar as metas escolhidas. O empenho e a capacidade de aprendizado de uma organização não pode ser maior que a dos membros que a compõem. O Domínio Pessoal vai além da habilidade e competência, embora seja baseado em habilidade e competência. Está baseado em crescimento espiritual e trabalho criativo, ao contrário de reativo. Está intimamente ligado com o estabelecimento de objetivos pessoais - condição necessária para que a organização possa determinar objetivos globais.

\section{Modelos Mentais}

São idéias arraigadas, generalizações e imagens que influenciam o modo de encarar o mundo e atitudes pessoais e que influenciam toda a organização. 
A mudança consiste em refletir, esclarecer continuamente e melhorar a imagem que cada um tem do mundo, a fim de verificar como moldar atos e decisões. Isso pode ser feito através de aprendizado institucional que levará toda a equipe a modificar seus modelos mentais.

\section{Objetivo Comum}

É o mesmo que visão compartilhada. É estimular o engajamento do grupo em relação ao futuro que se procura criar e elaborar os princípios e diretrizes que permitirão que este futuro seja alcançado. Segundo SENGE (1990), quando existe um objetivo concreto e legítimo, as pessoas dão tudo de si e aprendem, não por obrigação, mas por livre e espontânea vontade. Esse objetivo comum se sobrepõe aos objetivos individuais dos membros do grupo. Já Taylor estabelece que os objetivos da empresa devem estar acima dos objetivos individuais. A mudança se dá em como estabelecer essa aproximação de forma harmônica.

\section{Aprendizado em Grupo}

Está em transformar as aptidões coletivas ligadas a pensamento e comunicação, de maneira que grupos de pessoas possam desenvolver inteligência e capacidades maiores do que a soma dos talentos individuais, característica esta também chamada de sinergia.

SENGE (1990), afirma que o aprendizado em grupo começa com o “diálogo”, a capacidade de os membros de um grupo levantarem idéias preconcebidas e participarem de um “raciocínio em grupo” onde todas as pessoas se respeitem mutuamente. 


\section{Pensamento Sistêmico}

O pensamento sistêmico é a quinta disciplina pois é a disciplina que integra as outras quatro, fundindo-as num conjunto coerente de teoria e prática, evitando que cada uma delas sejam vistas isoladamente como simples macetes ou o último modismo para efetuar mudanças na organização. O raciocínio sistêmico está sempre mostrando que o todo pode ser maior que a simples soma das partes.

O pensamento sistêmico é entendido como uma forma de criar, de analisar uma linguagem para descrever e compreender as forças e inter-relações que modelam o comportamento dos sistemas. É a quinta disciplina que permite mudar os sistemas com maior eficácia e agir mais de acordo com os processos do mundo natural e econômico.

Nesta nova visão, todos os membros da organização caminham para o mesmo objetivo. O administrador torna-se planejador e pesquisador. Desempenha a função de projetista, guia e professor. Não há mais comando e sim controle nascido do acompanhamento. Em todos os níveis existem líderes, líderes de equipes, gerentes de desenvolvimento, gerentes de vendas, gerentes de unidades de produção. O poder é subdividido, não há mais uma hierarquia a ser seguida. Muda-se o status quo da organização apresentada até então. Neste sentido, surge o aparecimento de um novo tipo de dirigente, que esteja disposto a associar seu aprendizado pessoal à ação coletiva da organização. Vai mais além das abordagens anteriores pois ressalta a necessidade do conhecimento e a aprendizagem em equipe, o que antes não era considerado desta forma. 


\subsection{O momento atual}

Uma boa maneira de descrever o momento atual é: mudanças. DRUCKER (1968) salienta que a única verdade imutável em nossos dias é a mudança. Mundialmente estas mudanças estão ocorrendo no sentido da globalização e consequentemente na mudança de paradigmas e do próprio perfil profissional, falando especificamente do engenheiro.

Segundo REBELATTO (1999), a globalização é vista como uma expansão sem precedentes do papel do mercado na coordenação da economia mundial, provocando prejuízos para a capacidade regulatória do Estado, além de criar o pânico do desemprego crescente e permanente.

Crises como estas já foram superadas em tempos atrás, como por exemplo, na Revolução Industrial, onde as máquinas deixaram desempregadas, milhares de pessoas. O grande desafio está em adaptar-se a essas mudanças correntes.

Hoje, fala-se em adaptação a este cenário através de um novo perfil profissional. RUIZ (1998), afirma que segundo vários especialistas, o que importa hoje é ser um profissional capaz de ocupar diferentes cargos e funções durante a carreira independentemente do curso escolhido na universidade e mais, o importante é estar sempre aprendendo. Mas isso só se consegue se o profissional tiver desenvolvido a capacidade de aprender, pesquisar, avaliar, solucionar problemas e decidir. São essas habilidades desenvolvidas na universidade que vão fazer com que o profissional exerça com êxito seu papel. 
Neste ponto começa-se a interligar a educação com o processo de globalização e de constantes mudanças. É através da educação que os profissionais poderão acompanhar estas transformações. A informação está disponível em todos os lugares, seja através de jornais e revistas ou da internet. O grande problema está em assimilar o conhecimento, tornando-o um corpo consistente e aplicável. Nas organizações já se fala há algum tempo em uma organização que tenha como princípio fundamental a aprendizagem.

Como se sabe, a universidade não tem acompanhado as mudanças tecnológicas. A maioria ainda segue o esquema dos moldes tradicionais do ensino, de giz e lousa, onde o professor escreve na lousa e o aluno copia e estuda para a prova encarando a avaliação como um fim em si mesma ou de reprodução de conhecimento, que acaba por formar “técnicos” e não “gente que pensa”, RUIZ (1998).

KURI (1990), aponta em seus estudos que as práticas didático-pedagógicas mais utilizadas pelos professores que ministram aulas com altos níveis de reprovação, evidenciam acentuada preferência pelos métodos de ensino com utilização quase exclusiva de aulas expositivas e atividades que se iniciam após a exposição, através da resolução de exercícios e problemas propostos pelo professor, métodos estes que poderiam ser chamados de tradicionais.

Estes métodos tradicionais, no entanto, enfatizam apenas um tipo de aprendizagem, deixando de lado algumas outras possibilidades de desenvolvimento do aluno.

GARDNER (1995), que desenvolveu a teoria das múltiplas inteligências, afirma que cada pessoa tem componentes de sete inteligências, que são: inteligência musical, inteligência corporal-cineástica, inteligência lógico-matemática, inteligência 
lingüística, inteligência visual-espacial, inteligência interpessoal e inteligência intrapessoal. Para cada uma são apresentadas características que descrevem a maneira de aprender ou de reagir ao ambiente.

1) Inteligência Musical - Caracteriza-se pela facilidade de reconhecimento da estrutura musical, esquemas para ouvir música, criação de melodias e ritmos. Está ligada, segundo GARDNER (1995), pela sensibilidade aos sons do ambiente, dos ritmos e batidas, e manipulação de instrumentos musicais.

2) Inteligência Corporal-Cineástica - É a habilidade relacionada à parte corpórea da pessoa. É a capacidade de usar o próprio corpo para expressar uma emoção como na dança, no esporte, ou na criação de produtos. O perfil indica funções corporais desenvolvidas, alerta através do corpo, controle dos movimentos voluntários, habilidades miméticas.

3) Inteligência Lógico-Matemática - Está associada ao raciocínio científico, indutivo e às vezes dedutivo. Envolve a capacidade de trabalhar com símbolos e com modelos. Juntamente com a associada capacidade da linguagem, o raciocínio lógicomatemático proporciona a principal base para os testes de QI.

4) Inteligência Lingüística - está relacionada às linguagens escrita e falada e diretamente às palavras. É responsável pela produção da linguagem, incluindo metáforas, contar histórias, leitura, escrita, poesia. O perfil aponta para explicar, ensinar e aprender, senso de humor, memória e lembrança, e entendimento da ordem e significado das palavras. segundo GARDNER (1995). 
5) Inteligência Visual / Espacial - Apóia-se na capacidade de visualização espacial de um objeto e na criação de imagens mentais. O perfil aponta para a percepção acurada de diferentes ângulos, representação gráfica, imaginação ativa, como o jogo de xadrez, por exemplo.

6) Inteligência Interpessoal - Está baseada na capacidade de perceber distinções entre os outros, em especial, contrastes em seus estados de ânimo, temperamentos, motivações e intenções. É cooperativo, demonstra capacidade para trabalhar em grupo. Tem bom relacionamento social e facilidade para entender as pessoas.

7) Inteligência Intrapessoal - Segundo GARDNER (1995), está ligada a metacognição (refletir sobre o refletir), à auto-reflexão, e à sensibilidade frente aos aspectos espirituais. As características indicam concentração, percepção e expressão dos diferentes sentimentos íntimos. A pessoa com boa inteligência intrapessoal possui um modelo viável de si mesma.

Não se pode medir inteligência através de um único instrumento avaliatório. A palavra inteligência, de uma maneira geral nas escolas é utilizada como uma “faculdade singular” utilizada em qualquer situação na solução de problemas. GARDNER (1993) afirma que a inteligência dentro dessa nova abordagem consiste em um conjunto de capacidades, talentos ou habilidades mentais, encontrada em graus variáveis em todos os indivíduos. Ela é a chave para o sucesso na resolução de problemas. O autor baseia-se nesta afirmativa uma vez que em casos práticos, pode 
verificar que nem sempre o profissional que vai bem em testes de inteligência desenvolvidos nas escolas, é sempre o melhor no campo de trabalho.

BELHOT (1997), afirma que segundo a teoria de Gardner, sobre múltiplas inteligências, o ensino tradicional enfatiza a inteligência lingüística e a matemática basicamente, deixando em desvantagem os alunos que apresentam outros tipos de inteligência. Essa teoria traz grande impacto uma vez que representa canal aberto para a aprendizagem.

\subsection{As novas habilidades}

Hoje existem novas propostas de trabalho que auxiliam o aluno no desenvolvimento de novas habilidades, que são: o aprender a aprender, flexibilidade, trabalho em equipes, entre outros. Essas novas habilidades, transformam não só o profissional mas o próprio aluno como cidadão, como ser social que vai atuar numa sociedade em constante mudança e vai desempenhar seu próprio papel para que ela se torne mais justa e igualitária, não sendo mais apenas um reprodutor fiel de parâmetros vigentes da sociedade atual.

\subsection{1. $\mathrm{O}$ aprender $\mathrm{a}$ aprender}

Nos últimos anos, o tema de mudança tem sido constante e acende debates acadêmicos e profissionais em torno de que as universidades brasileiras e as próprias 
organizações precisam mudar e que as pessoas precisam aprender a mudar, aprender a aprender.

O aprender a aprender consiste na postura do aluno em ter habilidade de buscar o conhecimento, de acessá-lo e incorporá-lo e de abrir novos horizontes por si só.

DEMO (1995), afirma que hoje a expectativa lançada sobre o desafio do aprender a aprender vai além do mero ensinar e do mero aprender. Na didática usual, “ensino/aprendizagem” diz respeito à absorção do conhecimento, permanecendo o educando como objeto receptivo e domesticado. Quando se fala em aprender a aprender, enfoca-se menos os produtos a serem dominados e mais a pessoa, que se torna capaz de saber pensar, de avaliar processos, de criticar e criar.

No “ensinar”, cabe menos o desafio de emancipação, que é entendido como a libertação do sujeito que se torna ator consciente e produtivo, do que a imposição domesticadora que leva a reproduzir “atores de massa”, segundo DEMO (1995).

Para que haja efetivamente o aprender a aprender, o estímulo à pesquisa torna-se fator essencial para que isso aconteça.

\subsubsection{A importância da pesquisa}

A atitude de pesquisa é o cerne do aprender a aprender. “A pesquisa como atitude, significa princípio científico e educativo, ou seja, a base da produção científica, a base da educação ancorada no manejo e produção do conhecimento. Faz parte de todo processo educativo emancipatório, porque fundamenta a postura crítica 
e criativa diante da realidade e leva a intervir com base no conhecimento renovado e renovador.” (DEMO, 1995: 213). Neste caso, a pesquisa é meio para despertar e motivar a atitude de investigação, questionamento, criatividade, curiosidade crítica entre outros fatores que irão fazer com que o próprio aluno chegue ao conhecimento, aprenda a buscar o conhecimento, aprenda a aprender. Com isso ele será capaz de buscar os novos conhecimentos produzidos, não se tornará obsoleto frente às mudanças decorrentes de novas tecnologias. Será um profissional "recriado", diferente dos vigentes, capaz de construir um projeto próprio educativo e assistencial, ao mesmo tempo competente cientificamente e participativo politicamente.

Pode-se dizer que não há ensino sem pesquisa e pesquisa sem ensino. "Enquanto ensino, continuo buscando, reprocurando. Ensino porque busco, porque indaguei e me indago. Pesquiso para constatar, constatando, intervenho, intervindo, educo e me educo. Pesquiso para conhecer o que ainda não conheço e comunicar ou anunciar a novidade” (FREIRE, 1996, p.32).

\subsubsection{Flexibilidade}

A flexibilidade e a adaptabilidade serão atributos cada vez mais essenciais da Nova Escola. Com as freqüentes mudanças de tecnologias e novos equipamentos, os profissionais devem estar aptos a se adaptar a qualquer ambiente e a trabalhar com novos desafios. Seria uma conseqüência do aprender a aprender, pois o profissional torna-se flexível quando aprende a aprender. Adapta-se a novos ambientes e se depara com novos desafios, tendo habilidade para resolver os problemas apresentados em qualquer situação. 


\subsubsection{Trabalho em grupo}

Cada vez mais se exige no mercado de trabalho o agrupamento de profissionais em equipes. É comprovado que quando as pessoas trabalham em grupo, elas realizam mais, tanto em termos quantitativos como em termos qualitativos.

Segundo COLENCI et al. (1999), o mercado de trabalho tem adotado a formação de equipes de trabalho como alternativa estrutural. Mudando a forma de trabalho, muda-se também o perfil do profissional que neste caso, está passando de uma postura individualista para uma postura coletiva. A universidade, como responsável pela formação do profissional, está intimamente ligada a esta mudança de perfil.

NÉRICI (1967), aponta que a educação por muito tempo, foi um transmitir experiência, voltada mais para o passado do que para o presente e o futuro. $\mathrm{Na}$ verdade, as exigências eram poucas com relação à educação devido à vida rudimentar e a pouca densidade educacional. Com o passar do tempo, o homem foi tomando consciência de si mesmo enquanto a vida social foi se tornando mais exigente e com isso a educação se tornava insuficiente. Era preciso olhar para o presente e descobrir novas formas de ação que atendessem a novas necessidades. $\mathrm{O}$ trabalho em grupo hoje, é visto como uma forma metodológica alternativa que vai mudar a própria prática educacional.

O trabalho em grupo ou em equipe, que por questões práticas não serão diferenciados em sua terminologia, não é apenas um agrupamento de pessoas mas sim um agrupamento de pessoas com sinergia e comprometimento. Através dessa 
técnica, as pessoas entram em contato com visões de mundos diferentes, aprendem a se socializar, a ouvir e dar opiniões sobre determinado assunto a aceitar outras sugestões, a formar uma mentalidade de grupo, a concentrar a atenção, a ter iniciativa, entre outros. Uma vantagem considerável do trabalho em grupo é que a soma das partes será maior que cada parte separadamente.

ALMEIDA (1973), enfatiza a importância grupal devido a fatores sociais, psicológicos e pedagógicos.

Com relação aos fatores sociais, entende que o trabalho em grupo possibilita uma vivência maior em sociedade, dando oportunidade do surgimento de novos líderes, de novas funções além de preparar este indivíduo para a própria sociedade dando-lhe oportunidade de convivência e preparando-o para a vida futura e principalmente profissional.

Devido a fatores psicológicos: as pessoas tendem a se esconder em um mundo individual e impenetrável. O autor entende que através do trabalho em grupo pode-se eliminar inibições e limitações.

Através dos fatores pedagógicos: o trabalho em grupo, em geral, torna a atividade mais agradável possibilita a realização de uma atividade comum, com objetivos comuns, possibilitando enriquecimento de experiências e vivências.

GUILLON (1994:120), aponta que nos processos educacionais, a equipe é “um pequeno número de pessoas com conhecimentos complementares, compromissadas com propósito, metas de desempenho e abordagem comuns e pelos quais se mantêm mutuamente responsáveis”. Este autor afirma que quando as 
pessoas trabalham em equipe, elas realizam mais, tanto em termos qualitativos como em termos quantitativos.

Para que seja possível o trabalho em grupo é necessário que haja um clima que estimule as pessoas a trabalhar em conjunto, e cabe aos membros da universidade enfatizar o valor do trabalho em equipe.

As atividades grupais não devem ser iniciadas abruptamente. É preciso que o professor prepare e planeje as atividades. Segundo ALMEIDA (1973), podem ser aplicadas por fases, entre as quais, sondagem da clientela e do ambiente de trabalho, onde se faz necessário o professor conhecer em primeiro lugar seus clientes e o ambiente de trabalho; preparação dos elementos, pois se o professor e os alunos não estiverem aptos a trabalhar em grupo haverá indisciplina e desânimo acarretando resultados negativos; em seguida vem o processo de formação das equipes que poderá ser de forma natural onde os alunos escolhem seu grupo ou de forma induzida quando o professor escolhe os parceiros com algum fim mais objetivo; a execução das atividades que é a própria aplicação técnica da atividade; e o processo de avaliação que poderá ser individual ou em equipe.

MINICUCCI (1982) afirma que o grupo passará por uma evolução e maturidade onde cada indivíduo irá satisfazer duas classes de necessidades, a de aprender e a de atuar conforme mostra a Figura 5. 


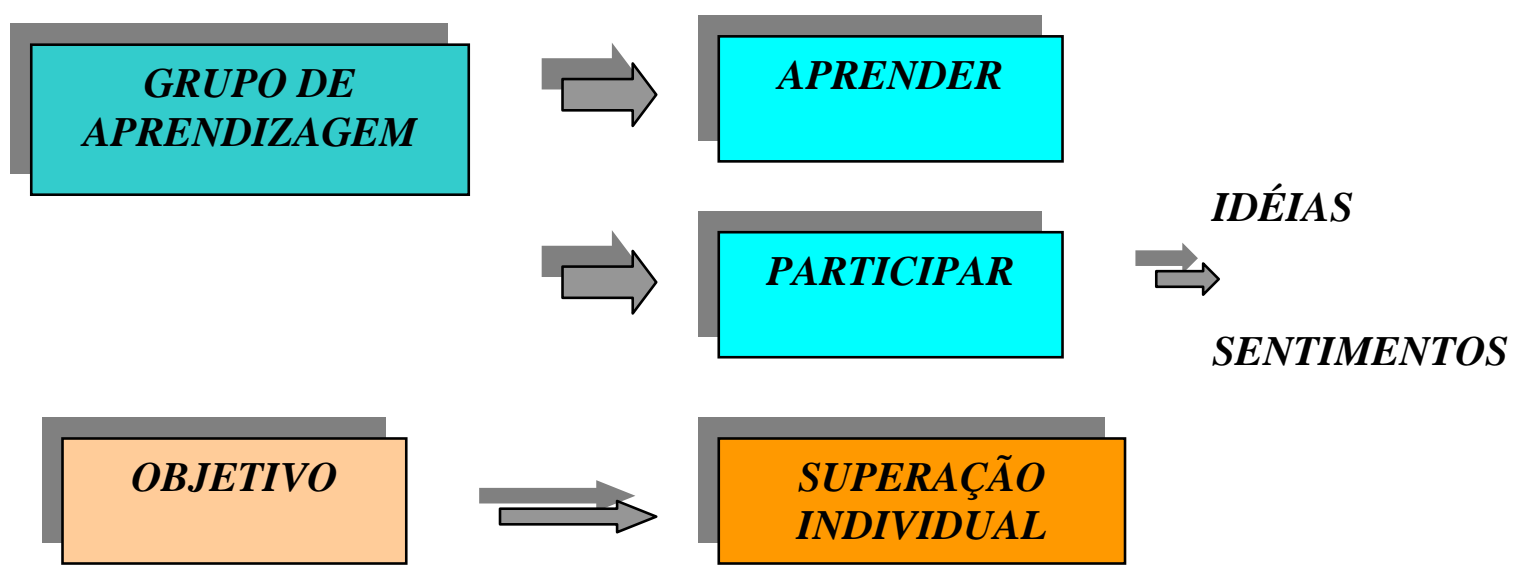

FIGURA 5. Grupo de aprendizagem. (Adaptada de MINICUCCI, 1982).

A necessidade de aprender com os demais, de partilhar com os outros nossas idéias, sentimentos, de conseguir um melhor entrosamento com as pessoas e com o mundo é o que motiva a formação dos grupos de aprendizagem.

O trabalho em grupo, se iniciado na universidade, possibilita uma melhor formação do indivíduo pois novas habilidades estarão sendo desenvolvidas. Desta forma, quando o profissional ingressa no mercado de trabalho encontra-se apto a desenvolver atividades requeridas pela organização. Com relação à sociedade, por ser o indivíduo um ser social, ao trabalhar em grupo, estará se aperfeiçoando nas relações sociais.

Neste específico ponto é que se constata a necessidade de mudança de paradigma para o processo educacional. Os moldes tradicionais não estão mais sendo eficazes para formar profissionais de engenharia. Este paradigma da educação em massa deve ser substituído por outro, o qual enfoca a educação como uma atividade de prestação de serviços, a qual será abordada no capítulo 5. 


\subsection{Novas propostas de trabalho}

Estas novas competências elencadas no item anterior (aprender a aprender, o trabalho em grupo e a flexibilidade), podem ser desenvolvidas através de atividades como, jogos simulados, aprendizado baseado em problemas e por descoberta, atividades de pesquisa, entre outros. Estas atividades desenvolvem no aluno a capacidade de aplicar informações trabalhadas em novas situações reais.

\subsubsection{Simulação e Jogos}

ABT (1974), nos ensina que à medida que a civilização evolui para sociedades altamente tecnológicas, a capacidade de usar abstrações torna-se cada vez mais necessária para as pessoas atuarem eficientemente. Neste caso, os jogos oferecem um campo rico para uma exploração ativa, sem riscos de sérios problemas intelectuais e sociais. Através dos jogos os homens podem, mais uma vez, desempenhar os papéis emocionantes e dinâmicos com os quais sempre se deleitou antes da sociedade se tornar tão dividida em compartimentos. O desempenho que os estudantes assumem nos jogos que simulam a vida é excelente preparação para os papéis reais que mais tarde desempenharão na sociedade.

Difícil é encontrar nos dias atuais pessoas para quem o jogo, em suas diferentes modalidades, não seja algo contagiante e envolvente. É por isso que está sendo utilizado como técnica de ensino e treinamento, mas eles não podem ser aplicados apenas para criar um ambiente descontraído em sala de aula, devem fazer 
parte do planejamento de ensino visando uma situação de aprendizagem e o alcance de certos objetivos pré-determinados.

A simulação, é utilizada por muitas razões, mas o propósito principal é ajudar a entender e resolver problemas complexos e reais, construindo uma versão simplificada do problema ou sistema, na opinião de BELHOT (1997).

Os jogos simulados, por sua vez, de acordo com RONCA (1984) fazem parte de um processo intrinsecamente competitivo, pois existem ganhadores e perdedores e através desta estratégia os jogadores assumem papéis que são representativos do mundo real e tomam decisões em função dos papéis assumidos.

Assim sendo, esta estratégia além de motivar o aluno, apresenta dois componentes principais, um racional, analítico, e um emocional, criador e dramático que são essenciais para o desenvolvimento das competências nos alunos, conforme ABT (1974).

A seqüência de passos para o projeto e aplicação de jogos e simulação é muito semelhante à seqüência usada na aprendizagem baseada em problemas, que é, a fixação de objetivos; determinação do contexto; identificação dos recursos; determinação da seqüência de interações; ambientação e aplicação em si.

\subsubsection{Aprendizagem baseada em problemas}

Um outro método interessante é a Aprendizagem Baseada em Problemas.

Segundo BELHOT (1997), a Aprendizagem Baseada em Problemas- ABP (Problem-Based Learning - PBL), é um método instrucional caracterizado pelo uso 
de problemas reais, como o contexto para que os estudantes aprendam a ter uma postura crítica e as habilidades necessárias para resolver problemas, além de adquirir conhecimento dos conceitos essenciais. Usando PBL, os estudantes adquirem habilidades duradouras, que incluem a capacidade de descobrir e usar recursos de aprendizagem apropriados.

Na Aprendizagem Baseada em Problemas (ABP) o problema é utilizado como estímulo à aquisição de conhecimento e compreensão de conceitos. Com a evolução do currículo, o estudante também usa cada problema para desenvolver habilidades na solução de problemas. Trata-se de um método convergente, que atrai diversas áreas do conhecimento em busca de soluções.

A Aprendizagem Baseada em Problemas pode ocorrer tanto de maneira individual como em pequenos grupos, porém, é no grupo de tutoria que o pensamento crítico pode ser encorajado e os argumentos levantados, idéias podem ser construídas de maneira criativa, novos caminhos podem ser estabelecidos, permitindo a análise coletiva de problemas que espelhem a prática profissional futura.

\subsubsection{Aprendizagem por descoberta}

Um dos importantes métodos educacionais consiste na aprendizagem direcionada a descoberta.

Segundo RONCA (1984), a descoberta é uma condição necessária para a aprendizagem das diversas técnicas para a solução de problemas. A prática na descoberta ensina a adquirir informação de uma forma tal que a mesma se torne mais 
viável na solução de problemas. A aprendizagem por descoberta refere-se à situação de ensino na qual o professor não explica conceitos e princípios para os alunos mas lhes fornece exemplos e problemas a partir dos quais os estudantes poderão induzir estes conceitos e princípios. Os alunos, muitas vezes cometem erros ou falsas induções nos quais o professor deve interferir mas é normal que isso aconteça e também de fundamental importância pois é desta forma que em futuras soluções, os alunos saberão qual melhor caminho a seguir.

A aprendizagem por descoberta além de ser uma maneira do aluno aprender a matéria, apresenta também um fim em si mesma, o aprender a descobrir. Desta forma, o recém formado que se vê diante de uma nova situação, utiliza-se da competência de aprender a descobrir, para solucionar o problema apresentado.

\subsubsection{Aprendizagem Cooperativa e Aprendizagem Ativa}

A aprendizagem ativa e a aprendizagem cooperativa estão incluídas nos métodos da pedagogia renovada. Surgiram em contrapartida aos métodos tradicionais. Segundo UNI (1998), o aprendizado ativo não requer do aluno apenas ficar "alerta” e "escutar", requer que ele desenvolva atividades e reflita sobre o que está fazendo. Estas atividades consistem em trabalhos intelectuais, emocionais e psicomotores, como atividades de leitura, escrita, discussão e solução de problemas. São atividades que utilizam grande raciocínio.

Se o professor quiser desenvolver a aprendizagem ativa, deve assumir que o ato de ensinar vai além da transmissão de informação. O papel do professor é 
encorajar e ajudar os estudantes no processo de aprendizagem de uma maneira significativa que na maioria dos casos se faz com a cobertura do conteúdo e com o processo de aprendizagem.

Os estudantes não apenas aprendem mas também ensinam uns aos outros. Segundo UNI (1998), esta atividade foi reconhecida como uma estratégia de ensino apenas recentemente. A atividade cooperativa, promove o aprendizado ativo em pequenos grupos onde os membros destes pequenos grupos, além de aprenderem também ensinam seus companheiros.

O aprendizado cooperativo é, segundo SMYSER (1995) “uma técnica onde os estudantes ajudam uns aos outros no processo de aprendizagem atuando como parceiros do professor e deles próprios, com objetivo de aprender determinado conteúdo”.

As principais características do aprendizado cooperativo, são:

- Avaliação individual, de acordo com o progresso do grupo;

- Interdependência positiva: nenhum aluno acha que obteve sucesso a não ser que todo o grupo também obtenha;

- Melhor entendimento da matéria, pois os alunos devem explicá-la aos colegas;

- Desenvolvimento de relações interpessoais, o que será útil na vida profissional, em trabalhos de equipe;

- Desenvolvimento da habilidade de analisar a dinâmica e o trabalho do grupo sobre os problemas;

- É uma maneira comprovada de aumentar o envolvimento do aluno na sala de aula, conforme SMYSER (1995), que adicionalmente afirma que pesquisas mostram que este tipo de aprendizado cooperativo conduz à maior atividade intelectual, o que facilita tarefas como análise, síntese, avaliação e solução de problemas. 


\section{CAPÍTULO 4}

\section{A ÓTICA DE SERVIÇOS}

Atualmente, o setor de serviços vem recebendo maior atenção em função de sua importância para a economia atual. Não só produtos garantem o sucesso, os serviços agora exercem papel crítico na competitividade das empresas. Na verdade o pacote de soluções ao cliente compreende harmonizar o produto, serviços e informações.

A educação, vista analogamente sob a ótica da manufatura apresenta algumas características conforme descrito no capítulo 2 que já não é em si tão suficiente para englobar todas as necessidades e características da educação. Para se entender a educação sob um novo enfoque, analisá-la sob uma nova lente, é preciso conceituar e entender o que seja serviços para depois se fazer um paralelo entre educação e serviços.

\subsection{O que é um serviço?}

ELLENRIEDER (1988) afirma que a conceituação de um serviço pode ser intuitiva, mas não é simples. 
Historicamente, os serviços nasceram como atividade econômica na era préindustrial, associados ao serviço pessoal prestado por um indivíduo a outro, diferente da relação de servidão, comum na época. Podiam estar relacionados com o atendimento das necessidades do patrão pelos seus criados-empregados ou com aqueles de maior prestígio social como o atendimento de necessidades impostas pelo corpo, prestados por médicos, taberneiros ou cortesãs; ou necessidades do espírito, prestadas por sacerdotes, artistas ou quiromantes. Existiam também os prestamistas que eram aqueles que financiavam as companhias militares e outras aventuras. No caso do primeiro grupo de servidores, a dos criados-empregados, a relação com o cliente era em geral humilhante.

Com o surgimento das primeiras indústrias, houve um impacto substancial sobre o serviço pessoal. As fábricas introduziram o conceito de trabalho assalariado, que modificou o conceito de servidão. A remuneração do operário da fábrica começa, aos poucos, ser maior que a da maioria dos servidores individuais. Neste caso, o relacionamento estabelecido nas fábricas entre patrão e operário e uma melhor remuneração por parte destes, eliminou o vínculo de posse entre amo e servo, mudou o conceito de serviços e deu origem ao surgimento de pequenas firmas de empresários independentes ou de servidores autônomos.

Um outro fator, mais recente, que fortaleceu a atividade de serviços foi à extensão do conceito de "produto". À medida que os produtos se tornaram mais sofisticados, os clientes passaram a precisar de um suporte para utilizar melhor estes produtos. Uma câmara fotográfica (produto), por exemplo, requer revelação dos filmes e treinamento sobre como fotografar com perfeição (serviço). Neste caso, 
muitos serviços surgiram como apêndices e complementos de manufatura de produtos.

Atualmente a atividade de serviços vem crescendo de forma acelerada. Segundo GIANESI \& CORRÊA (1995), a importância das atividades de serviços pode ser demonstrada por dois lados. Primeiro, pela posição que ocupam na economia, seja através da participação do Produto Interno Bruto (PIB) ou na geração de empregos, e segundo, pela análise das tendências e transformações que a economia mundial está experimentando. Alguns fatores que propiciam o aumento da demanda por serviços são:

- Desejo de melhor qualidade de vida;

- Mais tempo de lazer;

- A urbanização, tornando necessários alguns serviços;

- Mudanças demográficas que aumentam a quantidade de crianças e idosos, os quais consomem maior variedade de serviços;

- Mudanças socioeconômicas como o aumento da participação da mulher no trabalho remunerado e pressões sobre o tempo pessoal;

- Aumento da sofisticação dos consumidores, levando a necessidades mais amplas de serviços;

- Mudanças tecnológicas (como o avanço dos computadores e das telecomunicações) que têm aumentado a qualidade dos serviços, ou ainda tem criado serviços completamente novos. 
Paralelamente, as atividades de serviços exercem papel importante no desempenho de outros setores da economia. Este papel pode ser definido em três categorias:

- Como diferencial competitivo - as organizações diferenciam seus serviços para melhor agradar seus clientes, gerando com isso um aumento de competitividade;

- Como suporte às atividades oferecidas - Para se desenvolver bem uma atividade, a organização necessita de vários serviços. Dentro dessas organizações há o cliente interno que precisa de um bom suporte para desenvolver seu trabalho;

- Como geradores de lucro - além de terem a função de apoio, os serviços podem tornar-se “centro de lucro da organização”.

É muito difícil dar uma definição para serviços, pois sempre há uma menção incompleta ou alguma falha em seu conceito. Porém, de uma forma mais definitiva, conceitua-se serviço, como “...uma operação ou conjunto de operações, cujo objetivo é aumentar o valor do estado de alguma pessoa ou objeto" diferentemente do conceito de manufatura que é “...uma operação ou conjunto de operações que tem por objetivo aumentar o valor de forma de insumos físicos” (ELLENRIEDER, 1998:4) ou: “serviço é gerado pelas atividades de interação entre o fornecedor e o cliente, onde as atividades dos clientes podem ser essenciais ao fornecimento do serviço e a entrega do uso de algum produto pode fazer a oferta conforme a ISO 9004-2”. 


\subsection{Características dos serviços}

Há quatro características muito importantes associadas aos serviços: intangibilidade, inseparabilidade, heterogeneidade, perecibilidade que serão descritas a seguir:

- Intangibilidade: a primeira e também a mais marcante característica dos serviços é a intangibilidade. Esta característica demonstra que os serviços são abstratos. Enquanto os produtos são coisas que podem ser possuídas, os serviços são experiências que o cliente vivencia, segundo GIANESI \& CORRÊA (1994). Basicamente significa uma experiência que não pode ser tocada, ouvida, cheirada ou provada pelo consumidor, mas é percebida pelo cliente.

A intangibilidade dos serviços torna difícil para o gerente, os funcionários e o cliente avaliar o resultado e a qualidade do serviço, por isso percebem mas riscos nas compras de serviços do que de produtos.

Embora haja exceções, os serviços são de difícil padronização o que torna a gestão do processo mais complexa.

Os serviços são fáceis de serem desenvolvidos e modificados, por isso há sempre a proliferação de serviços similares, mesmo porque falta uma legislação de registros e patentes para este setor, o que torna permitida a cópia de um serviço para outros concorrentes, dificultando a manutenção de vantagens competitivas e atitudes inovadoras. 
Por serem os serviços abstratos, ao compará-los com outras atividades de marketing requer-se um tratamento especial. Não se faz promoção e propaganda de um serviço igual à de um produto.

- Inseparabilidade ou simultaneidade: Esta característica demonstra que não há uma etapa intermediária entre a produção de um serviço e seu consumo, pois estes são simultâneos, são produzidos e consumidos ao mesmo tempo, sendo assim diferente da manufatura onde os bens são produzidos, estocados, vendidos e mais tarde consumidos.

A presença do cliente ou de um bem de sua propriedade é fundamental para desencadear o processo de serviço. Esta interação permite maior visibilidade, para os clientes, do modo de operação da empresa. Em razão disso, a qualidade final não será apenas resultado da satisfação advinda com o serviço, mas também do processo de fornecimento do serviço (atendimento), no qual o cliente julgará seus aspectos físicos, o comportamento e aparência das pessoas envolvidas COWELL (1988).

- Heterogeneidade: outra característica dos serviços é a heterogeneidade ou variabilidade, que significa que os serviços são altamente variáveis. Dependem das pessoas que os executam, do tempo, do tipo de serviço, ambiente, local, cliente, entre outros.

Certas organizações ao buscarem uma padronização, procuram aumentar a eficiência, a confiabilidade e a qualidade dos serviços, segundo LEVITT (1976) e sua idéia de "industrialização" de certos tipos de serviços. Mas a característica de heterogeneidade pode trazer um certo grau de competitividade para as organizações que se destacarem. 
- Perecibilidade: esta característica demonstra que os serviços não podem ser estocados já que a produção e o consumo são simultâneos. Neste caso, é mais difícil haver um equilíbrio entre demanda e oferta devido à flutuação da procura pelo serviço que ora pode ser alta, ora pode ser baixa. O equilíbrio entre a capacidade produtiva e demanda representa uma questão-chave para o gerenciamento estratégico dos serviços. Neste ponto, LABEGALINI (1997) conclui que se torna importante dar liberdade ao pessoal da linha de frente para raciocinar e decidir. Ganha-se desta forma, o comprometimento das pessoas que são co-responsáveis pelo sucesso da empresa.

Segundo LAS CASAS (1994), há diferentes tipos de serviços a serem comercializados. Um consultor de empresas, por exemplo, tem como enfoque seu conhecimento, é como um advogado, um professor ou um outro profissional liberal. O objeto de comercialização é intangível. Além deste tipo de serviço, há outros que são consumidos junto com bens; neste caso, o objeto de comercialização inclui produtos tangíveis e intangíveis, por exemplo, os restaurantes onde há refeições (tangível) e a prestação de serviços de atendimento ao cliente (intangível). Não adianta apenas servir uma boa refeição ou apenas dar um bom atendimento, estes bens estão interligados. LAS CASAS (1994), aponta na Figura 6 o contínuo entre produtos e serviços. 


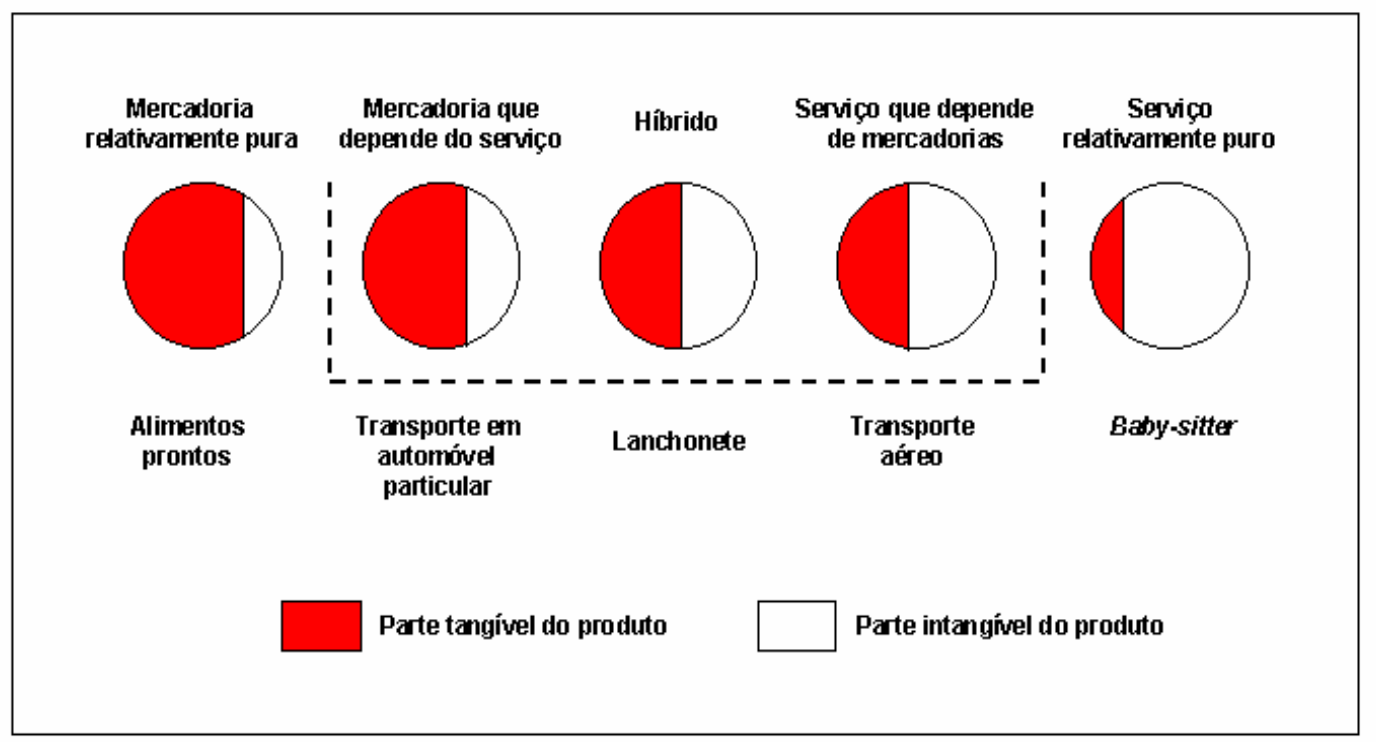

FIGURA 6. Contínuo entre produtos e serviços (adaptado de Las Casas: 1994).

Enquanto um produto se associa a um serviço para resultar um benefício ao usuário, ao serviço oferecido, também se associa um serviço prestado, ou o modo como se oferece o serviço para resultar em benefício percebido pelo usuário (COLENCI, 1999).

Esta divisão dos diferentes tipos de serviços serve, principalmente para sugerir diferenças no tratamento mercadológico de cada uma das categorias.

\subsection{Qualidade em Serviços}

No Brasil, a maneira pela qual os clientes são tratados é de certa forma negligente em relação à qualidade de prestação de serviços. É só fazer o teste: quem nunca foi mal atendido por um comerciante ou um prestador de serviços? Neste caso 
a idéia é a de que o consumidor tem que se adaptar à prestação de serviços brasileiros, o que é um absurdo, segundo LAS CASAS (1994).

Atualmente este quadro está mudando, porque a preocupação com a qualidade em serviços tem aumentado. Mas, o que é qualidade em serviços?

Segundo ALBRECHT (1992), qualidade em serviços é a capacidade que uma experiência ou qualquer outro fator tenha para satisfazer uma necessidade, resolver um problema ou fornecer benefícios para alguém.

Neste caso, é a diferença entre os resultados e as expectativas que vai fazer com que o cliente tenha um certo grau de satisfação ou insatisfação em relação ao serviço prestado.

Os serviços possuem dois componentes de qualidade que devem ser considerados: o serviço em si e a forma como é percebido pelo cliente.

Atualmente fala-se muito em qualidade total. Este termo segundo ALBRECHT (1992:24), é “uma situação na qual uma organização fornece qualidade e serviços superiores a seus clientes, proprietários e funcionários”.

O gerenciamento da qualidade total também conhecido como “TQM (Total Quality Management)”, enfoca cinco preceitos básicos:

- Foco no cliente;

- Desenvolvimento de um estilo de gerenciamento por intermédio de fatos;

- Incentivo à melhoria contínua;

- Busca de envolvimento total com a organização interna;

- Apoio sistêmico à força de trabalho 
Foi na manufatura que ocorreu a maior parte das iniciativas de implementação dos conceitos de qualidade total com experiências, através de “círculos de qualidade” e "equipes”. Atualmente é no setor de serviços que a TQM vem sendo implantada.

\subsubsection{Avaliação da qualidade em serviço}

Como se sabe, uma das características dos serviços é a de que sua avaliação não pode ser feita antes da compra e sim durante o processo de prestação do serviço ou, em alguns casos, somente após ser conhecido o seu resultado. A avaliação que o cliente faz, durante ou após o término do processo, se dá através da comparação entre o que o cliente esperava do serviço e o que ele percebeu do serviço prestado. A Figura 7 mostra a avaliação do cliente frente as suas expectativas e sua percepção.

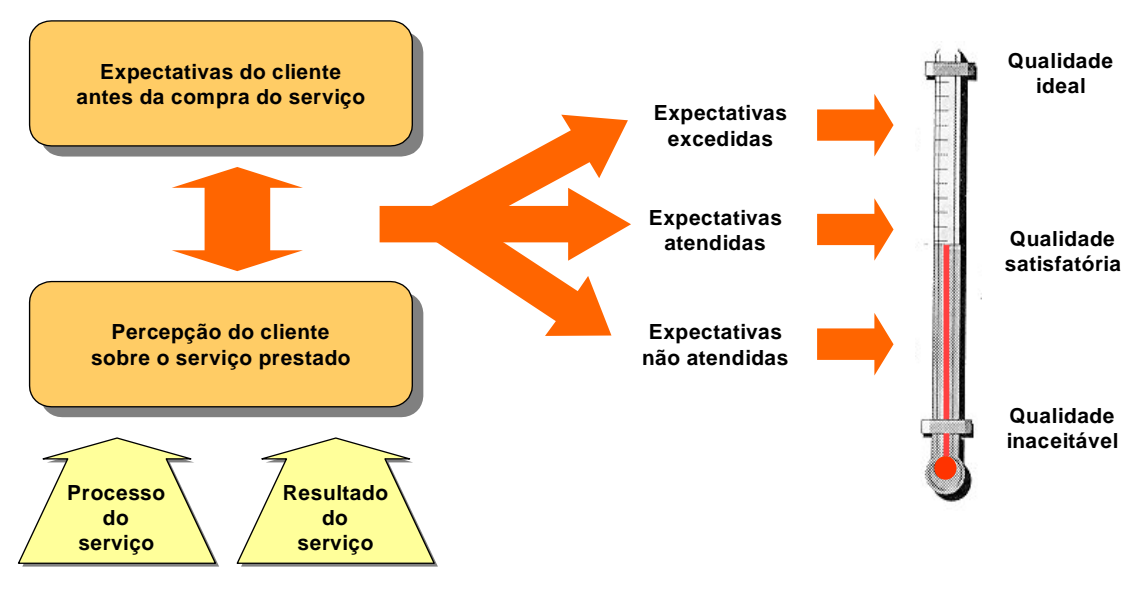

FIGURA 7. Avaliação da qualidade em serviços (adaptado de GIANESI \& CORRÊA: 1994) 
Este modelo da avaliação que o cliente faz do serviço, segundo GIANESI E CORRÊA (1994), é genérico e válido também para produtos, contudo ele é mais significativo para os serviços em função de sua intangibilidade. Quando o cliente vê um produto tangível, a imagem real é a principal responsável pela formação das expectativas do consumidor mesmo que seu anuncio seja exagerado. O que pesa é a imagem que o consumidor tem deste produto. Com relação aos serviços, por serem intangíveis, a formação das expectativas do cliente antes da compra não pode basearse em uma imagem real, dependendo, entre outros fatores da comunicação transmitida aos consumidores. Neste caso, se uma empresa ou um anunciante exagera na propaganda, isso pode gerar expectativas que excedem aquelas que poderão ser atendidas pelo fornecedor do serviço o que vai causar uma insatisfação por parte do consumidor. Por esse fator, o processo de compra de um serviço, em seu primeiro momento, confronta o desejo de satisfação de uma necessidade e a percepção de risco derivada da dúvida sobre a real capacidade do serviço em promover tal satisfação. O consumidor sente um risco maior na compra de um serviço em função da dificuldade em avaliar sua qualidade.

Surge, desta forma uma questão bastante polêmica na literatura. O que procurar atender, as necessidades ou as expectativas dos clientes?

Alguns autores defendem a hipótese de que o cliente se baseia em suas expectativas para avaliar a qualidade de um serviço, defendendo a idéia de que o fornecedor do serviço deve visar atender às expectativas do cliente e não suas necessidades. Outros autores preferem tratar do atendimento das necessidades dos clientes. Outros ainda, tratam ora de necessidades, ora de expectativas. 
Como os níveis de necessidades e de expectativas podem ser diferentes, que nível de exigência o sistema de operações de serviços deve estar preparado para atender?

Segundo GIANESI E CORRÊA (1995), inicialmente, pode-se considerar que as necessidades de um cliente são menos mensuráveis do que suas expectativas. Quando se aplica algum tipo de pesquisa, o que o cliente expõe são suas expectativas em relação a um serviço. Determinar as necessidades dos clientes pode envolver certo grau de julgamento de valor por parte do fornecedor do serviço que pretende identificá-las. Isso pode levar a equívocos se o fornecedor do serviço achar que sabe o que os clientes precisam, quando, em muitos casos, nem os próprios clientes sabem ao certo. O que os clientes sabem e conseguem transmitir é o que eles esperam do serviço. Neste caso, é mais fácil identificar as expectativas dos clientes do que suas reais necessidades.

GIANESI E CORRÊA (1995), apontam que pesquisas empíricas confirmam que os clientes utilizam suas expectativas para avaliar o serviço, ou seja, comparam o que esperavam com o que receberam. Deste modo, pelo menos em curto prazo, parece ser conveniente que o sistema de operações de serviço esteja preparado para identificar e atender às expectativas dos clientes mais do que suas necessidades.

\subsubsection{Momentos da verdade}

Os momentos de contato do fornecedor com o cliente observado pela característica de inseparabilidade, são também chamados de “momentos da verdade”. 
A percepção do cliente a respeito do serviço é formada em cada um dos momentos da verdade. Qualquer contato de um indivíduo com a organização que forme alguma impressão é considerado um momento da verdade.

Para determinar estes momentos da verdade é necessário identificar inicialmente todos os contatos que podem ser realizados por um cliente junto a algum aspecto da empresa, desde a aproximação até o pós-venda. A Figura 8 mostra um exemplo de um ciclo de serviço para um supermercado (GIANESI E CORREA, 1994: 87).

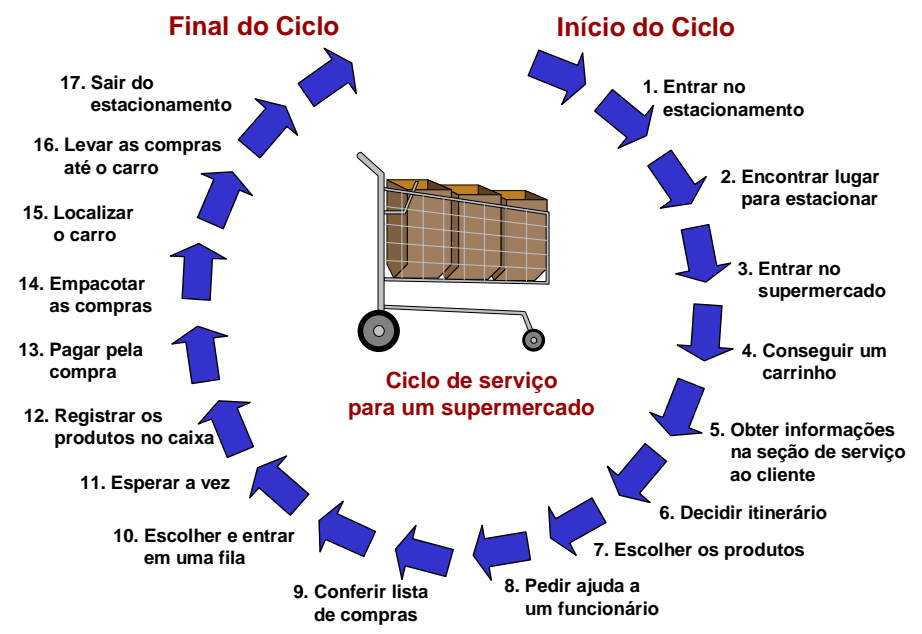

FIGURA 8. Ciclo de serviços para um supermercado (adaptado de GIANESI \& CORRÊA: 1994)

Nem todos os momentos da verdade têm a mesma importância para o cliente e há certos momentos da verdade críticos ou fundamentais para a percepção do cliente a respeito do serviço prestado. Isso faz com que o fornecedor pesquise estes momentos para que seu cliente possa ser atendido de forma satisfatória. 
Segundo GIANESI \& CORRÊA (1994), ao analisar qualquer ciclo de serviço, pode-se dizer que os primeiros e últimos momentos da verdade estão geralmente entre os críticos para a percepção do cliente. Nos primeiros momentos de contato o cliente irá ajustar sua percepção para o que poderá acontecer no restante do ciclo do serviço. A perspectiva ocorre nos poucos primeiros minutos do ciclo, e uma vez feito, fica difícil mudar a impressão do cliente quanto aquilo que vem depois. A impressão final que o cliente tem do serviço, formada nos últimos momentos, é também fundamental para sua percepção, pois permanece mais forte na memória, podendo influenciar sua decisão de repetir a compra, assim como na recomendação do serviço prestado para outros clientes.

Na verdade, os outros momentos do ciclo também são de fundamental importância para a percepção do serviço. Cada momento tem uma natureza diferente e critérios de avaliação diferentes onde o cliente os utiliza para fazer sua avaliação. Alguns destes critérios podem ter peso maior para o cliente, podendo-se dizer que os momentos da verdade críticos são aqueles em que estão em pauta elementos do serviço que afetam a percepção do cliente em relação a seus critérios de avaliação mais importantes (GIANESI \& CORRÊA, 1994).

Determinar os critérios que são utilizados pelos clientes para avaliar o serviço é condição fundamental para que o fornecedor do serviço possa priorizar seus esforços para gerar uma percepção favorável do serviço ao cliente.

Identificar os critérios segundo os quais seus clientes avaliam os serviços é uma forma do avaliador compreender melhor suas expectativas frente ao serviço prestado. A determinação destes critérios permite que a gestão das operações de serviço possa garantir o desempenho nestes critérios priorizados. 
Estes critérios de avaliação devem refletir os fatores que determinam a satisfação do cliente ou, em outras palavras, a qualidade do projeto e da prestação do serviço. É preciso um trabalho de pesquisa para saber realmente quais são os critérios mais importantes para o cliente, uma vez que podem ser tanto os serviços essenciais como os periféricos (secundários).

GIANESI \& CORRÊA (1994), apontam nove critérios de avaliação, que são:

- Tangíveis - qualidade ou aparência de qualquer evidência física do serviço ou do sistema de operações, ou seja, bens facilitadores, equipamentos, instalações;

- Consistência - significa conformidade com experiência anterior, ausência de variabilidade no processo;

- Competência - habilidade e conhecimento do fornecedor para executar o serviço, relacionando-se às necessidades técnicas dos consumidores;

- Velocidade de atendimento - Refere-se à prontidão da empresa em atender o cliente. Está relacionado ao tempo em que o cliente gasta para receber o serviço. Há diferença entre a dimensão real e a dimensão percebida pelo cliente.

- Atendimento/atmosfera - Refere-se ao grau de satisfação do cliente ao receber o serviço;

- Flexibilidade - Diz respeito à capacidade de mudança e adaptação da operação devido às necessidades dos clientes;

- Credibilidade/segurança - O cliente percebe o grau de risco do serviço. O fornecedor deve deixar seu cliente seguro quanto ao serviço, diminuindo sua percepção de risco; 
- Acesso - Este item avalia a facilidade do cliente entrar em contato com o fornecedor do serviço. Características como localização conveniente; acesso sinalizado, disponibilidade de estacionamento, horário da operação, linhas telefônica, entre outros contribuem para a facilidade de acesso.

- Custo - é o quanto o cliente irá dispor monetariamente para obter o serviço.

Após a identificação dos critérios de avaliação do serviço pelo consumidor, um outro fator de extrema importância para os serviços é a questão da avaliação da qualidade dos serviços prestados. Estes têm merecido muita atenção dos pesquisadores que têm procurado estabelecer modelos de qualidade em serviços que será descrito no item seguinte.

\subsection{Modelos da Qualidade em Serviços}

Este item trata de modelos desenvolvidos para avaliar a qualidade de serviços. São poucos e todos surgiram nas últimas décadas. Estes modelos explicam o relacionamento entre o comportamento do consumidor na percepção e avaliação dos serviços e os elementos que constituem o processo de oferta.

Para as empresas de serviços, segundo MENDES (1999), os modelos acentuam aspectos importantes relativos à qualidade de projeto (se o serviço realmente está baseado nos desejos dos consumidores), à qualidade da entrega (tempo, arranjo físico, segurança,etc), e à qualidade das relações pessoas envolvidas durante todo o processo de fornecimento do serviço. Portanto, os modelos da qualidade são instrumentos essenciais na gestão da qualidade dos serviços. 
Os modelos que fazem parte desta revisão são: o modelo de Gummesson, o modelo de Gronroos, o modelo de Gummesson \& Gronroos e o modelo de Parasuraman, Zeithalm \& Berry.

\subsubsection{O modelo de Gummesson}

GUMMESSON (1987), identificou quatro tipos de qualidade como origens de qualidade percebida e satisfação do cliente: qualidade do projeto, qualidade de produção, qualidade de entrega e qualidade relacional. Seu modelo ainda considera expectativas, experiências e imagem, como fatores que influem diretamente na avaliação feita pelo consumidor, conforme mostra a Figura 9.

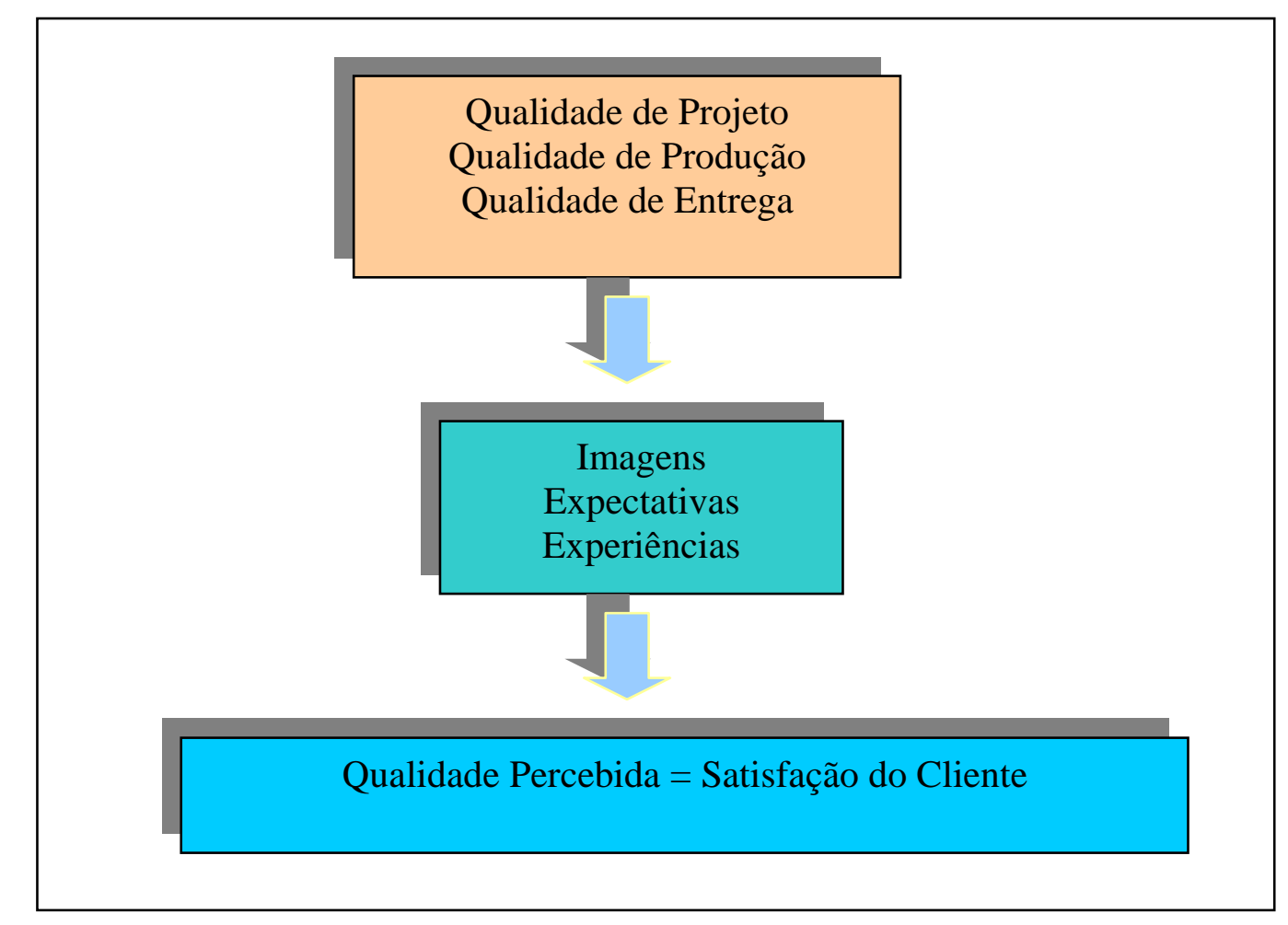

FIGURA 9. Modelo de Gummesson. 
As três primeiras dimensões da qualidade apresentadas no modelo já faziam parte da qualidade de bens há bastante tempo, porém, a qualidade relacional foi uma inovação conceitual de Gummesson, inspirado na administração de serviços, segundo LABEGALINI (1997). Refere-se ao grau de sucesso na criação de relacionamentos externos com clientes e relações internas na organização, sendo afetada diretamente pela qualidade de produção e qualidade da entrega. Neste caso, dois componentes formam a qualidade relacional: relacionamento profissional e relacionamento social.

GUMMESSON (1987), entende que a qualidade é a soma de todas as coisas feitas desde a concepção de uma idéia até a sua entrega ao cliente. Duas condições devem estar presentes para a consecução da qualidade:

- A condição de especialista, onde cada qual deve cumprir suas atribuições adequadamente na organização; e

- A condição de integração, onde cada empregado desenvolve um relacionamento de cliente-fornecedor.

A qualidade de projeto e a qualidade relacional são mais diferenciadas do que as outras duas que nem sempre podem ser distintamente estabelecidas devido à simultaneidade de produção e consumo. A imagem também influi na avaliação do cliente. Se a imagem for positiva, as falhas no serviço podem até ser consideradas acidentais mas, se negativa, o efeito de um pequeno erro pode ser bastante ampliado na avaliação da qualidade, afetando as expectativas e gerando insatisfações.

Desta forma, imagem, expectativas e experiências, de um lado, e as qualidades de projeto, produção, entrega e relacional de outro, formam o modelo 
de qualidade de Gummesson que atua diretamente na qualidade interna (empregados podem contribuir com os resultados) e na qualidade externa (total satisfação do cliente).

\subsubsection{O modelo de Gronroos}

GRONROOS (1990), enfatizou a qualidade percebida pelo cliente e verificou que suas expectativas baseavam-se em duas vertentes, a qualidade técnica e a qualidade funcional. Seu modelo pode ser melhor apreciado na Figura 10.

A qualidade técnica corresponde à qualidade do conceito de serviço (quais são os elementos que compõem o pacote de serviço, quais são seus clientes, como e com que recursos são produzidos e quais são os benefícios para os clientes?) e o cliente avalia o resultado final do processo e a qualidade funcional. Avalia mais subjetivamente a maneira como a qualidade técnica foi transferida através do desempenho de tarefas, informações prestadas etc.

A qualidade total resulta da comparação entre a qualidade esperada e a qualidade experimentada, e não apenas do nível dos componentes de qualidade técnica e funcional.

Assim como no modelo de Gummesson, Gronroos enfatiza a importância da imagem, que por um lado influencia a percepção de qualidade do cliente e, por outro, age como um filtro que irá selecionar os fatores influenciadores da qualidade.

Apesar das duas definições terem grande importância para a empresa, nada significam para o consumidor uma vez que este avalia a qualidade como um todo. 
Assim, prestadores de serviços devem adotar políticas que garantam a qualidade técnica e funcional a partir das expectativas dos clientes, segundo MENDES (1999).

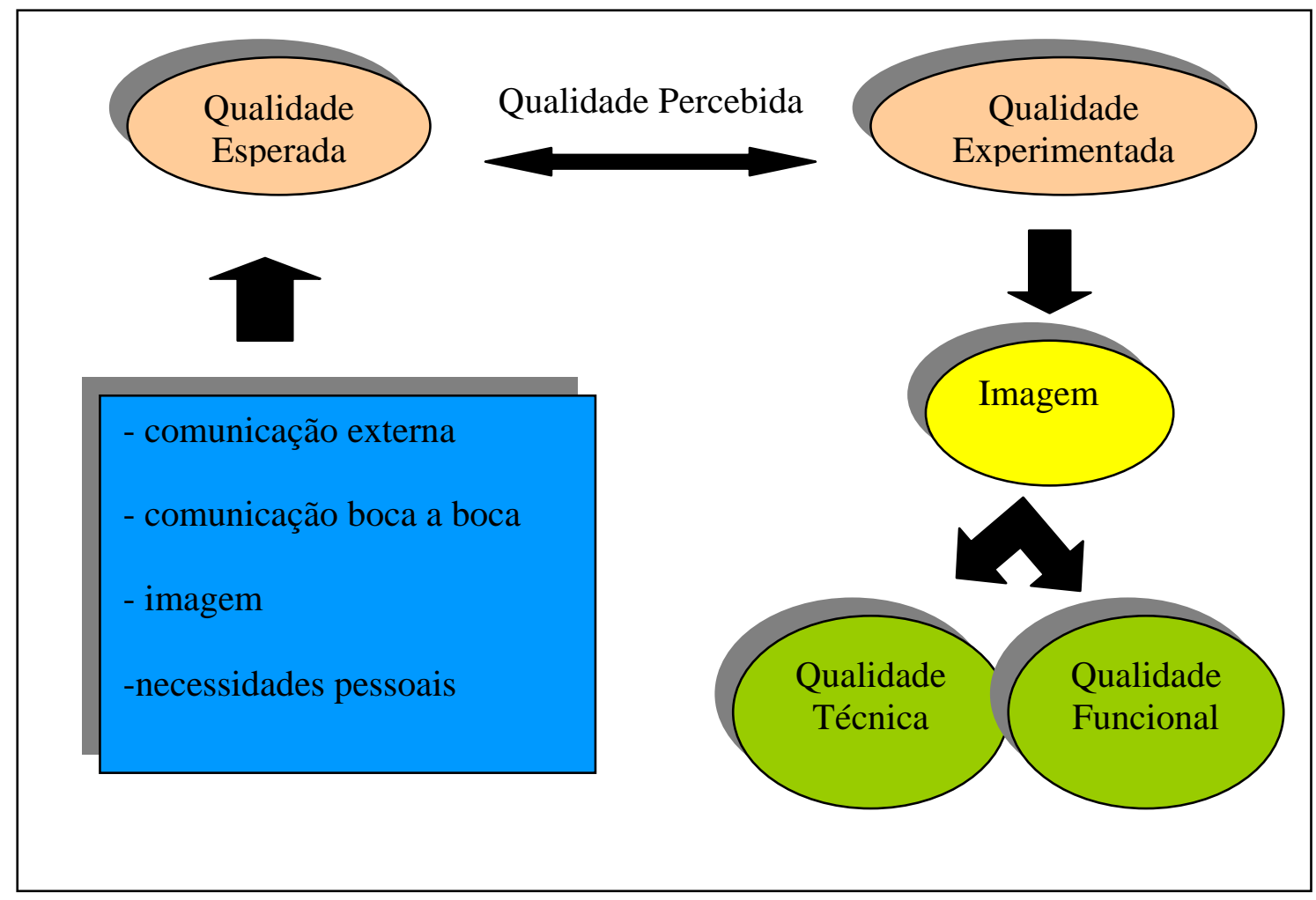

FIGURA 10. Modelo da Qualidade de Serviço de GRONROOS.

\subsubsection{O modelo de Gummesson \& Gronroos}

GUMMESSON \& GRONROOS (1988) neste modelo, além de investigarem os relacionamentos existentes na avaliação da qualidade, se preocuparam em determinar como a qualidade do serviço é criada. Os autores uniram seus modelos em um só. Este modelo apresenta a qualidade percebida pelo cliente segundo dois 
componentes: o par qualidade técnica e funcional e as quatro fontes de qualidade, projeto, produção, entrega e relacional.

A qualidade do projeto compreende as atividades de identificação das expectativas dos clientes, a tradução destes em atributos do serviço e o desenvolvimento do processo de prestação segundo as características do serviço e o desenvolvimento do processo de prestação segundo as características do serviço e das expectativas relacionadas ao sistema de prestação de serviço (vide Figura 11).

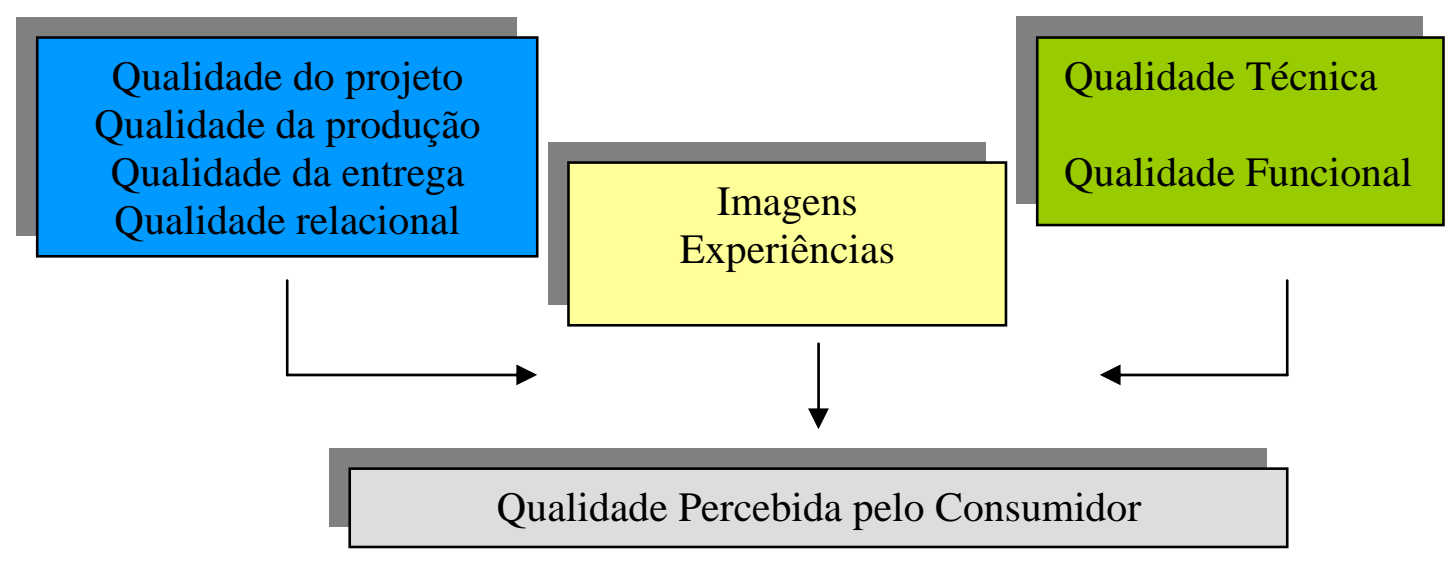

FIGURA 11. Modelo da Qualidade em Serviços de Gronroos-Gummesson. GRONROOS (1995:86).

\subsubsection{O Modelo de qualidade em serviços de Parasuraman, Zeithalm \& Berry}

PARASSURAMAN et al. (1990), criaram o modelo das cinco falhas, demonstrado na Figura 12. Este modelo foi desenvolvido a partir de pesquisas e entrevistas com diretores, gerentes e consumidores de quatro diferentes ramos do 
setor de serviços: bancos, seguradoras, empresas de cartão de crédito e empresas de reparo e manutenção de bens. Sua principal característica é a identificação de lacunas entre um certo número de fenômenos da qualidade de serviços. É considerado o mais consistente modelo de qualidade em serviços e recebe este nome por ter identificado cinco falhas ou discrepâncias (gaps) entre o sistema de prestação de serviço e a qualidade esperada pelo consumidor, o que resulta em problemas na percepção da qualidade.

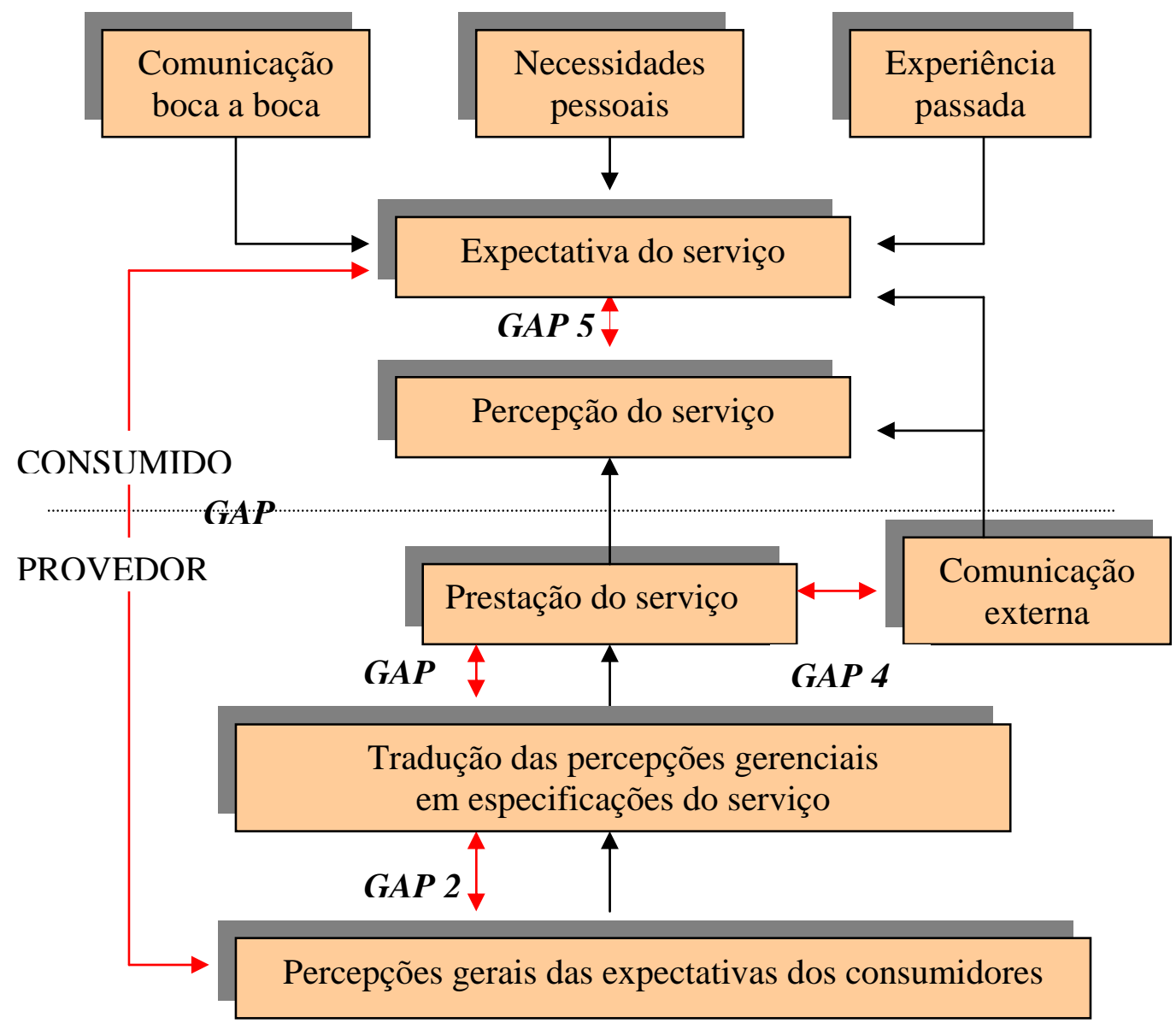

FIGURA 12. Modelo da Qualidade em Serviço de Parasuraman, Zeithalm \& Berry. 
Após entrevistas feitas com os executivos destas empresas, PARASURAMAN et al. (1990) perceberam que existem quatro lacunas (gaps) entre a percepção da qualidade de serviço dos executivos e as diversas tarefas do processo até a entrega de um serviço ao cliente. As lacunas são:

- expectativas dos clientes X percepção das expectativas pela gerência;

- percepção das expectativas pela gerência X especificações da qualidade do serviço;

- especificações da qualidade do serviço X serviço realmente entregue;

- serviço prestado X comunicações externas.

Surgiu também em seguida, a quinta lacuna do modelo que relacionava o serviço esperado e o serviço percebido pelo cliente, influindo diretamente no julgamento final da qualidade.

Mais especificamente, a primeira das lacunas citadas (gap1), refere-se às expectativas dos clientes e à percepção da gerência frente a estas expectativas sobre determinado serviço. Nem sempre as necessidades e expectativas dos clientes são percebidas pelo provedor. Os executivos muitas vezes não sabem quais os requisitos que conotam alta qualidade para os consumidores, quais as características que os serviços devem conter para ir de encontro às necessidades dos clientes e quais níveis de desempenho destas características configuram alta qualidade no fornecimento.

Algumas medidas para se prevenir falhas deste tipo, segundo MENDES (1999) são: efetuar pesquisas constantes, influir na formação das expectativas, identificar as dimensões de qualidade consideradas importantes para o tipo do cliente, desenvolver uma cultura de serviços, entre outros. 
A segunda lacuna (gap2), diz respeito à tradução em especificações de fornecimento, da percepção da gerência em relação às expectativas dos clientes. O desentendimento destas expectativas não está no desconhecimento dos sentimentos dos clientes, e sim em fatores que impedem a especificação da oferta ajustada aos desejos dos consumidores. Em outras palavras, o sistema de prestação de serviços desenvolvido não consegue atender às necessidades e às expectativas dos clientes, em virtude da escassez de recursos, condições de mercado ou deficiência gerencial. Entre as causas da ocorrência do gap 2, os autores apontam a falta de comprometimento da gerência com a questão da qualidade, uso inadequado de sistemas de padronização e o não estabelecimento de metas para o processo de fornecimento.

A terceira lacuna (gap3) salienta o fato dos prestadores de serviço serem incapazes de desempenhá-lo no mesmo nível projetado pela gerência. Isso pode ocorrer devido a regras ambíguas ou conflitantes, supervisão inadequada, tecnologias de trabalho ultrapassadas, falta de treinamento, iniciativa ou poder de decisão, entre outros. São falhas humanas que podem ser minimizadas através de valorização da mão-de-obra, na melhoria da prestação de serviços pelo uso de políticas de treinamento, motivação e seleção de pessoal melhor qualificado, entre outros. Neste momento, ocorre o contento do cliente com o prestador de serviço.

A quarta lacuna (gap4) aponta que as discrepâncias entre, a entrega do serviço e as comunicações externas têm um forte impacto na percepção do cliente sobre a qualidade do serviço. É a lacuna entre a promessa do serviço e o serviço fornecido. Nesta lacuna salienta-se a inadequada comunicação horizontal entre a operação, o marketing e o serviço prestado. Os diversos canais da mídia, como 
propaganda e os outros tipos de comunicação como o boca a boca, afetam as expectativas dos clientes. Se as expectativas têm todo este poder, a empresa deve saber que corre riscos ao fazer promessas sem poder cumpri-las, não pode, desta forma, supervalorizar as expectativas do cliente pois isso irá gerar perda do cliente e prejuízos à imagem da empresa.

A quinta lacuna (gap5) foi estabelecida como uma função das quatro lacunas anteriores, gap5=f/ (gap1, gap2, gap3, gap4) na qual indica que a qualidade percebida pelo consumidor, que depende das lacunas associadas ao projeto, marketing e fornecimento, serão comparadas as expectativas que ele tinha sobre o serviço (que seria prestado) (REBELATO, 1995). Deste modo, as informações que o cliente possui a priori, serão utilizadas na orientação da qualidade,m e por essa razão é dependente dos outros gaps.

A partir dos gaps , PARASURAMAN, ZEITHAML E BERRY (1990) criaram um instrumento para avaliar a percepção dos clientes a respeito da qualidade do serviço, que denominaram SERVIQUAL, contendo cinco critérios:

- Tangíveis - representam a aparência dos funcionários e dos materiais, instalações físicas, equipamentos, percebidos pelos clientes;

- Confiabilidade - prestação do serviço de forma confiável, precisa e consistente;

- Responsividade - disposição para prestar o serviço prontamente e auxiliar os clientes;

- Confiança - conhecimento dos funcionários e sua habilidade de transmitir confiança, segurança e credibilidade; 
- Empatia - atenção individualizada aos clientes, facilidade de contato e comunicação.

Segundo MENDES (1999), os modelos da qualidade são ferramentas gerenciais que permitem, aos administradores do setor, melhor entendimento da percepção da qualidade do serviço, resultado da comparação entre as expectativas formuladas pelo cliente e sua percepção. O modelo das cinco falhas direciona a análise das fontes destes problemas da qualidade e indicação de meios para melhorá-las. Esses instrumentos são de ampla aceitação e podem ser usados em qualquer ramo dos serviços, já que focalizam princípios gerais relativos à criação e à prestação de qualquer serviço.

\subsection{As dimensões da qualidade em serviços e os níveis de tolerância do consumidor}

Em pesquisa feita por PARASURAMAN et al. (1991) através de entrevistas com dezesseis grupos de consumidores em seis setores de serviços (seguro de automóveis, reparações de equipamentos comerciais, seguro de propriedade comercial e acidentes, aluguel de caminhões e tratores, reparação de automóveis e hotéis), os autores sugerem que as expectativas dos consumidores manifestam-se em dois níveis: o desejado e o adequado. O nível de serviço desejado é aquele em que os consumidores apontam o que esperam receber. O nível de serviço adequado é aquele em que o consumidor considera admissível mas que está abaixo do nível 
desejado. Entre o nível desejado e o nível adequado, tem-se a zona de tolerância, que estabelece a faixa aceitável pelo consumidor, conforme aponta a figura ...

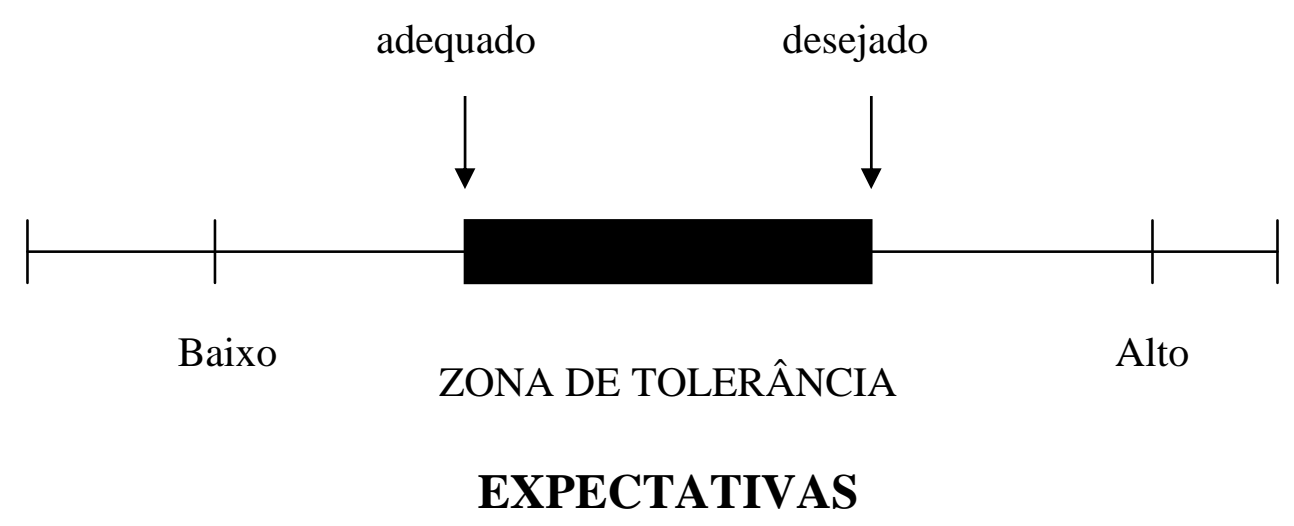

FIGURA 13. Níveis de expectativas dos serviços

Os consumidores encaram a confiabilidade como a mais importante das dimensões e que está diretamente relacionada com o resultado do serviço. A confiabilidade seria o ingrediente básico para alcançar-se as expectativas dos consumidores. As outras dimensões têm um grau secundário de importância e estão diretamente relacionadas não com o resultado mas com o processo do fornecimento. Estas dimensões seriam uma forte arma para se exceder às expectativas dos consumidores.

Um fator que pode elevar o nível de serviço desejado é a experiência do consumidor. Se um consumidor é muito experiente em determinado tipo de serviço ele tende a desejar mais aquele serviço. O primeiro contato do consumidor com o com o serviço difere das experiências de consumo posteriores. Desta forma, as 
expectativas e tolerâncias do consumidor ao experimentar o serviço pela primeira vez, são mais brandas.

Os consumidores também são fortemente influenciados por outros consumidores e este fato pode elevar as expectativas do nível de serviço desejado.

O nível de serviço adequado, diferentemente do nível de serviço desejado, parece ser influenciado por circunstâncias mais específicas e ser mais variável. Uma influência determinante sobre o nível adequado é o número de serviços alternativos percebidos pelo consumidor. Se o consumidor tem fornecedores alternativos à sua disposição, o nível de serviço adequado sobe, reduzindo então a zona de tolerância. Outro fator que eleva o nível de serviço adequado é: situações de emergência ou situações de falhas durante o fornecimento. 


\section{CAPÍTULO 5}

UMA ESTRUTURA DE REFERENCIA PARA INVESTIGAR A QUALIDADE NO ENSINO DE ENGENHARIA SOB A ÓTICA DE SERVIÇOS

\subsection{A qualidade do ensino de engenharia}

Consensualmente, qualidade é o resultado de ações competentes implementadas institucionalmente, dentro de um planejamento global, sistemático e objetivo. Assim sendo cabe às organizações comprometidas com o ensino de engenharia, empenhar-se estrategicamente, canalizando atenção na busca da melhoria da sua qualidade institucional e da qualidade de seus esforços.

Segundo COLENCI JR. (1996), a Engenharia de Produção há décadas descobriu que qualidade é resultado de uma organização sadia e capaz de garanti-la, em níveis compatíveis de qualidade. Em função disso, já não se aplica controle de qualidade no fim da linha de produção, para se detectar que determinado produto carro ou geladeira - está rejeitado. Ao contrário, investe-se na organização, implementando suas condições de forma sistemática e competente, ao longo de toda cadeia de fornecimento para se produzir certo na primeira vez, visto que qualquer forma de retrabalho ou rejeição, por si só seria onerosa e descabida. 
No caso do ensino de engenharia, a situação se reveste de alta complexidade, pois além do respeito humano, cabe a responsabilidade civil pelo pleno desenvolvimento educacional e profissional do estudante. As práticas pedagógicas e a experiência permitem estabelecer um conjunto de condições que se cumpridas assegurarão uma certa qualidade nos resultados. O controle da qualidade "a posteriori”, conforme já exposto, é tardio e oneroso, pois não se pode simplesmente rejeitar um recém-formado ou colocá-lo na prateleira como estoque. O melhor é controlar preventivamente as condições sob as quais se realizam as tarefas e estabelecer uma organização competente para garanti-las.

Neste caso, o primeiro ponto a se avaliar seria a qualidade estudada previamente, isto é, durante o processo e o segundo ponto seria analisar a forma como esta avaliação deve ser feita segundo um contexto estrategicamente estabelecido.

A questão da qualidade do ensino, tem sido geralmente analisada levando-se em conta pontos fragmentados, pois ora se enfoca a perspectiva dos alunos, ora a perspectiva do professor, ora o conteúdo do ensino e ora a sua organização (UFMG, 1982).

Os trabalhos que avaliam a qualidade do ensino através do corpo discente usam como indicadores, notas de exames vestibulares, antecedentes escolares, freqüência e evasão, desempenho escolar, aprovação e reprovação, entre outros.

Outros trabalhos dão ênfase ao corpo docente. Neste caso, os indicadores são, titulação de professores, regime de trabalho, cursos de extensão e metodologia etc. 
Há ainda os que salientam o próprio ensino, dos quais são indicadores, os currículos e programas, carga horária, objetivos etc.

Estes trabalhos, no entanto, não atingem a essência da situação da qualidade do ensino uma vez que apresentam visões parciais da questão.

Em vista disso, questiona-se: um curso universitário oferece um ensino de boa qualidade com base na freqüência dos alunos, nos títulos dos professores ou pela alta ou baixa carga horária? É possível afirmar que as respostas a estas e outras questões, apesar de relevante importância, não são suficientes para garantir a qualidade do ensino.

Os elementos do ensino devem ser compreendidos em sua totalidade. A essência da qualidade não pode ser captada a partir de partes fragmentadas, em análises isoladas, a menos que estas partes fragmentadas façam parte do todo e permitam uma análise sintética de todas as partes.

Neste caso, o trabalho procurou analisar o ensino de engenharia sob um novo enfoque, não mais à imagem da manufatura e sim sob a ótica de serviços para, assim, identificar os clientes e suas necessidades e mais, através dos modelos de avaliação de qualidade, analisar o ensino em sua totalidade, e não mais em partes fragmentadas, apontando as lacunas do sistema.

\subsection{O ensino de engenharia sob a ótica de serviços}

O ensino, como uma forma de prestação de serviços é um fenômeno complexo sujeito à intervenção de um grande número de variáveis para alcançar 
mudanças intelectuais, comportamentais, psicomotoras e outras, em indivíduos que são objetos de sua ação (COLENCI JR, 1994). Além disso, cabe reforçar que o serviço com qualidade representa forte embasamento para a vantagem competitiva conforme salientam ALBRECHT \& BRADFORD (1992).

Uma das melhores maneiras de instrumentalizar o processo educacional, proposta que o trabalho defende, de associar sua prática ao contexto de desenvolvimento de serviços.

De acordo com PORFÍRIO (1992), são as opções decorrentes da reflexão em torno do como educar que tornam a ação didática, não uma atividade rotineira, repetitiva, desligada da realidade e constituída por uma coleção de elementos soltos, mas, ao contrário, um projeto pedagógico coerente e articulado com as intenções educativas. É a concepção e a realização desse projeto que, se por um lado traz novas exigências aos professores, por outro, justifica o entendimento da atividade docente como algo que não se esgota no ensino e na instrução, mas se orienta para desencadear a formação, o desenvolvimento e a educação dos alunos, sua aprendizagem.

Ao assimilar a prática educativa como uma atividade de serviços, altera-se o enfoque do ensino para a aprendizagem pois se tem o cliente como agente principal do processo, isto é, como sendo ele um dos principais beneficiados pelos serviços prestados entre outros, pelo professor. No caso, o aluno é visto aqui como o cliente (usuário) da educação.

Na Tabela 3 pode-se constatar a semelhança entre serviços e educação. 
TABELA 3 - A educação como uma das manifestações de serviço.

\begin{tabular}{|c|c|}
\hline & ÃO \\
\hline $\begin{array}{l}\text { (os serviços não podem } \\
\text { ser tocados, são } \\
\text { experiências vividas) }\end{array}$ & $\begin{array}{l}\text { - A educação é intangível pois são experiências que os } \\
\text { atores vivenciam. Esta intangibilidade dificulta ao } \\
\text { diretor, aos professores, a sociedade e o próprio } \\
\text { aluno a possibilidade de bem avaliar o resultado e a } \\
\text { qualidade da educação. A educação é de difícil } \\
\text { padronização, o que torna a gestão do processo mais } \\
\text { complexa. }\end{array}$ \\
\hline $\begin{array}{l}\text { - Necessidade da } \\
\text { presença do cliente } \\
\text { (O cliente é quem } \\
\text { dispara a operação em } \\
\text { termos de quando e } \\
\text { como esta deve realizar- } \\
\text { se. O cliente é tratado } \\
\text { pelo sistema). }\end{array}$ & $\begin{array}{l}\text { - No caso da educação, há um questionamento a } \\
\text { respeito de quem é o verdadeiro cliente da educação: } \\
\text { os alunos, a sociedade, as empresas ou todos eles? } \\
\text { SIRVANCI (1996). E hoje, com a questão da } \\
\text { tecnologia discute-se a necessidade da presença física } \\
\text { face à educação à distância pelo menos em algumas } \\
\text { atividades. }\end{array}$ \\
\hline $\begin{array}{l}\text { - Os serviços são } \\
\text { produzidos e } \\
\text { consumidos } \\
\text { simultaneamente }\end{array}$ & $\begin{array}{l}\text { - Não há na educação uma etapa intermediária entre o } \\
\text { conhecimento e sua assimilação. Ao mesmo tempo } \\
\text { em que o conhecimento é dado, deve ser assimilado. } \\
\text { Pelo menos no que tange a atividade em sala de aula } \\
\text { (ensino-aprendizagem e demais relações professor- } \\
\text { aluno). }\end{array}$ \\
\hline $\begin{array}{llr}\text { - } & \text { Os serviços } & \text { não } \\
& \text { podem } & \text { ser } \\
& \text { estocados } & \end{array}$ & $\begin{array}{l}\text { - A questão que pode ser aqui colocada refere-se à } \\
\text { possibilidade de se “estocar conhecimento", na forma } \\
\text { de estruturas mentais e não em fragmentos } \\
\text { armazenados para posterior recuperação e aplicação. }\end{array}$ \\
\hline $\begin{array}{l}\text { - Os serviços são } \\
\text { altamente variáveis }\end{array}$ & $\begin{array}{l}\text { - A educação varia de pessoa para pessoa, deve ser } \\
\text { individualiza. }\end{array}$ \\
\hline
\end{tabular}


Assim como em serviços, na educação pode-se constatar os momentos da verdade. Mas nem todos os momentos têm a mesma importância para os envolvidos. Geralmente, em serviços, os primeiros e os últimos momentos são os mais importantes para o cliente. Na educação ocorre o mesmo. No caso do aluno do curso superior, um momento importante é quando ele entra na universidade e o outro é quando sai, apto para desenvolver novas habilidades requeridas pelo mercado de trabalho e pela sociedade. Isso não significa que os momentos entre a entrada e a saída não sejam importantes. Significa que se eles forem feitos com qualidade atingirão a finalidade de prepará-lo para sua vida profissional e social.

Assim caberá ao professor, no desenvolvimento do aprendizado, utilizar adequadamente o poder de decisão que possui e o tempo de intervenção que tem junto aos alunos, para atuar segundo o projeto educativo do qual participa e os conceitos metodológicos que o orienta, para o alcance de adequados resultados. Nas circunstâncias atuais, um novo paradigma passa a reger o processo educacional integrando novas dimensões:

- da concepção e comunicação;

- do exercício, da aplicação e do aperfeiçoamento de habilidades (skill);

- da aquisição de sensibilidade quanto às decisões (feeling);

- da execução e do controle;

neste sentido, dando lugar a uma ação inteligentemente estruturada e organizada quando da intervenção do profissional. (COLENCI JR, 1994). 


\subsubsection{O projeto pedagógico}

As instituições de ensino de engenharia devem se dedicar ao estabelecimento de um projeto pedagógico com a visão holística e sistêmica de modo a contemplar as diversas etapas de atuação. Esse projeto deve apresentar os resultados de uma reflexão sobre a missão, objetivos e metas institucionais e principalmente sobre as necessidades dos beneficiários do serviço.

Neste contexto onde se analisa a educação sob o enfoque de serviços, foi utilizado um modelo para que se possa identificar quais são as relações existentes no contexto educacional e os gaps ou falhas que o ensino vem apresentando em sua estrutura, isto é, quais são as deficiências que prejudicam a qualidade do ensino de engenharia. Este modelo será abordado a seguir.

\subsection{A estrutura de referência proposta}

O modelo de PARASURAMAN, ZEITHAML E BERRY (1990), como já mencionado é considerado como sendo o mais consistente modelo de qualidade em serviço e recebe o nome de "modelo das cinco falhas" por ter identificado cinco falhas ou discrepâncias (gaps) entre o sistema de prestação de serviços e a qualidade esperada pelo consumidor, redundando em problemas na percepção da qualidade.

Pela forma como foi concebido, esse modelo considera, de forma sistêmica, todas as variáveis que podem influenciar a qualidade e a interação entre elas. Considerando esses aspectos e sua generalidade é que foi considerada a adaptação 
desse modelo, pensando na sua utilização na educação, particularmente no ensino de engenharia onde se pode analisar a qualidade de forma holística.

Para que a aplicação seja possível, é preciso proceder à adaptação das variáveis originais, para melhor representar as situações com que se depara o ensino de engenharia.

Para um melhor entendimento das relações complexas existentes na educação em engenharia, será proposta uma estrutura de referência para se avaliar a qualidade em três níveis diferentes de relações: estratégico, tático e operacional, representados na Figura 14.

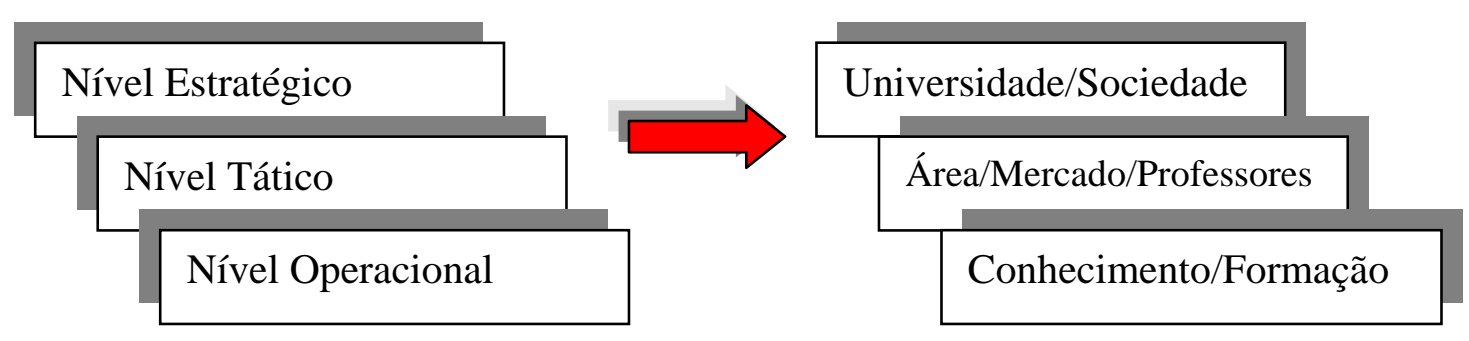

FIGURA 14. Diferentes níveis de relações de prestação de serviços educacionais.

O nível estratégico, segundo BELHOT (1996) está envolvido com as interações das atividades da organização e seu ambiente. Neste contexto, avalia-se a relação universidade/sociedade. Entende-se estratégia como o padrão das decisões e ações resultantes do desdobramento da visão de longo prazo da organização, influenciada por fatores internos e externos, levando-se em conta dois aspectos:

- As escolhas estratégicas moldam a estrutura e processos da organização;

- A estrutura e os processos condicionam a estratégia. 
O nível tático é o nível intermediário, que coordena e integra as tarefas do nível operacional junto ao nível estratégico. Neste nível, integram-se as entradas para o nível operacional. No caso, é a relação de determinada área de conhecimento com o mercado, com os professores e as disciplinas.

O nível operacional refere-se à execução das atividades operacionais, isto é, está relacionado às atividades de desenvolvimento do processo de conhecimento e de formação do aluno a partir dos recursos humanos, materiais e tecnológicos disponíveis.

Apesar de feita esta delimitação, nada impede que se analisem as relações entre os diferentes níveis, por exemplo, da universidade com o aluno; da área de engenharia com o professor da disciplina pois há sempre uma relação a ser analisada. O importante é que se determine, no momento da análise, quem está prestando o serviço e quem está se beneficiando, ou seja quem é o cliente e quem é o prestador. Em seguida, deve-se especificar quais as expectativas do cliente, quais suas experiências, entre outros aspectos. Espera-se que essa divisão possa identificar as ações a serem empreendidas a cada nível e assim contribuir para um melhor entendimento do processo educacional.

\subsubsection{Adaptação do modelo nos diferentes níveis}

Adaptação 1: Nível estratégico 
Tomando-se por base a relação universidade/sociedade e adaptando o modelo pode-se chegar à relação especificada na Figura 15.



FIGURA 15. Adaptação do Modelo da Qualidade em Serviço de Parasuraman, Zeithalm \& Berry para o nível estratégico.

O alcance da excelência na qualidade em serviços está diretamente vinculada à capacidade de traduzir os valores dos clientes em serviços com alto valor agregado. Tendo como foco de análise a Figura 15, encontra-se do lado de cima da 
figura, retângulos com as necessidades provenientes da sociedade que neste ponto é vista como o beneficiário do serviço prestado pela universidade que apresenta suas funções nos retângulos da parte de baixo da figura.

Em cada retângulo é apresentado um ponto onde há a necessidade de se pensar em qualidade e entre eles um gap ou lacuna na prestação do serviço que impede o efetivo alcance da qualidade. A seguir será explicado cada retângulo respectivamente.

1. Esse retângulo refere-se às expectativas da sociedade e à percepção da universidade frente a essas expectativas. É essencial que a universidade conheça as expectativas da sociedade onde atua para que possa efetivamente contribuir para o desenvolvimento e melhoria social. Essa melhoria diz respeito à formação de valores morais e éticos nos profissionais que irão atuar nesse ambiente, ao conhecimento aplicado em questões sociais e a própria educação básica pois muitos professores de $1^{\circ}$ e $2^{\circ}$ graus são formados pelas universidades.

2. Refere-se à concepção do modo como a universidade responde às expectativas da sociedade. Depois de medidas as expectativas, a universidade deve atuar para responder às expectativas previstas. Neste ponto é necessário refletir sobre o papel da universidade e o tipo de serviço que presta.

3. Este item refere-se à atuação da universidade em si, à forma como ela presta o serviço. Além dos cursos universitários, a universidade oferece cursos de especialização, extensão e ainda presta serviços à comunidade, abrindo o campus, 
promovendo eventos. A universidade deve levar em conta a relação custo benefício, o que vai proporcionar em troca do dinheiro gasto além de uma minoria qualificada.

4. Os meios de divulgação são uma forma de estratégia de marketing que fazem com que o beneficiário do serviço, no caso a sociedade, entre em contato com o que a universidade pode oferecer. Geralmente as universidades particulares se utilizam muito deste meio para atrair maior demanda. Para elas é interessante maior número de beneficiários uma vez que ela cobra por seus serviços, diferentemente da universidade pública que apresenta demanda maior que a oferta.

5. Com a prestação do serviço, a universidade deve atender tanto as expectativas da sociedade como suas necessidades. As necessidades do cliente são o principal fator formador de suas expectativas já que é visando atender essas necessidades que os clientes procuram o serviço. Neste caso, a universidade deve ficar atenta às necessidades que a sociedade apresenta em função do serviço a ser prestado.

6. Este item está ligado com os anteriores pois diz respeito às expectativas das necessidades atuais e futuras da sociedade. De que forma esta expectativa é gerada? Ela está relacionada com os itens 7, 8 e 9 que dizem respeito às necessidades nacionais ligada a valores que a sociedade requer dos cidadãos, às experiências passadas que a sociedade teve com a universidade e conseqüentemente à demanda de novos alunos selecionados através do vestibular, que irá mostrar a procura e o 
interesse pelo curso oferecido. As expectativas da sociedade são geradas a partir do contato que ela teve com os serviços prestados pela universidade no passado e com a satisfação desses serviços. Desta forma, a demanda e o interesse para que ela continue a se interessar pelos serviços depende da experiência satisfatória do passado mesmo porque a universidade pública é mantida com recursos de toda a comunidade e se faz necessário um serviço prestado com qualidade.

Explicado cada ponto a se pensar em qualidade, surgem então os gaps ou lacunas entre cada um desses itens. São falhas na prestação do serviço entre o próprio sistema de prestação do serviço e a qualidade esperada pelo consumidor, o que traz problemas na percepção da qualidade. Quanto maior à distância entre os retângulos maior será a lacuna apresentada.

O gap1, é uma discrepância entre as necessidades e expectativas da sociedade e a própria percepção da universidade frente a essas expectativas. Suas causas residem na insuficiência de pesquisas, da baixa interação entre universidade e sociedade. Neste ponto pergunta-se: Atualmente essa expectativa é conhecida pela universidade? Foi medida? De que forma? Para qual fim?

O gap2, diz respeito à lacuna existente entre a percepção da universidade frente às expectativas da sociedade e a concepção do modo como a universidade responde a essas expectativas. Qual o seu papel? Que tipo de serviço presta? É interessante observar nesse momento, qual o ponto de referência que a universidade utiliza para tomar decisões. Ela tem esse referencial, se utiliza dele para tomar decisões? Existem restrições que impedem a demanda se ajustar à oferta? Como é feita a transformação das percepções em especificações? Como se adapta o currículo, o método, técnicas, recursos etc? Como é feito o planejamento de ensino? Como ela 
sabe que determinado curso é importante e qual ênfase deve ter? Há diferenças entre universidades públicas e particulares?

O gap3 encontra-se entre a concepção do modo como a universidade responde às expectativas da sociedade e a sua própria atuação. Por exemplo, os cursos de especialização, extensão e prestação de serviços à comunidade estão atingindo seus objetivos ou precisam ser revistos? De que forma isso poderia ser melhorado em termos de pesquisa, ensino e extensão?

No gap4 é preciso identificar quais estratégias de marketing estão sendo utilizadas. Mas é preciso salientar que se essas estratégias não estiverem de acordo com o serviço a ser prestado e se excederem, isso causará um certo tipo de frustração nos beneficiários o que será prejudicial à prestação do serviço. Pergunta-se: Quais os veículos? Para atingir quais clientes? Considerando os vários recursos tecnológicos e as diferentes mídias, a divulgação da universidade deve ser pensada e praticada inclusive para mostrar à sociedade os serviços prestados. Este gap se encontra entre as estratégias e a própria prestação do serviço.

O gap5 é uma função dos outros gaps. A sociedade irá associar o serviço a experiências passadas, com as necessidades que ela aponta, no caso melhoria da educação de uma forma global. A discussão dos investimentos nela feito, passa a ser avaliada. Como demonstrar a relação custo/benefício? 
Adaptação 2: Nível tático.

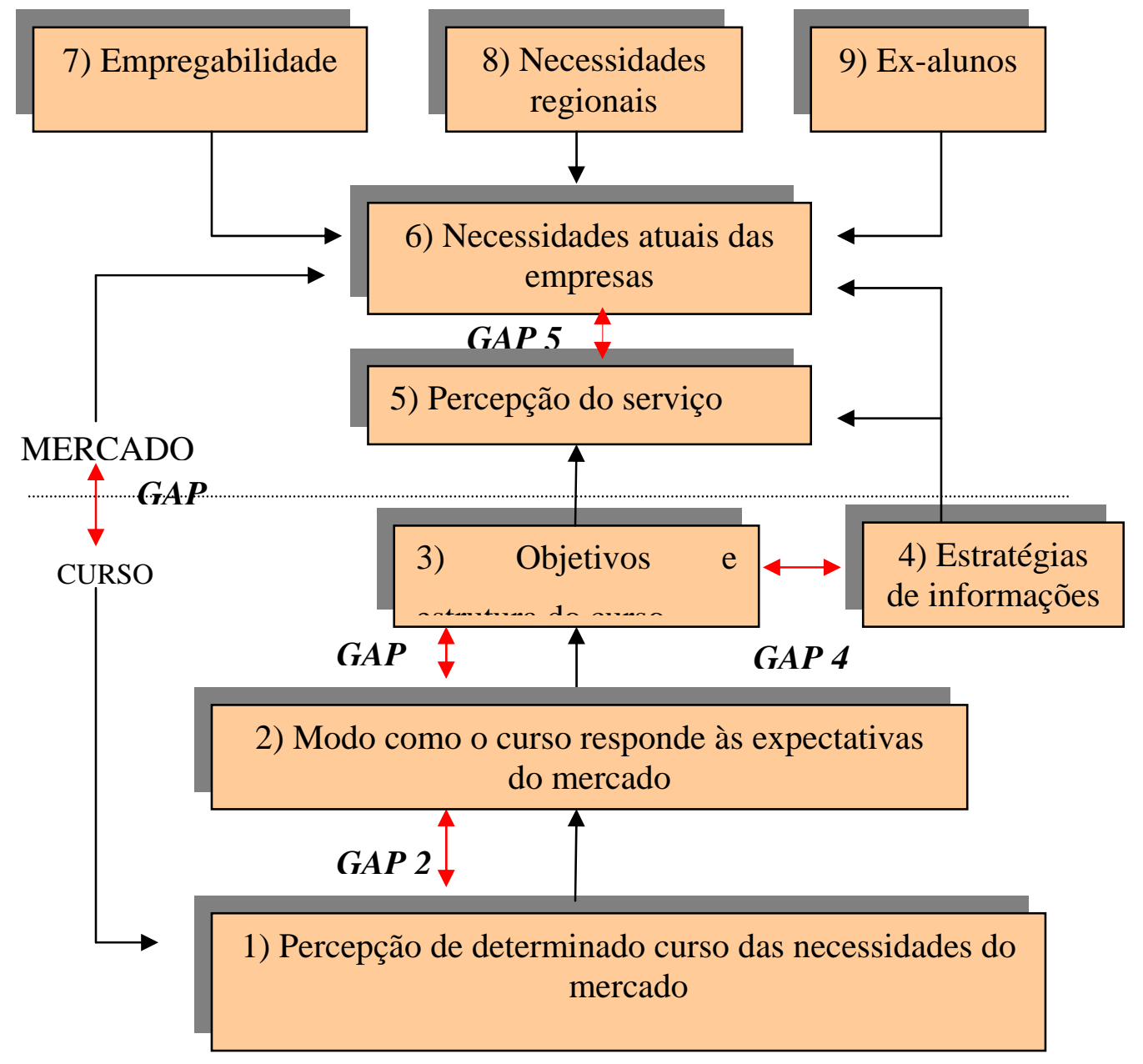

FIGURA 16. Adaptação do Modelo da Qualidade em Serviço de Parasuraman, Zeithalm \& Berry para o nível tático.

No nível tático, enfoca-se o mercado de trabalho e sua relação com a universidade e os cursos oferecidos uma vez que se faz necessário pensar em trabalho para que as pessoas sejam produtivas na economia de seu país. 
Assim como na figura anterior, será explicado cada item da Figura 16 para que, em seguida se possa fazer uma análise minuciosa dos gaps existentes entre cada ponto discutido.

1. Este campo refere-se à percepção de determinado curso oferecido pela universidade das necessidades do mercado, isto é, das demandas temporais. A universidade oferece cursos de engenharia uns mais antigos e outros recentes para atender um mercado em evolução e à própria universidade, além de cursos de extensão com carga horária de menor duração. Estes cursos apresentam uma estrutura que deve atender as necessidades e expectativas do mercado para que o profissional saia apto a desenvolver as habilidades e usar o conhecimento adquirido durante o curso.

2. Refere-se ao modo como determinado curso responde às expectativas do mercado de trabalho. Depois de medidas as expectativas e necessidades do mercado, esses cursos devem criar mecanismos para atender às expectativas e necessidades, formando profissionais aptos a trabalhar e desempenhar seu papel no mercado de trabalho.

3. Para atender as necessidades e expectativas do mercado de trabalho, deve haver uma estruturação do curso com o planejamento de aprendizagem e a delimitação de objetivos a serem alcançados. 
4. As estratégias de informações utilizadas pelos cursos e pela própria universidade que os oferece visa alcançar o máximo de profissionais e pessoas interessadas no conhecimento, desde a entrada de alunos pelo vestibular até programas de extensão e pós-graduação oferecidos a profissionais já encaminhados ao mercado, como forma de atualização contínua.

5. Diz respeito à percepção do serviço prestado em si pelo mercado de trabalho. O mercado de uma forma geral, vai comparar o que esperava com o que efetivamente recebeu. Faz isso, principalmente, através dos ex-alunos que contratou. Se eles forem bons profissionais, o serviço é bom, ao contrário não é.

6. Este item diz respeito à expectativa que o mercado de trabalho tem do atendimento de suas necessidades que está intimamente relacionado com os itens 7 , 8, e 9, isto é, com a empregabilidade dos profissionais formados pelo curso oferecido, dos ex-alunos e de suas necessidades regionais.

Depois de explicar cada item ou retângulo apresentado passa-se para a discussão nos gaps.

O gap1, no nível tático encontra-se entre a percepção de determinado curso das expectativas do mercado de trabalho. Pergunta-se: Essa expectativa é conhecida? Como essas necessidades são percebidas e atendidas? Está sendo medida antes de serem oferecidas disciplinas que tratem de sanar demandas temporais? De que forma é medida? 
O gap2, encontra-se entre a percepção do curso frente às necessidades do mercado de trabalho e ao modo como o curso responde a essas expectativas. Pergunta-se: Qual o seu papel? Qual a necessidade de atender as exigências do mercado de trabalho? Que tipo de serviço presta? Há um referencial por parte dos cursos para se tomar esse tipo de decisão? Como é feita a transformação das percepções em especificações?

O gap 3, diz respeito aos mecanismos que os cursos utilizam para repassar o conhecimento gerado, aos futuros profissionais, através dos próprios cursos ou palestras e da própria sala de aula. As aulas e os cursos estão atingindo seu objetivo ou precisam ser revistos?

No gap4 é preciso identificar quais as estratégias de marketing e informações que estão sendo utilizadas para que o mercado de trabalho tenha informações sobre o papel da universidade. Quais são os veículos? Estão sendo eficientes?

O gap5 é uma função dos outros gaps. A expectativa do serviço por parte do mercado, estará associada à empregabilidade e procura pelo serviço dos formandos, às necessidades regionais, isto é, as necessidades de cada região mercadológica deste mercado e às experiências passadas com ex-alunos que, se foram boas, o serviço está garantido. Como a empresa analisa a satisfação de suas necessidades? 


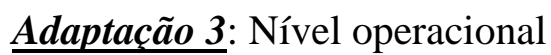

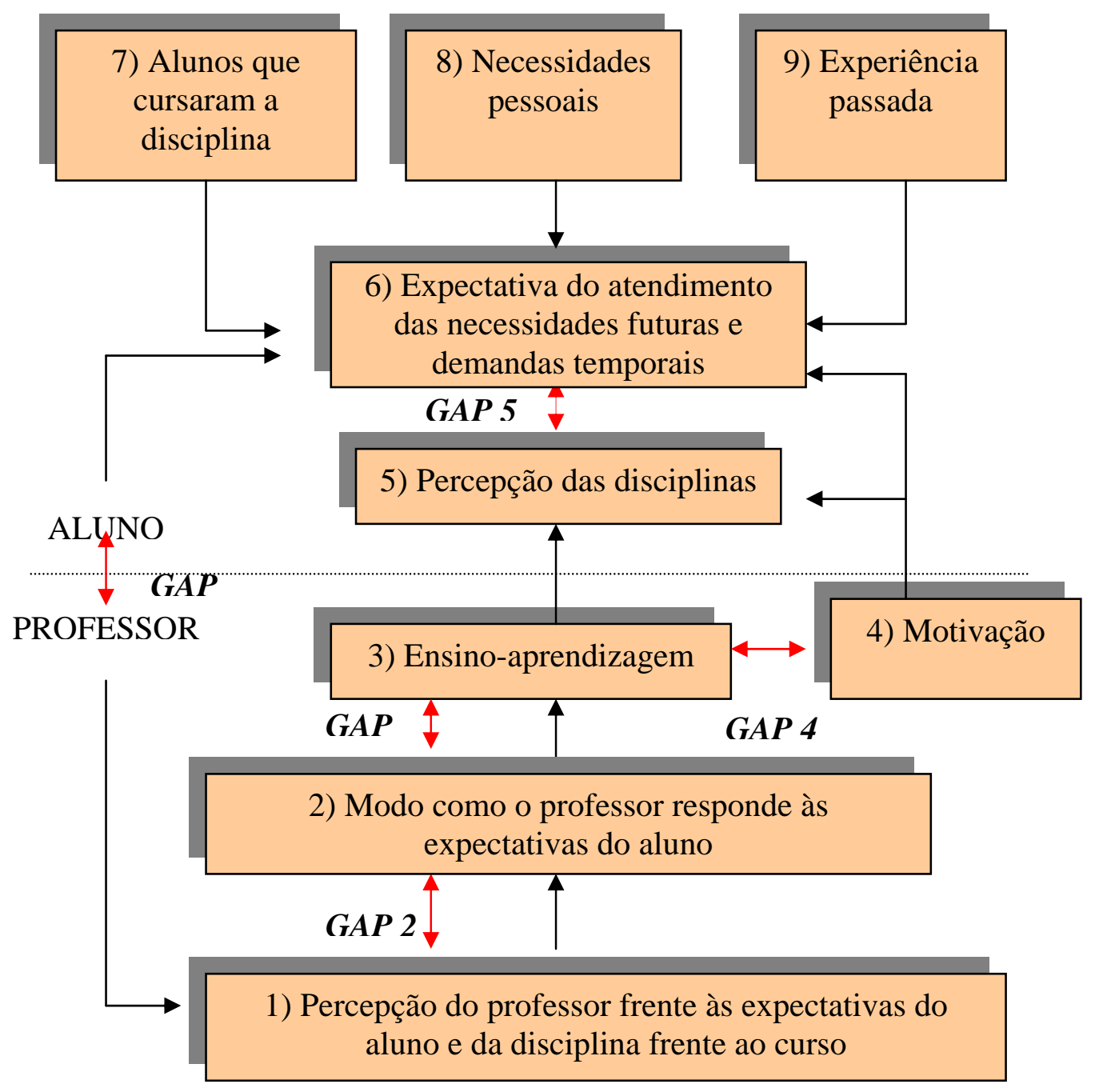

FIGURA 17. Adaptação do Modelo da Qualidade em Serviço de Parasuraman, Zeithalm \& Berry para o nível operacional.

Esta figura aponta as lacunas existentes no nível operacional que se dão diretamente através da relação professor aluno. 
Geralmente é neste ponto que surgem as maiores discussões relacionadas ao ensino e sua melhoria pois trata-se da relação em sala de aula.

1. Este item refere-se à percepção do professor frente às expectativas do aluno e da disciplina frente ao curso. É de fundamental importância que o professor conheça as expectativas do aluno e principalmente suas necessidades para que possa moldar a disciplina e se utilizar de metodologias que atinjam esse objetivo. Da mesma forma, a disciplina ministrada deve estar intrinsecamente ligada às necessidades do curso que conseqüentemente vai estar ligado às necessidades mercadológicas e sociais. O professor deve estar atento aos outros níveis para que possa atingir tanto os seus objetivos como os objetivos globais. Deve perceber que suas aulas e disciplina fazem parte de um todo maior e que não têm um fim em si mesmas.

2. Refere-se ao modo como o professor responde às expectativas dos alunos, como ele fará o planejamento de cada aula e da própria disciplina para atender a demanda. Deve levar em conta as diferenças individuais para que isso aconteça e também traçar objetivos comuns.

3. Este item diz respeito à própria atuação do professor e a forma como ele ministra as aulas. Neste item pensa-se nos objetivos e na própria estrutura do curso voltados a uma finalidade que é a de preparar o aluno para a sociedade e para o mercado de trabalho. 
4. Neste item, apontam-se as estratégias utilizadas para se atingir a demanda, isto é, a maneira como o professor motiva seus alunos e faz com que o conhecimento seja alcançado de maneira que não fuja às expectativas.

5. Este item trata da percepção da aula pelos alunos, da forma como estes alunos percebem a aula ministrada, sua importância e utilidade, além da própria disciplina. A forma como são motivados pelo professor tem grande peso neste item e também a forma como os outros alunos tratam a disciplina.

6. Há certa expectativa por parte dos alunos com relação à disciplina e as aulas para que atinjam suas necessidades, isto é, que atendam as necessidades futuras e demandas temporais dos alunos frente à sociedade e ao mercado de trabalho. Esta expectativa é criada em função de necessidades pessoais de cada um, de experiências passadas e da comunicação de ex-alunos da disciplina que fazem a comunicação boca a boca.

Depois da delimitação de cada campo, se faz necessário conhecer os gaps ou lacunas que se encontram nestes itens e que impedem, se desajustados, um alcance maior da qualidade.

O gap1 refere-se à percepção do professor frente às expectativas dos alunos. Essa expectativa existe? Deve ser levada em conta? Como é medida? Está de acordo com as necessidades dos outros clientes da educação, isto é, da sociedade e do mercado? O modo como o professor responde a essas expectativas está de acordo com a percepção? 
O gap2 diz respeito ao modo como o professor atende as necessidades dos alunos. Qual o seu papel? Que tipo de serviços presta? Qual o ponto de referência que o professor tem para tomar as suas decisões? Leva em conta os outros níveis? Existe algum tipo de restrição que impede o ajuste? Como é feita a transformação das percepções em especificações? Como é feito o planejamento do ensino?

O gap3 refere-se aos mecanismos que o professor utiliza para repassar o conhecimento gerado. O tipo de material didático, a metodologia de ensino e aprendizagem, os recursos didáticos. Essas estratégias estão sendo eficientes ou precisam ser revistas?

No gap4 é preciso identificar quais as estratégias que o professor tem utilizado para motivar os alunos, tornar a aula mais agradável. Quais são os veículos utilizados? Considerando a heterogeneidade dos alunos, os diferentes tipos de recursos, o objetivo está sendo atingido ou precisa ser revisto?

O gap5 é uma função dos outros gaps. Os alunos irão associar a aula com o que os alunos mais velhos falam da disciplina, com as experiências passadas de cada um e com as necessidades que eles apontam para sua formação. Assim, criam uma expectativa em função de suas necessidades.

Desta forma, esta estrutura pode ser adaptada às relações que de alguma forma colaboram para a qualidade do ensino de engenharia com a intenção de perceber os pontos falhos e procurar efetiva contribuição para sua melhoria e dentro de uma visão sistêmica, formar um quadro das diferentes ações que podem e devem ser tomadas (viáveis e desejáveis) para equacionar a questão da qualidade no ambiente acadêmico e posteriormente, na educação em engenharia. 
Através deste modelo, estas ações poderão se integrar em objetivos comuns e atingir resultados mais eficientes. Cada esfera, seja no nível estratégico, nível tático ou nível operacional não pode perder de vista os outros níveis e suas relações com o todo pois a qualidade deve ser encarada de forma global. 


\section{CONSIDERAÇÕES FINAIS}

Na tentativa de conseguir elementos para a compreensão da qualidade no processo educativo como um todo, consubstanciado no ensino de engenharia visto sob a ótica de serviços, pensou-se que a sistematização de um modelo de qualidade em serviços poderia sugerir formas de interpretar a realidade educacional uma vez que o atual não se faz eficiente face às novas exigências.

Surgiu a idéia deste modelo porque através dele a avaliação pode ser feita também durante o processo e não somente no final. A avaliação da qualidade do ensino através da qualidade dos resultados, isto é, do “produto” obtido ao fim da educação, é onerosa e descabida uma vez que não permite a intervenção durante o processo de formação.

O modelo como proposto, permite englobar todos os beneficiários e usuários da educação e todos os prestadores, e também identificar as ações a serem empreendidas pelo sistema educacional, bem como dos gaps que se originam quando há discrepâncias entre a percepção e a execução. Ao identificar os clientes (usuários), torna-se mais fácil atender as necessidades e expectativas dos beneficiários da educação, que ora é a sociedade, ora o mercado, ora os alunos. 
Passando por um breve histórico do ensino de engenharia, pelas suas características e mudanças atuais surge a necessidade de se repensar a prática educativa de uma forma que atinja tanto as necessidades futuras quanto às demandas temporais, isto é, as necessidades sociais e de mercado.

A preparação do engenheiro para atuar num mundo em constante mudança força a uma dinâmica inserção de novas competências essenciais no seu processo de formação, de modo que se viabilizem os desenvolvimentos da oferta de adequadas capacidades, no tempo certo.

Os novos conceitos sobre estratégias, a serem aplicados na formação do engenheiro, ao invés de estabelecerem uma estratégia estratificada, uma muralha impenetrável, devem conduzir ao desenvolvimento de mentes capazes de pensar estrategicamente, com a antecipação necessária, capazes de avaliar previamente o ambiente de atuação de suas empresas, fortalecendo os pontos fracos e valorizando e mantendo seus pontos fortes. EISENHARDT (1999), ressalta que a nova estratégia é essencialmente temporária, adaptável e complexa, o que exige uma atuação flexível, solidária, ritmada e integrada.

Essa nova atuação que começa a ser exigida passa a influir nas potencialidades funcionais do engenheiro e conseqüentemente deverá ser considerada no modelo educacional.

ROGERS (1978), afirma que o objetivo educacional deve tornar-se a facilitação de mudança e aprendizagem. Por este ponto de vista, o único homem educado é o homem que aprendeu a aprender, o homem que aprendeu a adaptar-se e a mudar, que percebe que nenhum conhecimento é seguro e que só o processo de 
buscar o conhecimento dá alguma base para a segurança. Somente indivíduos capazes de viver em equilíbrio delicado mas sempre mutável entre o que é atualmente conhecido e os fluentes móveis e mutáveis problemas e fatos do futuro atingirão o sucesso social.

Desta forma, novas alternativas vem sendo buscadas para se analisar o ensino de engenharia a fim de que isso possa trazer algumas contribuições para o foco em estudo. Quando se olha para o ensino através da ótica de serviços, muda-se a lente pela qual se analisa o processo educacional e assim, novos caminhos surgem. Centrase a atenção aos beneficiários do sistema, àqueles que utilizam o serviço prestado. Muda-se o foco do ensino para a aprendizagem.

O modelo proposto de qualidade em serviços permite uma análise global do ensino onde se pode olhar de forma holística todo o sistema educacional identificando as mudanças e as atuações em cada gap ou lacuna, que atinjam as necessidades dos beneficiários. A ênfase recai sobre o beneficiário da educação que, visto do ponto de vista operacional é o aluno e que também vai influenciar nos outros níveis uma vez que é o agente transformador no nível tático (mercado) e no nível estratégico (sociedade).

Quando se atua em uma das lacunas, esta ação está intrinsecamente refletida nas demais, uma vez que fazem parte de um sistema. Neste caso, olhando dentro do modelo, quando se propõe alguma mudança em sala de aula, esta ação estará intimamente ligada com o planejamento do curso, que estará voltado para as demandas temporais e as necessidades futuras, ligadas à sociedade. Há um vínculo 
que deve ser analisado levando todos os membros ligados ao ensino, à ação e a reflexão sobre a ação voltada para um objetivo maior.

Em cada nível são constatados pontos a serem discutidos.

No nível estratégico, a universidade deve agir conforme as necessidades da sociedade e não por ela mesma, por sua própria percepção do que é útil ou deixa de ser, uma vez que, desta forma, irá tomar ações em diferentes direções não atingindo os objetivos a que se propôs e se faz necessária. Através do modelo proposto, a universidade é capaz de fazer um diagnóstico das necessidades sociais e posteriormente criar mecanismos de ação a serem desempenhados para que desenvolvam as ações esperadas e com qualidade. A discussão da sua inserção regional ou nacional e das políticas e programas de investimento e de valorização podem ser visualizados neste nível de análise.

No nível tático, os cursos a serem ministrados devem se direcionar tanto para as necessidades sociais como para as necessidades de mercado. Se a universidade apresenta uma boa proposta após diagnosticar as necessidades e expectativas da sociedade mas não oferece cursos que possam efetivamente formar profissionais aptos, não terá excelência em qualidade na formação de seus alunos. A formação e treinamento da mão-de-obra já colocada no mercado podem ser uma das metas a se atingir. Neste nível é possível analisar a eficácia das ações empreendidas, inclusive com a incorporação de conhecimentos que atendam as necessidades da empresa e o modo como fazer.

No nível operacional a percepção do professor afeta a aula a ser ministrada e conseqüentemente o curso e o próprio papel da universidade. O professor não deve 
tornar-se obsoleto pois desta forma vai estar prejudicando a formação do aluno. Deve-se pensar em uma formação visando tanto à parte social, englobando ética e cidadania como a técnica criando habilidades como aprender a aprender. Necessidades de conhecimento em metodologia científica e didática são elementos a serem incluídos nas propostas de melhoria da educação. Este é um momento da verdade entre o aluno e o professor.

Como se pode observar, todos os níveis estão intimamente ligados, há relação de cada beneficiário ou prestador do serviço dentro de cada esfera e também entre elas. Se em cada retângulo e em cada lacuna, forem maximizados esforços que visem a qualidade, a situação da educação em engenharia atingirá efetiva melhoria em seus aspectos.

\subsection{Perspectivas Futuras}

Atualmente cresce a preocupação com a melhoria da qualidade do ensino de engenharia. Este é um fator que por si só permite novos estudos na linha de pesquisa apresentada.

Neste trabalho houve uma preocupação direcionada à elaboração de um modelo que permitisse analisar a qualidade do ensino de engenharia. O trabalho desenvolvido traz uma contribuição ao tema uma vez que propõe a sistematização de um modelo que permite analisar a qualidade do ensino de engenharia de forma global e não apenas propor ações fragmentadas, afastadas da realidade vista como um todo. 
Para alguns aspectos do fenômeno, a parte teórica serve apenas como guia e pode fornecer elementos para a reflexão. Torna-se, no entanto, necessário que posterior trabalho verifique estas relações na prática e ofereça mecanismos de melhoria uma vez que este trabalho limitou-se a aspectos teóricos.

A realização de pesquisas futuras se faz necessária no sentido de detalhar o modelo em cada um de seus níveis, criando estruturas que possam identificar as percepções e ações que visem a melhoria de qualidade da educação em engenharia. Outra possibilidade é aplicar o modelo de referência em casos concretos, em pesquisas de campo para validar a sua estrutura e verificar o que se faz e o que se pode fazer em cada gap ou lacuna existente entre os beneficiários do ensino e seus responsáveis uma vez que o papel da teoria é, muitas vezes, limitado.

Posteriormente, cada modelo e seus gaps podem ser minuciosamente estudados, de modo a gerar propostas de ações que possam efetivamente minimizar as discrepâncias existentes que afetam a qualidade da educação em engenharia. Isso será feito através de intensa pesquisa teórica e de campo.

É de se esperar também que novos materiais bibliográficos passem a estar disponíveis, pelo interesse que o tema vem despertando na comunidade científica, e esse fato permitirá novos embasamentos teóricos e conceituais que avançarão a discussão e proposição de ações de efetiva melhoria de qualidade na educação em engenharia. 
Este trabalho propõe-se a ser um desses novos materiais à disposição da comunidade preocupada com a educação de uma forma geral, que vá atender suas necessidades. 
ALBRECHT, K. (1992). Revolução nos serviços. São Paulo, Pioneira.

ALBRECHT, K; BRADFORD, L. J. (1992). Serviços com qualidade, a vantagem competitiva. São Paulo, Makron Books do Brasil.

ALMEIDA, P. N. (1973). O ensino globalizante em dinâmica de grupo. São Paulo, Saraiva.

BARREIRO, A.C. M. (1996) A Prática docente do professor de física do $3^{\circ} \mathbf{g r a u}$. São Paulo. 186p. Tese (Doutorado) - Faculdade de Educação, Universidade de São Paulo.

BAZZO, W.A.; PEREIRA, L. T. V. (1997). Introdução à engenharia. 5.ed. Florianópolis, UFSC.

BELHOT, R.V. (1997). Reflexões e propostas sobre o “ensinar engenharia” para o século XXI. São Carlos. 113p. Tese (Livre-docência)-Escola de Engenharia de São Carlos, Universidade de São Paulo.

- (1998). O ensino de engenharia sob o enfoque de serviços. In INTERNATIONAL CONFERENCE ON ENGINEERING EDUCATION, Rio de Janeiro, $\boldsymbol{C D}$ Room. Rio de Janeiro. 
. (1996). Introdução à teoria dos sistemas. São Carlos, EESC/USP. 76p. /Apostila/.

BRASIL. Secretaria do Ensino Superior. (1994) Programa de avaliação institucional das universidades brasileiras (PAUIB) /MEC/SESu. Brasília, Sesu.

CHIAVENATO, I. (1993). Teoria geral da administração. 4.ed. São Paulo, Makron Books.

COLENCI, A. T., BELHOT, R. V., COLENCI JR, A. (1998). O ensino de engenharia como uma atividade em serviços. CD Room. In: CONGRESSO BRASILEIRO DE ENSINO DE ENGENHARIA, 26; São Paulo.

COLENCI JR., A. et al. (1998). Elementos para uma revisão da atuação institucional, no âmbito do ensino superior do CEETEPS. São Paulo, /Monografia/.

(1996). Organizar as instituições para assegurar qualidade no ensino de engenharia. In: CONGRESSO BRASILEIRO DE ENSINO DE ENGENHARIA. 24; Anais. Manaus, ABENGE/Universidade do Amazonas.

(1994). The interrelation organization quality in the teaching of engineering. In: CONGRESSO INTERAMERICANO DE EDUCACIÓN EN INGENIERIA Y TECNOLOGIA. 4., Valencia, Proceedings. Valencia

DEMO, P. (1995). Desafios modernos da educação. 3.ed. São Paulo, Vozes. 
. (1997). Pesquisa, princípio científico e educativo. 5.ed. São Paulo, Cortez.

DIMENSTEIN, G. (1998). Qual será o perfil do trabalhador empregado no futuro? Folha de S. Paulo, São Paulo, 01/maio. Caderno Especial, p11.

DRUCKER, P.F. (1968). Uma era de descontinuidade: orientação para uma sociedade em mudança. São Paulo, Círculo do Livro.

EISENHARDT, K. \& BROWN, S. (1999). Competing on the Edge: Strategy as Structured Chaos. Harvard Business Scholl Press. USA

ELLENRIEDER, A. R. V. (1998) Administração em serviços: conceitos. Engenharia de Produção, n.1, p. 3-6.

ESCRIVÃO, E. F. (1998). Fundamentos de administração. In ESCRIVÃO , E. F. et al. Gerenciamento na construção civil. São Carlos/EESC/USP/Projeto Reenge.

FREIRE, P. (1974) Concientizacion. Buenos Aires, Busqueda. . (1975). Pedagogia do oprimido. Rio de Janeiro, Paz e Terra.

- (1996). Pedagogia da autonomia: saberes necessários à prática educativa. São Paulo, Paz e Terra. 
GARDNER, H. (1993). Inteligências múltiplas: a teoria na prática. Porto Alegre, Artes Médicas.

GIANESI, I.; CORREAA, H. (1994). Administração estratégica em serviços. São Paulo, Atlas.

GUILLON, A. B. B., MIRSHAWKA, V. (1994). Reeducação: qualidade, produtividade e criatividade: caminho para a escola excelente do século XXI. São Paulo, Makron Books.

KELLER, F. S. (1983). Psicologia. São Paulo, Ática.

KURI, N. P. (1990). O Ensino das disciplinas com altos índices de reprovação no curso de engenharia: aspectos metodológicos. São Carlos, 218p. Dissertação (mestrado), Centro de Educação e Ciências Humanas, Universidade Federal de São Carlos.

LABEGALINI, P. R. (1997). O papel do professor universitário na qualidade de serviço. São Paulo, 211p. Tese (Doutorado)-Escola Politécnica, Universidade de São Paulo.

LAS CASAS, A. L. (1994). Qualidade total em serviços: conceitos, exercícios e casos práticos. São Paulo, Atlas.

LEVITT, T. (1984) Administração de serviços. In: KOTLER, P. Administração de marketing. São Paulo, Atlas. 
MELLO, G. N. (1998). Cidadania e competitividade: desafios educacionais do terceiro milênio. 7.ed. São Paulo, Cortez.

MENDES, G. H. S. (1998). O processo de desenvolvimento de novos serviços: o setor bancário. São Carlos. 165p. Dissertação (Mestrado) - Engenharia de Produção, Universidade Federal de São Carlos.

MINICUCCI, A. (1982). Dinâmica de grupo: teorias e sistemas. São Paulo, Atlas.

MIZUKAMI, M. G. N. (1983). Ensino: o que fundamenta a ação docente? Um estudo de abordagens do processo ensino-aprendizagem. Tese (Doutorado)Pontífica Universidade Católica do Rio de Janeiro.

. (1986). Ensino: abordagens do processo. Temas básicos de educação e Ensino. São Paulo. EPU.

NÉRICI, I. G. (1969). Metodologia do ensino superior. São Paulo, Fundo de Cultura.

PARASURAMAN, A.; BERRY, L. L. (1991). Understanding customer expectations of service. USA. Sloan Management Review.

PLONSKY, G. A. (1993). Engenharia, engenharias e reengenharia. Revista Politécnica n. 211. p.14-15.

PORFÍRIO, M. (1992). Metodologia do projecto tecnológico. Lisboa, Universidade Aberta.

PUENTE, M. (1978). O Ensino centrado no estudante. São Paulo, Cortez. 
REBELATO, M. G. (1995). A Qualidade em serviços: uma revisão analítica e uma proposta gerencial. São Carlos. 148p. Dissertação (Mestrado) - Escola de Engenharia de São Carlos, Universidade de São Paulo.

REBELATTO, D. A. N. (1999). O Campo de atuação profissional do engenheiro de produção: inter-relações com as áreas de economia e finanças. São Carlos. 171p. Tese (Doutorado) - Escola de Engenharia de São Carlos, Universidade de São Paulo.

RIVAS, T. (1998). As tecnologias colaborativas em ambiente distribuído de aprendizagem como um recurso de formação continuada do engenheiro de produção. Dissertação (Mestrado) - Escola de Engenharia De São Carlos, Universidade de São Paulo.

ROGERS, K. (1978). In MILHOLLAN, F. Skinner $\boldsymbol{X}$ Rogers: maneiras constantes de encarar a educação. 4.ed. São Paulo, Summus.

RONCA, A. C. C. (1984). Técnicas pedagógicas. Petrópolis. Vozes.

RUIZ, S. (1998). Como se preparar para o que der e vier. Folha de São Paulo, São Paulo, 5 out. Folhateen, p 5.

SACADURA, J. F. (1999). A formação do engenheiro no limiar do terceiro milênio. In: LINSENGEN, I.V. et al. (1999). Formação do engenheiro: desafios da atuação docente, tendências curriculares e questões da educação tecnológica. Florianópolis, UFSC. p. 13-27. 
SCHULTZ, D. P.; SCHULTZ, S. E (1992). História da psicologia moderna. 8.ed. São Paulo, Cultrix.

SENGE, P. M. (1990). A Quinta disciplina. 5.ed. São Paulo. Círculo do Livro.

SILVA, J. R. (1997). Uma definição formal para engenharia. Revista de Ensino de Engenharia - ABENGE; n. 17, p. 11-18.

SIRVANCI, M. (1996). Are students the true customers of higher education? Quality progress. p. 99 a 102. Oct.

SMYSER, B. M. (1995). Active and Cooperative Learning. http://www.wpi.edu/ isg_501/bridget.html. 10 jan.

TELLES, P. C. S. (1984). História da engenharia no Brasil. Rio de Janeiro, LTC Livros Técnicos e Científicos.

TOFLER, A. (1980). A terceira onda - o fim do industrialismo. Trad. por João Távora. 15. ed. Rio de Janeiro, Record.

UNIVERSIDADE FEDERAL DE MINAS GERAIS. (1982). Indicadores da qualidade no ensino: uma proposta. In: A PROPÓSITO da qualidade do ensino superior no Brasil: anais de dois encontros. Brasília, Ministério da Educação e Cultura.

UNI. UNIVERSITY OF NORTHERN IOWA. (1998). Active, cooperative and experimental learning. http://www.uni.edu/teachctr/active.html. 10. jan. 
ZEITHAML, V.A.; PARASURAMAN, A.; BERRY, L.L. (1990). Delivering service quality: balancing customer perceptions and expectations. New York, The Free Press.

MANUAL de avaliação SECAI. (1993).Brasília. CRE-Columbus.

The MALCON baldrige national quality award. (1995). Education pilot program. Milwaukee. American Society for Quality Control. 
BRASIL. Ministério da Educação. Secretaria da Educação Superior. (1988). Avaliação do ensino superior. In: Encontro Internacional. Brasília.

BAILEY, D. BENNETT, J. V. (1996). The Realistic model of higher education. Quality Progress, october.

BEMOWSKI, K. (1991). Restoring the pillars of higher education. Quality Progress, october.

BERVIAN, P.A.; CERVO, A.L..(1996). Metodologia científica. São Paulo, Makron.

DAHLGAARD, J. J., KRISTENSEN, K, KANJI, G. K. (1995). Total quality management and Education. Total Quality Management, vol. 6.

FLEURY, M.T.L. (1995). Aprendendo a mudar, aprendendo a aprender. Revista de Administração. v. 30, n. 3, p. 5-11.

FREITAG, A. (1994). Análise crítica das políticas de educação superior no Brasil. Revista Dois Pontos: Lê, n. 19. 
KARAPETROVIC, S. RAJAMANI, D. (1998). An Approach to the application of statistical quality control techniques in engineering courses. Journal of Engineering Education.

ROGERS, K. (1986). Liberdade de aprender em nossa década. 2. ed. Porto Alegre, Artes Médicas.

SPANBAUER, S. J. (1995). Reactivanting higer education with total quality management: using quality and productivity concepts, techniques and tools to improve higher education. Total quality management, vol. 6.

THIOLLENT, M. (1994). Metodologia da pesquisa-ação. São Paulo, Cortez. 